\title{
India: Domestic Issues, Strategic Dynamics, and U.S. Relations
}

\author{
K. Alan Kronstadt, Coordinator
}

Specialist in South Asian Affairs

Paul K. Kerr

Analyst in Nonproliferation

Michael F. Martin

Specialist in Asian Affairs

Bruce Vaughn

Specialist in Asian Affairs

September 1, 2011 


\section{Summary}

South Asia emerged in the $21^{\text {st }}$ century as increasingly vital to core U.S. foreign policy interests. India, the region's dominant actor with more than one billion citizens, is often characterized as a nascent great power and "indispensable partner" of the United States, one that many analysts view as a potential counterweight to China's growing clout. Since 2004, Washington and New Delhi have been pursuing a "strategic partnership" based on shared values and apparently convergent geopolitical interests. Numerous economic, security, and global initiatives, including plans for civilian nuclear cooperation, are underway. This latter initiative-first launched in 2005 and codified in U.S. law in 2008 - reversed three decades of U.S. nonproliferation policy, but has not been implemented to date. Also in 2005, the United States and India signed a ten-year defense framework agreement to expanding bilateral security cooperation. The two countries now engage in numerous and unprecedented combined military exercises, and major U.S. arms sales to India are underway. The value of all bilateral trade tripled from 2004 to 2008 and continues to grow; significant two-way investment also flourishes. The influence of a large, relatively wealthy, and increasingly influential Indian-American community is reflected in Congress's largest countryspecific caucus. More than 100,000 Indian students are attending American universities.

Further U.S. attention on South Asia focuses on ongoing, historically rooted tensions between India and Pakistan. In the interests of regional stability, in particular as a means of facilitating U.S.-led efforts to stabilize nearby Afghanistan, the United States strongly endorses an existing, but largely moribund India-Pakistan peace initiative, and remains concerned about the potential for conflict over Kashmiri sovereignty to cause open hostilities between these two nuclear-armed countries. The United States also seeks to curtail the proliferation of nuclear weapons and missiles in South Asia.

President Barack Obama's Administration has sought to build upon the deepened U.S. engagement with India begun by President Bill Clinton in 2000 and expanded upon during much of the past decade under President G.W. Bush. This "U.S.-India 3.0" diplomacy was most recently on display in July 2011, when the second U.S.-India Strategic Dialogue session saw a large delegation of senior U.S. officials visit New Delhi to discuss a broad range of global and bilateral issues. Many analysts view the U.S.-India relationship as being among the world's most important in coming decades and see potentially large benefits to be accrued through engagement on many convergent interests. Bilateral initiatives are underway in all areas, although independent analysts in both countries worry that the partnership has lost momentum in recent years. Outstanding areas of bilateral friction include obstacles to bilateral trade and investment, including in the high-technology sector; outsourcing; the status of conflict in Afghanistan; climate change; and stalled efforts to initiate civil nuclear cooperation.

India is the world's most populous democracy and remains firmly committed to representative government and rule of law. Its left-leaning Congress Party-led ruling national coalition has been in power for more than seven years under the leadership of Prime Minister Manmohan Singh, an Oxford-trained economist. New Delhi's engagement with regional and other states is extensive and reflects its rising geopolitical status. The national economy has been growing rapidlyIndia's is projected to be the world's third-largest economy in the foreseeable future-yet poor infrastructure, booming energy demand, and restrictive trade and investment practices are seen to hamper full economic potential. Despite the growth of a large urban middle-class, India's remains a largely rural and agriculture-based society, and is home to some 500-600 million people living in poverty. This report will be updated periodically. 


\section{Contents}

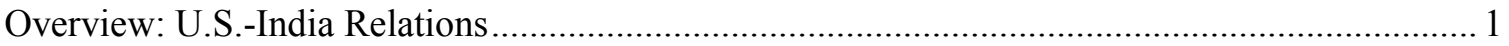

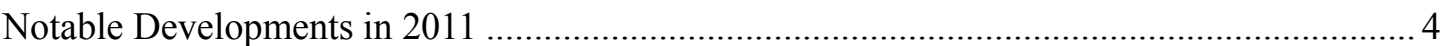

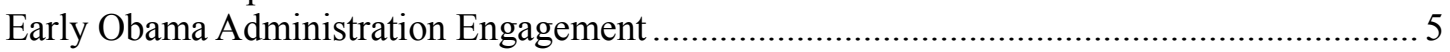

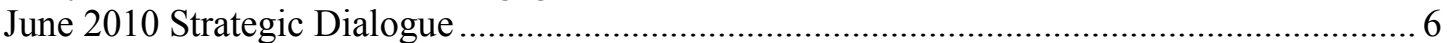

President Obama's November 2010 Visit to India ............................................................... 7

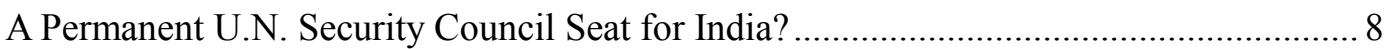

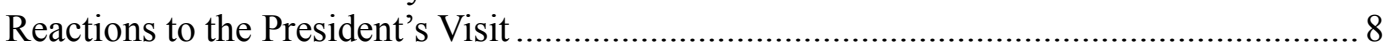

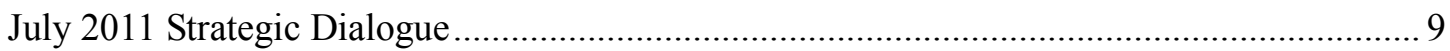

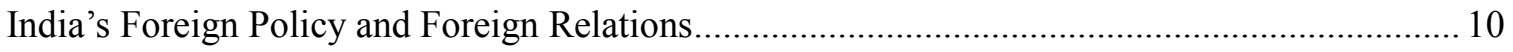

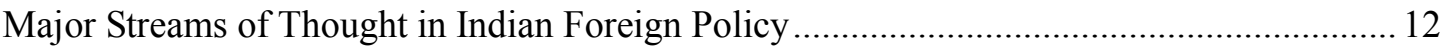

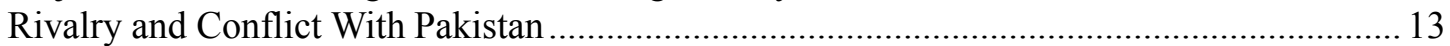

The India-Pakistan Peace Process ............................................................................... 14

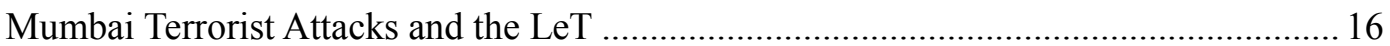

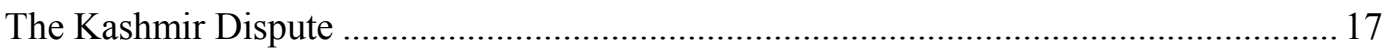

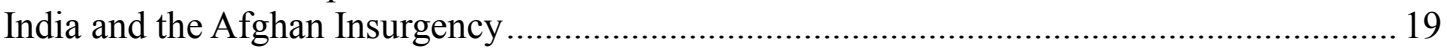

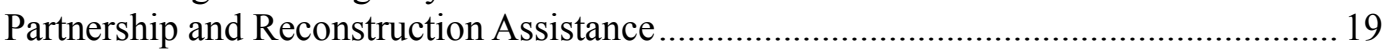

Afghan Reconciliation, Security Concerns, and the U.S. Drawdown............................. 19

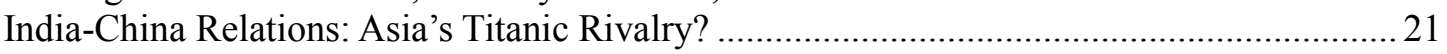

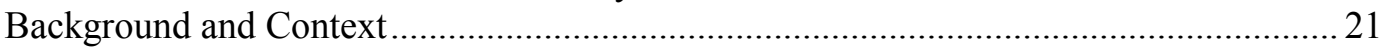

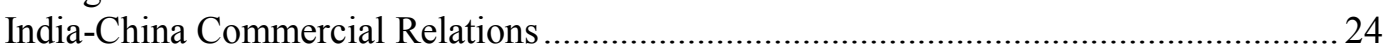

Is There a Chinese "String of Pearls" Strategy in the Indian Ocean? ............................... 24

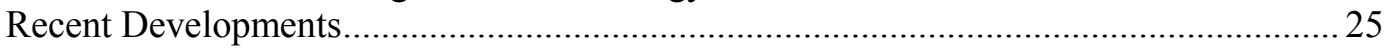

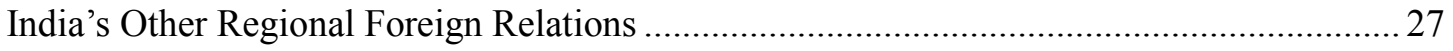

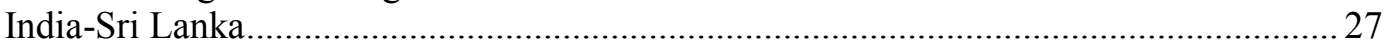

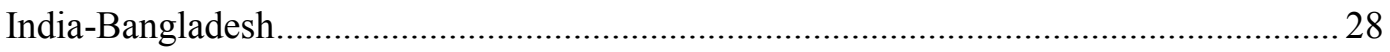

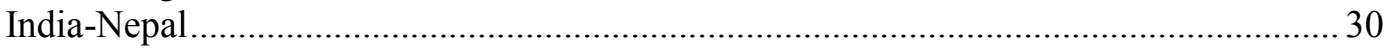

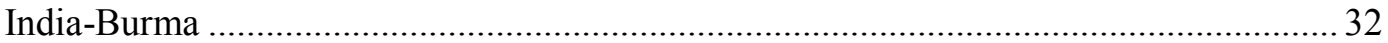

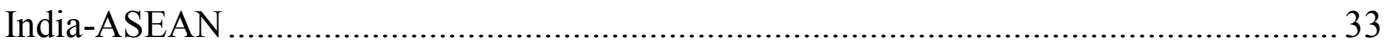

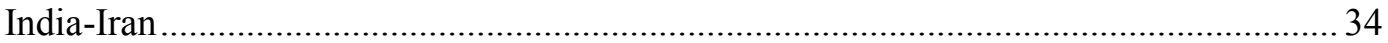

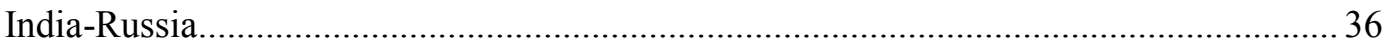

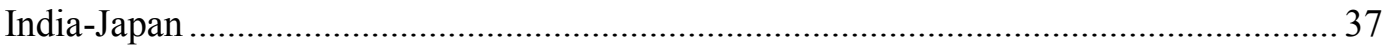

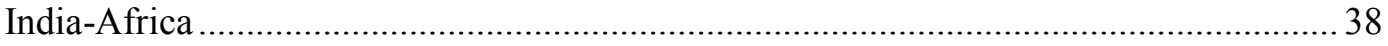

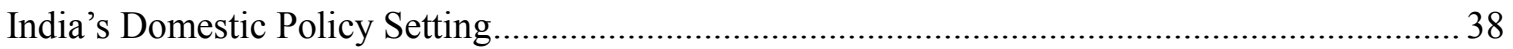

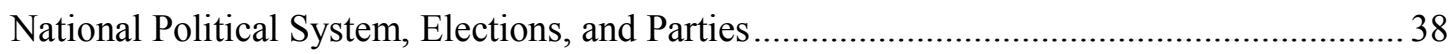

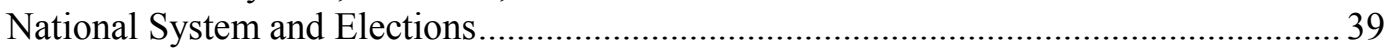

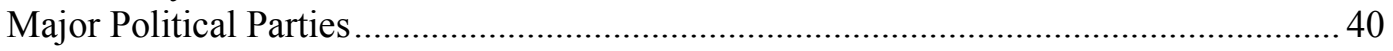

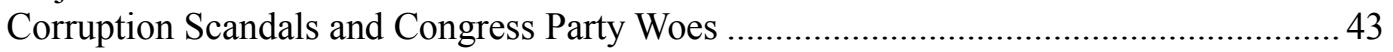

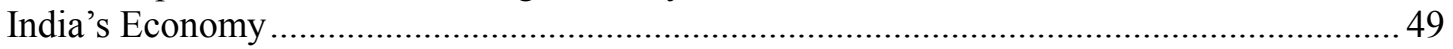

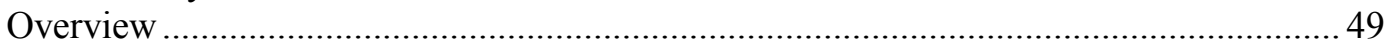

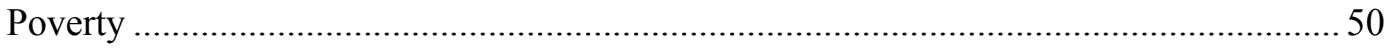

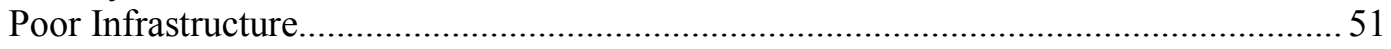

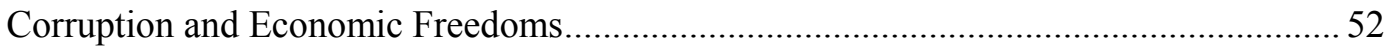

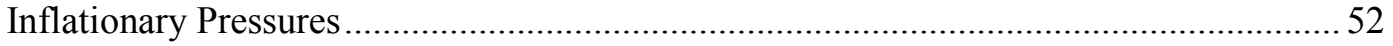

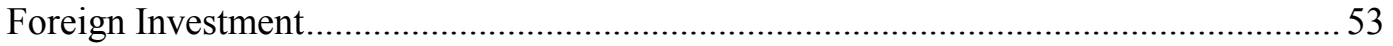

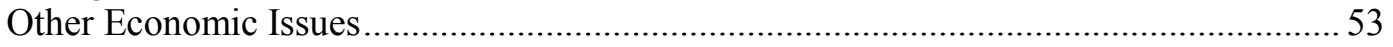

India's Energy, Environment, and Climate Change Policies ................................................. 54 


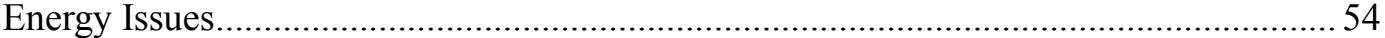

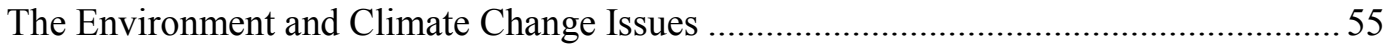

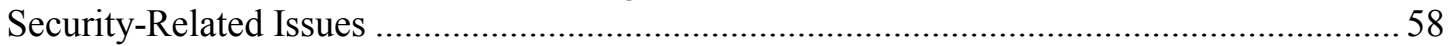

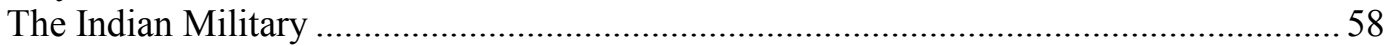

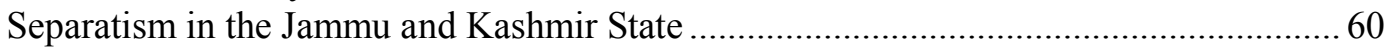

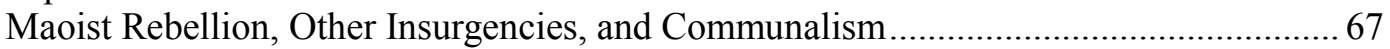

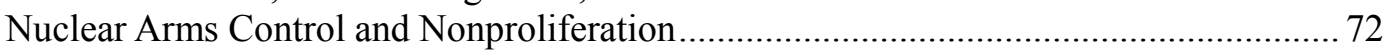

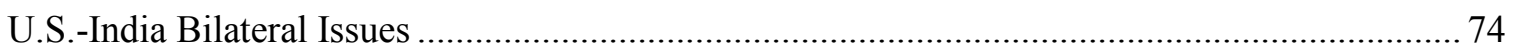

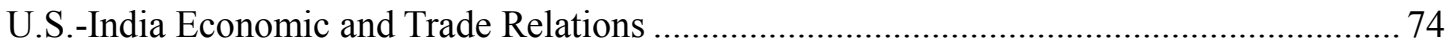

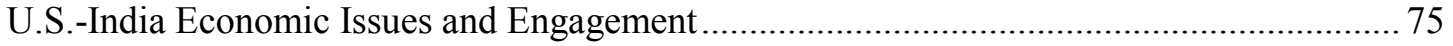

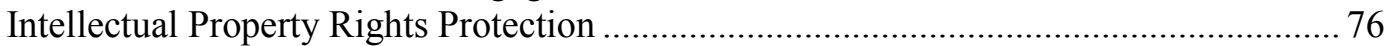

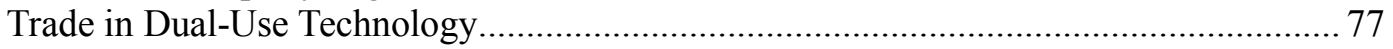

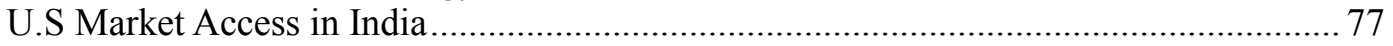

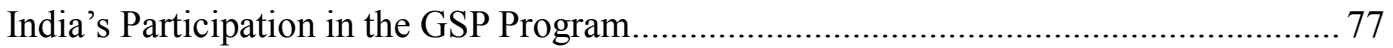

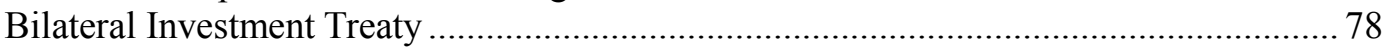

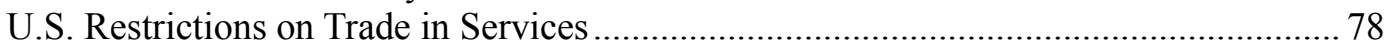

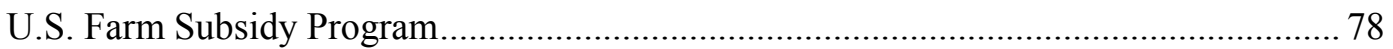

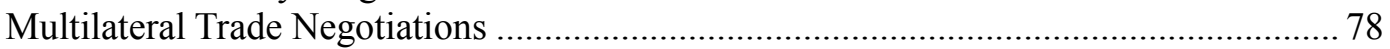

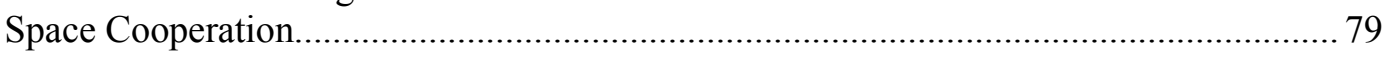

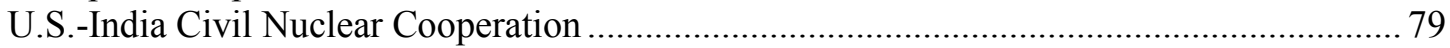

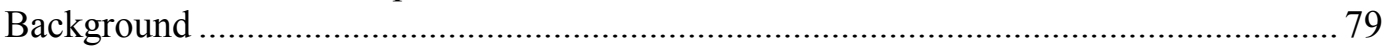

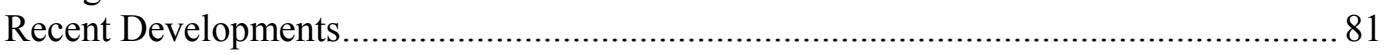

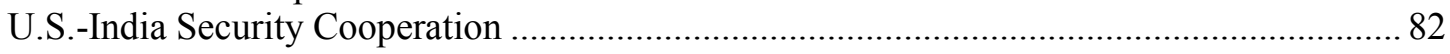

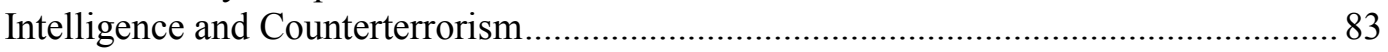

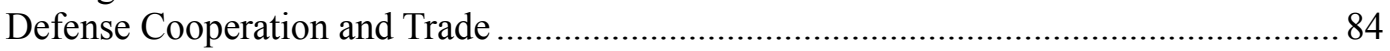

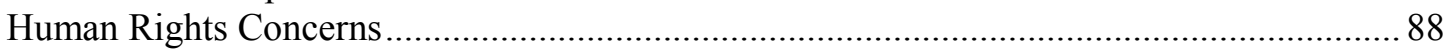

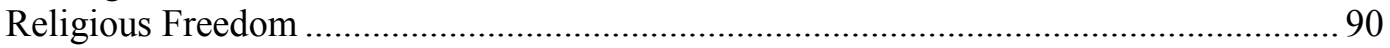

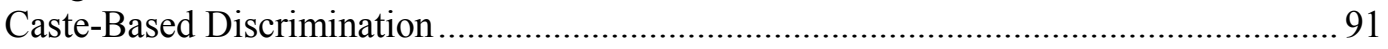

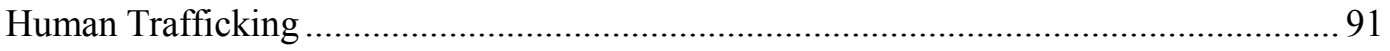

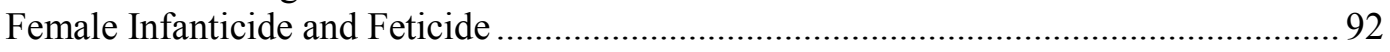

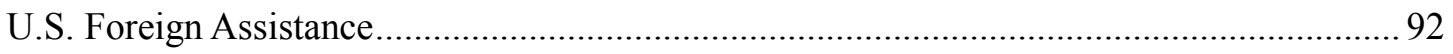

\section{Figures}

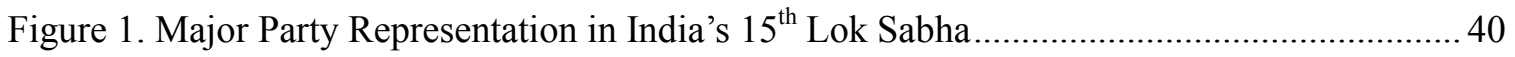

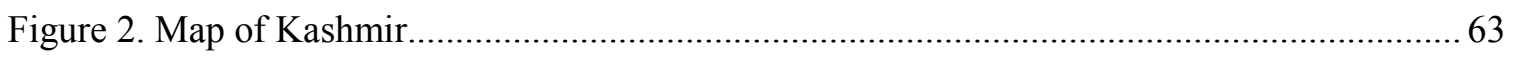

Figure 3. Deaths Related to Kashmiri Separatist Conflict, 1988-2010 ........................................ 64

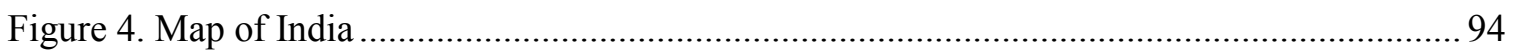

\section{Tables}

Table 1. Direct U.S. Assistance to India, FY2001-FY2011 .

\section{Contacts}

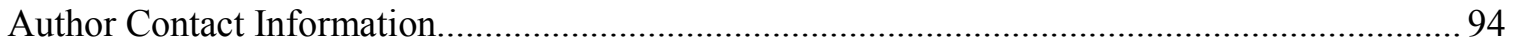




\section{Overview: U.S.-India Relations}

The United States does not just believe, as some people say, that India is a rising power; we believe that India has already risen. India is taking its rightful place in Asia and on the global stage. And we see India's emergence as good for the United States and good for the world. -President Barack Obama, Mumbai, India, November 7, $2010^{1}$

With the lifting of Cold War geopolitical constraints and the near-simultaneous opening of India's economy in early 1990s, the world's largest democracy has emerged as an increasingly important player on the global stage. India dominates the geography of the now strategically vital South Asia region, and its vibrant economy, pluralist society, cultural influence, and growing military power have made the country a key focus of U.S. foreign policy attention in the $21^{\text {st }}$ century. This attention is to some degree motivated by China's longer-standing and more rapid rise, with many analysts viewing U.S. and Indian geopolitical interests as convergent on many fronts, perhaps especially in the area of Asian power balances. President George W. Bush is credited with building on the breakthrough visit by President Bill Clinton in 2000, which ended the estrangement of the post-1998 Indian nuclear weapons tests. Under President Bush and continuing with President Barack Obama the U.S. and Indian governments have been seeking to sustain a substantive "strategic partnership," even as bilateral commercial and people-to-people contacts flourish of their own accord.

The U.S.-India partnership is based on shared values such as democracy, pluralism, and rule of law. Numerous economic, security, and global initiatives, including unprecedented plans for civilian nuclear cooperation, are underway. The two countries inked a ten-year defense framework agreement in 2005 to facilitate expanded bilateral security cooperation. In the new century, large-scale combined military exercises have become commonplace, and bilateral cooperation on intelligence and counterterrorism is increasing. Unprecedented major U.S. arms sales to India are underway; more are anticipated. The influence of a geographically dispersed and relatively wealthy Indian-American community of some 2.7 million is reflected in Congress's largest country-specific caucus. More than 100,000 Indian students are attending American universities. Notably, a number of Indian-Americans now occupy senior positions in the Obama Administration, Agency for International Development Administrator Rajiv Shah among them. ${ }^{2}$

Further U.S. interest in South Asia focuses on ongoing tensions between India and Pakistan rooted largely in competing claims to the Kashmir region and in "cross-border terrorism" in both Kashmir and major Indian cities. In the interests of regional stability, in particular as a means of forwarding U.S. interests in nearby Afghanistan, the United States strongly endorses an existing, but until recently moribund India-Pakistan peace initiative, and remains concerned about the

\footnotetext{
1 "Remarks by the President and First Lady in Town Hall With Students in Mumbai, India," White House release, November 7, 2010.

2 "Desis in DC," Times of India (Delhi), December 19, 2009. According to India's Ambassador to the United States, America is home to 50,000 Indian-born physicians, and 10,000 Indian-American hotel and motel owners who employ nearly 600,000 people; some 40\% of American hotel rooms are owned by Indian-Americans. A Newsweek article claims that two-thirds of people of Indian descent living in America have a college degree, compared to less than onethird of the general population, and the average household income is $\$ 90,000$ for ethnic Indians as compared to $\$ 50,000$ for all U.S. households (Embassy of India, "Ambassador's Address at the 'People-to-People' Conference," October 28, 2010; "India Conquers the World,” Newsweek, July 25, 2011).
} 
potential for conflict over Kashmiri sovereignty to cause open hostilities between these two nuclear-armed countries. The United States also seeks to curtail the proliferation of nuclear weapons and missiles in South Asia.

President Obama desires to continue expanded engagement and cooperation with India. His May 2010 National Security Strategy noted that, "The United States and India are building a strategic partnership that is underpinned by our shared interests, our shared values as the world's two largest democracies, and close connections among our people." "Yet there are concerns among observers in both countries that momentum has waned (by some accounts due to U.S. inattention), that outstanding areas of friction continue to hinder optimal levels of cooperation, and that India's geostrategic, economic, and security circumstances combine with New Delhi's lingering skepticism over America's global and regional role to preclude the kind of "special relationship" that many boosters of U.S.-India ties envisage. While U.S.-India engagement under the Obama Administration has not (to date) realized any groundbreaking initiatives as was the case under the Bush Administration, it may be that the apparently growing "dominance of ordinariness" in the relationship is a hidden strength that demonstrates its maturing into diplomatic normalcy. ${ }^{4}$

Indeed, there is a pervasive sense in policy circles that dramatic new breakthroughs in U.S.-India relations are not on the horizon, and that President Obama's November 2010 travel to India may have brought the two countries to a plateau of sorts whereupon routinized, but still meaningful interactions take place in the near term. Both national governments have been dealing with serious domestic issues in 2011 (the United States with federal budget issues, India with major corruption scandals), as well as with more pressing foreign policy concerns.

\footnotetext{
${ }^{3}$ The document continues: "Working together through our Strategic Dialogue and high-level visits, we seek a broadbased relationship in which India contributes to global counterterrorism efforts, nonproliferation, and helps promote poverty-reduction, education, health, and sustainable agriculture. We value India's growing leadership on a wide array of global issues, through groups such as the G-20, and will seek to work with India to promote stability in South Asia and elsewhere in the world" (see http://www.whitehouse.gov/sites/default/files/rss_viewer/ national_security_strategy.pdf).

${ }^{4}$ Ashley Tellis, "Manmohan Singh Visits Washington: Sustaining U.S.-Indian Cooperation and Differences," Carnegie Endowment for International Peace Policy Brief 85, November 2009. See also Ronen Sen, "From Drama to Routine" (op-ed), Telegraph (Kolkata), July 28, 2011.
} 
Given a setting in which the private sectors of both countries are impatient with the pace of economic reform in India and with rampant corruption there, some analysts call on the two governments to concentrate on limited goals with clear chances for success, such as in defense trade and with the development of multilateral and Asian architectures, in both the economic and security realms. ${ }^{5}$ One leading Indian commentator urges American patience and recognition that New Delhi views engagement with the United States as its highest foreign policy priority. The contention here is that India's four purported top long-term foreign policy objectives - a stable Afghanistan-Pakistan region; exerting influence across the Indian Ocean region; obtaining status as a "rule-maker" in the international system; and strengthening "global power" factors such as sustained economic growth and military modernization - all require strategic cooperation with the United States. ${ }^{6}$ Yet a more pessimistic view has the bilateral relationship constrained in large part by differences over the U.S.-Pakistan alliance and by India's apparent reluctance to exert power in its own region, resulting in years of "a lot of rhetoric but very little substantive movement" in U.S.-India ties. ${ }^{7}$

The sweeping scope of the bilateral relationship, as well as the perceived lack of focus within it, may be found in the various and usually large number of issue-areas listed in joint statements. However, in May 2011, the lead U.S. diplomat for the region helpfully summarized U.S.-India relations under the rubric of four major "agendas":

- an innovation agenda that includes collaboration on energy security, civil nuclear cooperation, agriculture, space, climate, and other sciences;

- a security agenda that includes military-to-military relations, arms sales, and nonproliferation;

- a people-to-people agenda that encourages civic engagement, and open governance and democracy initiatives; and

- a growth agenda focused on increasing bilateral trade and investment by removing barriers to both. ${ }^{8}$

\footnotetext{
${ }^{5}$ See S. Amer Latif and Kart Inderfurth, "Six Months After the Obama-Singh Summit," CSIS U.S.-India Insight, June 2011. The United States and India have since 2007 participated in an East Asia Dialogue, and the two countries have since expanded strategic consultation with June 2011 the launching of a Central Asia Dialogue and the subsequent July launch of a West Asia Dialogue. Plans to open consultations on Latin America and the Caribbean are underway. In 2011, the United States is inviting India to join the upcoming Asia Pacific Economic Cooperation summit in Hawaii as an observer country (India's membership in APEC is not possible at present).

${ }^{6}$ C. Raja Mohan, "India's Strategic Future," Foreign Policy (online), November 4, 2010. See also Daniel Twining and Richard Fontaine, "The Ties that Bind?: U.S.-Indian Values-Based Cooperation," Washington Quarterly, Spring 2011.

${ }^{7}$ Harsh Pant, "The Chasm Between India and the U.S." (op-ed), Wall Street Journal, July 24, 2011. See also Dhruva Jaishankar, "U.S.-India Relations: Can India Step Up to the Plate?," East-West Center Asia Pacific Bulletin 126, August 2, 2011.

${ }^{8}$ Assistant Secretary of State Robert Blake, "The Current State of U.S.-India Cooperation and Prospects for the Future (As Prepared)" (speech transcript), Department of State release, May 13, 2011. President Obama's November 2010 state visit to India produced summaries of 16 major issue-areas for bilateral cooperation: (1) Export controls, to include U.S. support for India's membership in major export control regimes; (2) Trade and economic cooperation with a shared commitment to open market economics; (3) Partnership for an Evergreen Revolution that will focus on enhancing India's food security through enhanced weather and climate forecasting, and with improved food processing and food-to-market links; (4) Counterterrorism cooperation building on a landmark July 2010 initiative; (5) Civil space cooperation, including space exploration and earth observation; (6) Clean energy and climate change, to ensure mutual energy security and build clean energy economies; (7) Cybersecurity and the promotion of reliable information and communication infrastructures; (8) The CEO Forum and implementation of its recommendations; (9) Defense cooperation through extensive military-to-military links, joint exercises, defense sales, and a focus on coordinating (continued...)
} 
Tangible progress is being made in each of these areas despite ongoing U.S. government irritants, in particular obstacles to full implementation of civil nuclear cooperation; overly restrictive limits on foreign investment; lingering barriers to trade; and insufficient protection of intellectual property rights, among others. Even leading American boosters of expanded U.S.-India ties insistently call on New Delhi to take more rapid action in these areas. ${ }^{9}$

\section{Notable Developments in 2011}

- U.S.-India cooperation in the area of nuclear energy - an initiative launched in 2005 and approved by Congress in 2008 — continues to be delayed by the lack of both a liability arrangement and an agreement on monitoring arrangements for U.S. nuclear exports to certain Indian entities (see the "U.S.-India Civil Nuclear Cooperation" section below).

- In April, New Delhi announced that it had narrowed the list of competitors for a roughly $\$ 11$ billion contract for 126 new medium multi-role combat aircraft (MMRCA) to two finalists, both European vendors. U.S. government officials expressed being "deeply disappointed" by news of the "deselection" of U.S.based Boeing and Lockheed Martin from consideration, and what seemed a choice with major geostrategic implications elicited much debate over its meaning (see the "Defense Cooperation and Trade" section below). ${ }^{10}$

- Major corruption scandals that broke in New Delhi in late 2010 have snowballed into a crisis not only for the sitting Congress Party-led United Progressive Alliance national coalition government, but also for India's political system writ large. Summer months have seen the emergence of a massive people's movement protesting the country's pervasive corruption, a movement lead in particular by social activist Anne Hazare (see the "Corruption Scandals and Congress Party Woes" section below).

- U.S. Ambassador to India Tim Roemer tendered his resignation on April 28, 2011, the same day that New Delhi announced the MMRCA deselection, and departed the New Delhi post on June 30. Roemer explained his departure as arising for personal, professional, and family reasons. The interim Chief of Mission, Peter Burleigh, is a highly competent veteran American diplomat with significant regional experience, but observers warn that U.S.-India relations

(...continued)

efforts to ensure maritime security; (10) The U.S.-India Economic and Financial Partnership that institutionalizes deeper bilateral relations in economic and financial sectors; (11) Education, including academic exchanges, university linkages, and the holding of a U.S.-India Education Summit; (12) Nuclear security, including cooperative activities with India's Global Center for Nuclear Energy Partnership; (13) Deepening U.S-India strategic ties through greater consultation on foreign policy issues of mutual concern; (14) Development collaboration in Afghanistan, with a focus on agricultural development and women's empowerment; (15) Securing the air, sea, and space domains that transcend national borders; and (16) Open government dialogue based on shared interest in democracy and transparency (see "The U.S.-India Partnership: The Fact Sheets," White House release, November 8, 2010).

${ }^{9}$ See, for example, Richard Armitage and Nicolas Burns, “A To-Do List for Obama in India” (op-ed), Wall Street Journal, November 5, 2010.

${ }^{10}$ Department of State release, April 29, 2011. 
could suffer if the Obama Administration does not move quickly to appoint a new permanent Ambassador. ${ }^{11}$

- In June, Ranjan Mathai, a career foreign service office and former ambassador to France, was appointed to replace Nirupama Rao as Indian foreign secretary beginning in August. Rao retired from the Indian Foreign Service and was appointed to succeed Meera Shankar as Ambassador to the United States.

\section{Early Obama Administration Engagement}

Just days into President Obama's term, Secretary of State Hillary Clinton and Indian External Affairs Minister S.M. Krishna agreed to "further strengthen the excellent bilateral relationship" between the United States and India. Soon after, President Obama issued a statement asserting that, "Our rapidly growing and deepening friendship with India offers benefits to all the world's citizens" and that the people of India "should know they have no better friend and partner than the people of the United States." As part of her confirmation hearing to become Secretary of State, Clinton told Senators she would work to fulfill President Obama's commitment to "establish a true strategic partnership with India, increase our military cooperation, trade, and support democracies around the world."

Despite such top-level assurances from the new U.S. Administration, during 2009 and into 2010, many in India became concerned that Washington was not focusing on the bilateral relationship with the same vigor as did the Bush Administration, which was viewed in India as having pursued both broader and stronger ties in an unprecedented manner. Many concerns arose in New Delhi, among them that the Obama Administration was overly focused on U.S. relations with China in ways that would reduce India's influence and visibility; that it was intent on deepening relations with India's main rival, Pakistan, in ways that could be harmful to Indian security and perhaps lead to a more interventionist approach to the Kashmir problem; that a new U.S. emphasis on nonproliferation and arms control would lead to pressure on India join such multilateral initiatives as the Comprehensive Test Ban Treaty and the Fissile Material Cutoff Treaty; and that the Administration might pursue so-called protectionist economic policies that could adversely affect bilateral commerce in goods and services. ${ }^{13}$

While some of these concerns persist, robust, positive, high-level U.S. attention to relations with India has continued. Secretary Clinton was widely seen to have concluded a successful visit to India in July 2009, inking several agreements, and also making important symbolic points by

\footnotetext{
${ }^{11}$ Teresita Schaffer, "Changing of the Guard at the U.S. Embassy in New Delhi," South Asia Hand (online), June 21, 2011. Amb. Roemer's statement at http://newdelhi.usembassy.gov/pr042811.html.

${ }^{12}$ Indian Ministry of External Affairs, "Telephonic Conversation Between EAM and US Secretary of State," January 23, 2009; White House statement at http://whitehouse.gov/58_years_of_Indian_democracy; hearing transcript at http://www.foreignpolicy.com/files/KerryClintonQFRs.pdf.

${ }^{13}$ In a development illustrative of India's early trepidation, two days after taking office, President Obama announced the appointment of former Clinton Administration diplomat Richard Holbrooke to be Special Representative to Afghanistan and Pakistan. Prior to the announcement, there was speculation that the new U.S. President would appoint a special envoy to the region with a wider brief, perhaps to include India and even Kashmir. Upon persistent questioning, a State Department spokesman insisted that Holbrooke's mandate was "strictly" limited to dealing with "the Pakistan-Afghanistan situation." By some accounts, the Indian government vigorously (and successfully) lobbied the Administration to ensure that neither India nor Kashmir were included in Holbrooke's official brief (see http://state.gov/r/pa/prs/dpb/2009/jan/115448.htm; “India's Stealth Lobbying Against Holbrooke's Brief," Foreign Policy (online), January 23, 2009).
} 
staying at Mumbai's Taj Mahal hotel (site of a major Islamist terrorist attack in 2008) and having a high-profile meeting with women's groups. ${ }^{14}$

In November 2009, President Obama hosted his inaugural state visit when Indian Prime Minister Manmohan Singh dined at the White House. Despite the important symbolism, the resulting diplomacy was seen by many proponents of closer ties as disappointing (if not an outright failure) in its outcome, at least to the extent that no "breakthroughs" in the bilateral relationship were announced. Yet from other perspectives there were visible ideational gains: the relationship was shown to transcend the preferences of any single leader or government; the two leaders demonstrated that their countries' strategic goals were increasingly well aligned; and plans were made to continue taking advantage of complementarities while differences are well managed. Perhaps most significantly, the visit itself contributed to ameliorating concerns in India that the Obama Administration was insufficiently attuned to India's potential role as a U.S. partner.

Still, in the wake of Prime Minister Singh's U.S. travel, some observers continued voicing concerns at the Obama Administration's perceived "air of ambivalence" toward India, with one going so far as to accuse the U.S. Administration of "diplomatic negligence" in its allegedly insufficient attention to New Delhi's key concerns, and for policies that could "put India into its subcontinental box" by relegating it to a regional role through the Asia-wide elevation of China. ${ }^{15}$

\section{June 2010 Strategic Dialogue}

The United States and India formally reengaged the U.S.-India Strategic Dialogue initiated under President G.W. Bush when a large delegation of high-ranking Indian officials led by External Affairs Minister Krishna visited Washington, DC, in June 2010. As leader of the U.S. delegation, Secretary Clinton lauded India as "an indispensable partner and a trusted friend." At a State Department reception, President Obama declared his firm belief that "the relationship between the United States and India will be a defining partnership in the $21^{\text {st }}$ century." 16

In anticipation of the Dialogue, Undersecretary of State for Political Affairs William Burns had given a policy speech on "India's rise and the future of the U.S.-India relationship" in which he asserted, "The simple truth that India's strength and progress on the world stage is deeply in the strategic interest of the United States." Burns acknowledged that progress in the partnership is not automatic and would require sustained efforts on both sides, and also that some Indians worry the United States sees India through the prism of ties with Pakistan and/or was overly focused on China. He sought to ameliorate these concerns by assuring his audience that the United States does not view relations in Asia as a zero-sum game and that its relations with Pakistan did not come at the expense of India. ${ }^{17}$ Two days later, the Strategic Dialogue produced a joint statement in which the two countries pledged to "deepen people-to-people, business-to-business, and

\footnotetext{
${ }^{14}$ In the resulting U.S.-India Joint Statement, Clinton and Krishna committed their respective countries to enhancing a strategic partnership that "seeks to advance solutions to the defining challenges of our time" and to concentrate work in 11 major issue-areas (see the July 20, 2009, text at http://meaindia.nic.in/mystart.php?id=530515048).

${ }^{15}$ Daniel Twining, "Diplomatic Negligence" (op-ed), Weekly Standard, May 10, 2010.

${ }^{16}$ See Secretary Clinton's and Minister Krishna's June 3, 2010, remarks to the media at http://www.state.gov/secretary/ rm/2010/06/142642.htm. President Obama's June 3, 2010, remarks at http://www.whitehouse.gov/the-press-office/ remarks-president-us-india-strategic-dialogue-reception.

${ }^{17}$ See the June 1, 2010, speech transcript at http://www.state.gov/p/us/rm/2010/136718.htm.
} 
government-to-government linkages ... for the mutual benefit of both countries and for the promotion of global peace, stability, and prosperity." 18

\section{President Obama's November 2010 Visit to India}

As the U.S. President planned his November 2010 visit to India, an array of prickly bilateral issues confronted him, including differences over the proper regional roles to be played by China and Pakistan; the status of conflict in Afghanistan; international efforts to address Iran's controversial nuclear program; restrictions on high-technology exports to India, outsourcing, and sticking points on the conclusion of arrangements for both civil nuclear and defense cooperation, among others. Moreover, while Indian officials will present a long list of demands to their American interlocutors, they come under fire for paying insufficient attention to American interests and concerns, and for not recognizing the sometimes serious costs of appearing insensitive to same.

Upon arriving in the Indian financial hub of Mumbai on November 7, 2010, President Obama laid a white rose at a memorial to the victims of the November 2008 terrorist attack and spoke at the Taj Mahal Palace hotel, a main target of that attack. While in that city, the President announced $\$ 10$ billion in new trade deals, among them a \$7.7 billion contract for Boeing to supply 30737 commercial aircraft to India's SpiceJet airline. The new deals were projected to create some 50,000 U.S. jobs. ${ }^{19}$ Many Indian observers were irked by the President's failure to mention Pakistan in his initial remarks, fueling for some a persistent Indian belief that the United States remains too devoted to its alliance with Islamabad. When asked about this in a meeting with a group of Mumbai college students, President Obama sought to impress upon the audience a belief that no country has a bigger stake in Pakistan's success than does India, commenting, "I think that if Pakistan is unstable, that's bad for India. If Pakistan is stable and prosperous, that's good."20

In New Delhi, President Obama's historic speech to a joint session of the Indian Parliament characterized the U.S.-India partnership as serving three broad purposes: (1) promoting prosperity on both countries, especially through greater trade and two-way investment, and food security and health-related initiatives; (2) enhancing shared security by working together to prevent terrorist attacks, and; (3) strengthening democratic governance and human rights. In the context of this last issue-area, President Obama chided India for often "shying away" from taking clear public stands in the face of gross human rights violations and the suppression of democratic movements, as was recently seen to be the case in Burma. ${ }^{21}$

\footnotetext{
${ }^{18}$ The Statement further outlined extensive bilateral initiatives in each of ten key areas: (1) advancing global security and countering terrorism; (2) disarmament and nonproliferation; (3) trade and economic relations; (4) high technology; (5) energy security, clean energy, and climate change; (6) agriculture; (7) education; (8) health; (9) science and technology; and (10) development. Secretary Clinton confirmed President Obama's intention to visit India in November 2010 (see the June 3, 2010, document at http://www.state.gov/r/pa/prs/ps/2010/06/142645.htm).

${ }^{19}$ The Administration subsequently touted myriad U.S. export initiatives that were generating jobs across every U.S. region and major commercial sector (see "The National Export Initiative" in "The U.S.-India Partnership: The Fact Sheets," White House release, November 8, 2010).

20 "Remarks by the President and First Lady in Town Hall With Students in Mumbai, India," White House release, November 7, 2010.

21 "Remarks by the President to the Joint Session of the Indian Parliament, New Delhi, India," White House release, November 8, 2010.
} 
While appearing a joint news conference, Prime Minister Singh called the American President "a sincere and valued friend" of India, and he welcomed an acceleration of the deepening of bilateral ties with an aim of working "as equal partners" in the relationship. For his part, President Obama reiterated his view that the U.S.-India relationship will be one of the defining partnerships of the $21^{\text {st }}$ century, and he reviewed the litany of varied bilateral initiatives both underway and planned. Both leaders expressed satisfaction with adjustments in U.S. export control regulations that are expected to facilitate greater joint cooperation in high-technology fields. ${ }^{22}$

\section{A Permanent U.N. Security Council Seat for India?}

During his address to Indian parliamentarians, President Obama received thunderous applause for his endorsement of a permanent Indian seat on the U.N. Security Council as part of elevating that country to "its rightful place in the world." 23 This was the most explicit such endorsement to date; previously, the U.S. government had endorsed only Japan as a new permanent member of that body. There is evidence of U.S. congressional support for a permanent Indian role on the Council. ${ }^{24}$ Although this unprecedented expression of support was widely hailed as a positive shift in U.S. policy, some Indian observers noted that the President's statement was not nearly as explicit an endorsement as was received by Japan and that, in the absence of a timeline for Security Council reform, it could be taken as little more than a "vague promise." 25 In neighboring Pakistan, the endorsement met with expected resistance; Islamabad claimed India is undeserving of such status given New Delhi's "conduct in relations with its neighbors and its continued flagrant violations of Security Council resolutions on Jammu and Kashmir."

\section{Reactions to the President's Visit}

President Obama's India trip was widely considered successful as a diplomatic exercise, although reviews of the substantive outcome were somewhat mixed. As External Affairs Minister Krishna later reported to his Parliament: "The visit was successful in strengthening mutual understanding on regional and global issues, accelerating the momentum of bilateral cooperation, and creating a long-term framework to elevate the India-U.S. strategic partnership to a new level." ${ }^{27}$ Assistant Secretary of State Robert Blake later said the trip "will be remembered as a watershed, when the U.S. and India embarked at a new level on concrete initiatives to build a global partnership." 28 The President's visit was itself seen by many in India and abroad as reflective of the country's

\footnotetext{
22 "Remarks by President Obama and Prime Minister Singh in Joint Press Conference in New Delhi, India," White House release, November 8, 2010.

${ }^{23}$ Specifically, the President said, "[I]n the years ahead, I look forward to a reformed United Nations Security Council that includes India as a permanent member" (see the November 8, 2010, speech transcript at http://www.whitehouse.gov/the-press-office/2010/11/08/remarks-president-joint-session-indian-parliament-new-delhiindia).

24 “Chairman Kerry Supports India Becoming a Permanent Member of the UN Security Council," SFRC press release, November 8, 2010. In the $111^{\text {th }}$ Congress H.Res. 1729 and H.Res. 1739 both expressed support for India's becoming a permanent member of the UN Security Council, although neither bill emerged from committee.

25 “Off-Mark on India's UNSC Dream" (editorial), Hindu (Chennai), November 12, 2010.

${ }^{26}$ See the Pakistani Foreign Ministry's November 8, 2010, release at http://www.mofa.gov.pk/Press_Releases/2010/ Nov/PR_279.htm.

${ }^{27}$ Ministry of External Affairs release, November 19, 2010.

28 "The Current State of U.S.-India Cooperation and Prospects for the Future (As Prepared)" (speech transcript), Department of State release, May 13, 2011.
} 
rising visibility on the global stage. Even in the absence of major new initiatives, there was a sense among some observers that the visit had exceeded expectations, with the U.S. President's "calm demeanor and soaring rhetoric" winning over a previously skeptical Indian audience. ${ }^{29}$

Other commentators, however, saw President Obama turning a blind eye toward or underestimating the seriousness of India's ongoing struggles with poverty, government bureaucracy, and health and education issues while remaining overly focused on the country's high-technology innovation successes. In these accounts, the New Delhi government's failure to push forward with economic reforms has made foreign investors wary, a problem only exacerbated by recent corruption scandals. ${ }^{30}$ There also continued to be contentions from some quarters that India's polity is skeptical about being subsumed into a U.S. "imperialist agenda," with fears that Indian commercial markets will be opened in ways that do not benefit the country's people and that India will be drawn into a military alliance with the United States. ${ }^{31}$

\section{July 2011 Strategic Dialogue}

Another Strategic Dialogue was held in New Delhi in July 2011. Given the persistence of doubts about the robustness of the U.S.-India relationship, there were hopes that Secretary Clinton's attendance could reinvigorate a relationship that many analysts still see as incomplete and in need of more specific focus. Clinton traveled with a group of nine other senior U.S. officials, including the Director of National Intelligence. Yet even before the final Joint Statement was issued, commentators were lowering expectations with the assumption that neither government's circumstances was ripe for new large-scale initiatives. ${ }^{32}$

Upon her arrival, Secretary Clinton highlighted three issue areas: (1) trade and investment ("This is a good news story, but ... Each of our countries can do more to reduce barriers, open our markets, and find new opportunities for economic partnership"); (2) security cooperation (especially on counterterrorism and maritime security); and (3) the civil nuclear agreement ("[T]o reap the benefits of that investment and to see returns on the political capital that has been spent on both sides, we need to resolve remaining issues....")..$^{33}$ The resulting Joint Statement highlighted a bilateral commitment to "broaden and deepen the U.S.-India global strategic partnership" in the cause of global stability and prosperity, and to enhance the partnership in numerous issue-areas. Among the notable clauses of the Statement were:

- a reaffirmation of the two countries' "commitment for consultation, coordination, and cooperation on Afghanistan," to include a reconciliation process there that is "Afghan-led, Afghan-owned, and inclusive";

- a call for Pakistan "to move expeditiously in prosecuting those involved in the November 2008 Mumbai terrorist attack”;

\footnotetext{
29 "Indian Media Sees [sic] Shift in Power in Obama Visit," Agence France Presse, November 7, 2010; quote from Mohan Guruswamy, "Obama Woos, Wows, and Wins India," Atlantic Council (online), November 24, 2010.

30 “'Obama Overrated India's Progress, Analysts Say,” Los Angeles Times, January 28, 2011; Sadanand Dhume, "Nothing Inevitable About India's Rise" (op-ed), Wall Street Journal, February 10, 2011.

${ }^{31}$ See, for example, Venkitesh Ramakrishnan, "Empty Euphoria," Frontline (Chennai), December 1, 2010.

32 “Can Clinton Jumpstart India-U.S. Relations?,” Wall Street Journal, July 19, 2011; Teresita Schaffer, "U.S.-India Strategic Dialogue: All-Star Cast, Playing Small Ball," Brookings Institution, July 19, 2011.

33 "Remarks at the Opening Session of the U.S.-India Strategic Dialogue," State Department transcript, July 19, 2011.
} 
- a continued commitment to "full implementation of the U.S.-India civil nuclear energy cooperation agreement"; and

- $\quad$ plans to resume technical-level negotiations on a bilateral investment treaty. ${ }^{34}$

In a major policy speech in the southern Indian city of Chennai (formerly Madras) the next day, Secretary Clinton laid out the Administration's vision for future relations, emphasizing India's growing leadership role in the world, especially in the Asia-Pacific and in South and Central Asia. On the former, and in what could be seen as a thinly veiled expression of concern about China's rise, she sought India's close cooperation in seeing formation of a regional architecture that adopts "international norms on security, trade, rule of law, human rights, and accountable governance." In this respect she welcomed New Delhi's "Look East" policy of closer engagement with the ASEAN countries. She also took the opportunity to issue an unusually open criticism of India's Burma policy, contending that, "As India takes on a larger role throughout the AsiaPacific, it does have increasing responsibilities, including the duty to speak out against violations of universal human rights." ${ }^{35}$ This last reflects a pervasive view in Washington that New Delhi is too hesitant to exercise India's growing power and influence.

On South and Central Asia, Secretary Clinton focused on three key issues. First, a reiteration of a strong and lasting U.S. commitment to Afghanistan well beyond the planned 2014 withdrawal of American combat troops, and a reiteration of "unambiguous redlines" for reconciliation with Afghan insurgents (their renunciation of violence, divorce from Al Qaeda, and acceptance of the laws and constitution of Afghanistan). She acknowledged New Delhi's "rightly expressed concerns about outside interference in the reconciliation process" and vowed to consult closely with India on this shared concern. Second, and related, Clinton stated that lasting peace and security in the region will "require a stable, democratic, prosperous Pakistan free from violent extremism," and assured listeners that the United States continues to press the Pakistani government to seek those ends. Finally, the new "Silk Road" initiative was raised: "an international web and network of economic and transit connections" that would facilitate regional commerce and prosperity. According to senior U.S. officials speaking later, this regional economic integration would be "anchored in the Indian economy." 36

As with President Obama's earlier travel to India, the Administration's second Strategic Dialogue session and Secretary Clinton's public appearances in New Delhi and Chennai were widely hailed as successful in moving the bilateral relationship forward. Yet, in another indication that current U.S.-India relations have no obvious, specific focus, the read-outs from two major wire services highlighted very different issue-areas. ${ }^{37}$

\section{India's Foreign Policy and Foreign Relations}

The end of Cold War political constraints and the rapid growth of India's economy has allowed New Delhi to more energetically engage global diplomacy. Expanded engagement is evident

\footnotetext{
34 “U.S.-India Strategic Dialogue Joint Statement,” U.S. Embassy press release, July 19, 2011.

35 "Remarks on India and the United States: A Vision for the $21^{\text {st }}$ Century," State Department transcript, July $20,2011$.

${ }^{36}$ Ibid.; author conference call with senior U.S. officials, July 21, 2011.

37 "US Vows Counterterrorism Support for India," Associated Press, July 19, 2011; "Clinton Pushes India on Nuclear Law, Market Access," Reuters, July 19, 2011.
} 
through the huge increase in the number of bilateral defense arrangements the Indian government has made in the past decade, more than tripling from 7 in 2000 to at least 26 today. During the latter half of 2010, every major world leader paid a visit to India, including those from all five permanent U.N. Security Council members. Much of the international attention on India is due to the country's vast market potential — the retail sector alone is worth an estimated $\$ 450$ billion.

Some observers argue that the New Delhi government acts too timidly on the global stage, and that the country's regional and domestic difficulties continue to hinder its ability to exert influence in geopolitics. As a rising power, India has appeared unwilling to take the kinds of policy stances expected of major global players, in particular those who sit on the U.N. Security Council, as India has been in 2011. ${ }^{38}$ From vague positions on Middle East uprisings to the appearance of fence-sitting on issues such as U.S.-led efforts to isolate Iran and Burma, New Delhi's leaders may be finding it increasingly difficult to avoid taking on the responsibilities many in Washington and elsewhere are looking for. One example is New Delhi's largely handsoff response to uprisings in the Arab world, with External Affairs Minister Krishna saying India would not "jump into the fray" unless invited and would maintain a "very cautious" approach to the Libyan conflict. ${ }^{39}$ In March 2011, India officially opposed NATO's military action in Libya and notably abstained - along with Brazil, China, Russia, and Germany-from voting on U.N. Resolution 1973, which approved of such action. ${ }^{40}$ More recently, Secretary of State Clinton has sought greater Indian assistance in pressuring the faltering Syrian regime.

Human rights activists have joined foreign governments in prodding India to be more proactive on key foreign policy issues, even those in India's own neighborhood such as in Burma and Sri Lanka. One such observer has criticized New Delhi for issuing "bland propositions" that "can convey indifference to the plight of subjugated people." She challenges India's leaders to "stand with people or with dictators."

Many analysts view India's foreign policy establishment-its foreign service, think-tanks, public universities, and relevant media - as being too small and/or too poorly developed for India to achieve true great power status in the foreseeable future. By one substantive account, without a major modernizing and revamping of this establishment, "India's worldview will be parochial, reactive, and increasingly dominated by business rather than by strategic or political concerns. ${ }^{, 42}$ Thus, even as India's rising stature commands greater attention in many world capitals, the country's diplomatic influence remains limited - especially in comparison to that of China - and the central government continues to concentrate mainly on domestic development and poverty alleviation. Indeed, India's domestic and social indices continue to rank it as a developing country, or what one former senior Indian diplomat called a "premature power." Indian bureaucrats' prickly and sometimes distrustful attitude toward their American counterparts

\footnotetext{
${ }^{38}$ In October 2010, India was elected to a nonpermanent UNSC seat, its first appearance in that body in 20 years.

39 "India Finds Its Seat on the Fence Increasingly Uncomfortable," Washington Post, February 19, 2011; Krishna quoted in "India Will Not Offer Unsolicited Advice to Arab Nations: Krishna," Hindu (Chennai), February $28,2011$.

${ }^{40}$ One American commentator rued the abstention as being harmful to India's global moral and political standing, saying it would confirm the misgivings of those who doubt the country's willingness to make difficult choices (Sumit Ganguly, "A Pointless Abstention," Diplomat (Tokyo), March 23, 2011).

${ }^{41}$ Meenakshi Ganguly, "India, Arab Democracy, and Human Rights," Open Democracy (online), March 8, 2011.

42 Daniel Markey, “Developing India’s Foreign Policy 'Software,”’ Asia Policy, July 2009.

${ }^{43}$ Shyam Saran, “A Premature Power?” (op-ed), Outlook (Delhi), November 2, 2010.
} 
survives long after the Cold War's end, and is sometimes evident in New Delhi's vehement reactions to what many Americans would consider minor and essentially meaningless slights. ${ }^{44}$

\section{Major Streams of Thought in Indian Foreign Policy}

In the assessment of one former U.S. diplomat and longtime South Asia expert, there are two major schools of thought in India's current foreign policy approach: " $21^{\text {st }}$ century Nehruvian" and "great power advocates." 45 The former is notable for its essential continuation of Jawaharlal Nehru's emphasis on developing world unity and an attendant skepticism regarding U.S. power, which, from this view, may require taking action to balance against. ${ }^{46}$ The latter, energized by India's rapid economic growth and higher visibility on the world stage, concentrates on New Delhi's triangular relations with Washington and Beijing with an eye toward increasing India's relative power, mainly through economic growth and innovation. Yet both schools share several important basic characteristics, including a view of India as a more-or-less natural regional hegemon; limited attention to global governance issues; a commitment to maintaining India's "strategic autonomy"; and a preference for hedging strategies, be they balancing against a more aggressive China by welcoming a continued major U.S. presence in the region, or by working with China and Russia to preclude an excessively dominant American presence.

In an informal but extensive survey of Indian elite opinion about the United States, this same expert found broad areas of consensus and concluded that Washington has now supplanted Moscow as New Delhi's most important external partner. As is reflected in opinion surveys of the Indian public more broadly, views of the United States, its varied power capabilities, and its continued substantive presence as a player in Asia are widely welcomed by Indian decision makers. The United States is seen to possess a unique ability to turn innovation into wealth and military power, both coveted by aspiring global powers such as India. America's national will and soft power tend to be admired by Indians, and the leading U.S. role in international institutions may serve as a model for New Delhi. Moreover - 40 years after the Nixon Administration was seen to "tilt" toward Pakistan by sending the USS Enterprise carrier task force into the Bay of Bengal-American military capabilities and ability to project significant power into the Indian Ocean Region are no longer viewed as threatening to most in New Delhi, where there is a widely held view of the United States as the only viable hedge against the rise of a potentially adversarial or revisionist China. ${ }^{47}$

The above-noted schools of thought correspond closely to what two other senior observers identify as India's "traditional nationalist" and "pragmatist" strains of foreign policy visions. These analysts see policy makers tending to "split the difference" by mouthing traditional nationalist rhetoric while pursuing a largely pragmatic course. While nationalists are inherently opposed to any international alliance that would constrict India's autonomy and tend toward legal-moral rather than political arguments, pragmatists are accepting of a balance of power approach emphasizing a flexible pursuit of Indian national interests over ideological positioning.

\footnotetext{
${ }^{44}$ Sumit Ganguly, “Old Friends Yes, But Are We Real Buddies?” (op-ed), Times of India (Delhi), November 7, 2010.

${ }^{45}$ Teresita Schaffer, "New Delhi’s New Outlook” (review essay), Survival, December 2010.

${ }^{46}$ The Nehruvian approach is also associated with "strategic restraint," a tenet that arguably has failed India in its dealings with both China and Pakistan, but that continues to endure (Sunil Dasgupta and Stephen Cohen, "Is India Ending Its Strategic Restraint Doctrine?," Washington Quarterly, Spring 2011).

${ }^{47}$ Teresita Schaffer, "Continued Primacy, Diminished Will: Indian Assessments of U.S. Power," in Craig Cohen, ed., Capacity and Resolve: Foreign Assessments of U.S. Power (Center for Strategic and International Studies, June 2011).
} 
One result is that pragmatists are less averse to alliance-making and international treaties. Their rising influence thus opens greater possibilities for closer and more meaningful U.S.-India ties, perhaps especially in the area of nonproliferation (New Delhi's Iran policy has become a bellwether issue of contention between nationalists and pragmatists). ${ }^{48}$

\section{Rivalry and Conflict With Pakistan ${ }^{49}$}

Three full-scale wars — in 1947-1948, 1965, and 1971—and a constant state of military preparedness on both sides of their mutual border have marked more than six decades of bitter rivalry between India and its western neighbor, Pakistan. The acrimonious partition of British India into two successor states in 1947 and the unresolved issue of Kashmiri sovereignty have been major sources of tension. Both countries have built large defense establishments at significant cost to economic and social development, and the bilateral conflict has precluded the development of meaningful regional organizations.

A major factor in U.S. interest in South Asia is ongoing tension between India and Pakistan rooted largely in competing territorial claims and in "cross-border terrorism" in both Kashmir and major Indian cities. In the interests of regional stability, the United States strongly endorses a recently revived India-Pakistan peace initiative, and it remains concerned about the potential for India-Pakistan to cause open hostilities between these two nuclear-armed countries. Senior Indian officials continue to press the U.S. government to convince Islamabad to take stronger action against anti-India terrorist groups operating inside Pakistan.

The effects of this bilateral conflict are seen to negatively affect U.S.-led efforts to stabilize Afghanistan. Most observers assert that U.S. success in Afghanistan is to a significant degree dependent on improved India-Pakistan relations, the logic being that Pakistan will need to feel more secure vis-à-vis a perceived existential threat on its eastern front in order to shift its attention and military resources more toward the west. Some in Pakistan believe that, by feeding their country's insecurities, the increasingly warm U.S.-India relationship actually foments regional instability.

In 2010, Indian decision makers became discomfited by signs that the United States and its allies are preparing to leave Afghanistan in such a way that would provide a central role for Pakistan in mediating between Kabul and Taliban elements, perhaps even to include a role for the latter in Afghanistan's governance. Such an outcome would be anathema to Indian leaders, who wish to limit Islamabad's influence in a post-war Afghanistan. During his 2010 confirmation hearing, the U.S. military commander in Afghanistan (and current Director of Central Intelligence), Gen. David Petraeus, said India "without question" has a legitimate interests in Afghanistan.

Also in 2010, conflict over water resources emerged as another major exacerbating factor in the bilateral relationship. Some in Pakistan accuse India of violating international law, bilateral agreements, and ethical principles of peaceful coexistence through the allegedly illicit manipulation of water flows into Pakistan. Of particular concern for Indian and Western observers has been the fact that some of these complaints are emanating from the leaders of

\footnotetext{
${ }^{48}$ Deepa Ollapaly and Rajesh Rajagopalan, "The Pragmatic Challenge to Indian Foreign Policy," Washington Quarterly, Spring 2011.

${ }^{49}$ See also CRS Report R41307, Pakistan: Key Current Issues and Developments, and CRS Report R41832, PakistanU.S. Relations: A Summary, both by K. Alan Kronstadt.
} 
militant Pakistani Islamist groups such as Lashkar-e-Taiba. Pakistan's then-foreign minister said water was "emerging as a very serious source of [bilateral] tension," but a senior Indian official denied that India is in violation of the Indus Waters Treaty and called Pakistani rhetoric a "political gimmick" meant to distract from Islamabad's own poor water management. ${ }^{50}$

The Indian government suspended the bilateral peace process following the late 2008 terrorist attack on Mumbai that was traced to a Pakistan-based terrorist group. In early 2011, New Delhi chose to reengage dialogue with Islamabad despite the fact that many of the alleged planners of that attack have not been brought to justice. A panel of experts of security and terrorism brought together by India Today magazine in 2010 outlined ten strategies for India-Pakistan dialogue. Each of the top three involved actions to be taken by Pakistan: (1) firmer and more rapid action the perpetrators of the 11/08 Mumbai attack; (2) extradition of the fugitives most wanted in India; and (3) action against the "terrorist infrastructure" on Pakistani soil. The experts also called for establishment of a regular dialogue between the two countries' intelligence chiefs. ${ }^{51}$ These remain among New Delhi's key concerns.

The immense pressures now faced by Islamabad — ongoing and widespread Islamist militancy and extremism, the unprecedented embarrassments of bin Laden's discovery and an attack on a naval base in May, and deteriorating relations with the United States foremost among them-may have the effect of shifting the focus of Pakistan's military decision makers away from conflict with New Delhi. This may in turn open a window of opportunity for India to pursue improved relations with Pakistan. ${ }^{52}$

\section{The India-Pakistan Peace Process}

\section{Background}

A bilateral "Composite Dialogue" between New Delhi and Islamabad, initiated in the 1990s and officially resumed in 2004, has realized some modest but still meaningful successes, including a formal cease-fire along the entire shared frontier, and some unprecedented trade and people-topeople contacts across the Kashmiri Line of Control (LOC). As per New Delhi's and Islamabad's intents, the dialogue has been meant to bring about "peaceful settlement of all bilateral issues, including Jammu and Kashmir, to the satisfaction of both sides." ${ }^{, 53}$ Yet 2008 saw significant deterioration in India-Pakistan relations, especially following the large-scale November terrorist attack on Mumbai, India, that left some 165 civilians dead (22 of those killed were foreigners, including 6 Americans). More broadly, militarized territorial disputes over Kashmir, the Siachen Glacier, and the Sir Creek remain unresolved, and Pakistani officials regularly express unhappiness that more substantive progress, especially on the "core issue" of Kashmir, is not occurring. Officials in New Delhi continue to declare unacceptable the "terrorist-infrastructure" they say remains intact in Pakistani Kashmir.

\footnotetext{
50 “Pakistan Steps Up Water Dispute,” Financial Times (London), March 29, 2010; quotes in “India and Pakistan Feud Over Indus Waters," Wall Street Journal, March 31, 2010.

${ }^{51}$ Other strategies include (5) halting cross-border infiltrations in Kashmir; (6) settling water disputes; (7) expanding economic cooperation; (8) establishing a permanent ceasefire along the Kashmiri Line of Control; (9) implementing back channel Kashmir proposals; and (10) promoting greater people-to-people contacts ("Getting Tough on Peace," India Today (Delhi), March 1, 2010).

${ }^{52}$ See C. Raja Mohan, “Something's Changing” (op-ed), Indian Express (Mumbai), June 23, 2011.

${ }^{53}$ See the January 6, 2004, joint statement at http://www.indianembassy.org/press_release/2004/jan/07.htm.
} 
The Obama Administration continues to refrain from taking any direct role in the bilateral dispute, and Indian leaders see no need for third-party involvement, in any case. However, to the satisfaction of his Indian audience, while in New Delhi in late 2010, President Obama said, "We'll continue to insist to Pakistan's leaders that terrorist safe havens within their borders are unacceptable, and that terrorists behind the Mumbai attacks must be brought to justice."

\section{Developments in 2010}

Despite its formal suspension of the peace process, New Delhi did continue engaging in highlevel talks with Islamabad in 2010. Pakistani observers variously attributed this Indian willingness to an apparent failure of coercive diplomacy, to U.S. pressure, and to new talk of reconciliation with the Afghan Taliban, which could leave India in a disadvantageous position vis-à-vis Kabul. From the Indian perspective, New Delhi's leaders were compelled by the desire to offer Islamabad tangible benefits for cooperating, and by a perceived need for greater flexibility in the case of future terrorists attacks traced to Pakistan. Islamabad welcomed this Indian willingness to talk, seeing it as an opportunity to raise "all core issues" and urge India to resolve them quickly. New Delhi reiterated that the Composite Dialogue remained in suspension and that, while all subjects could be raised at impending meetings, India would focus solely on terrorism.

A series of high-level interactions ensued, but none produced any new agreements or major initiatives. Pakistani Foreign Secretary Salman Bashir visited New Delhi in February. Following that meeting, India's then-Foreign Secretary Rao said the time was not yet right for a resumption of the Composite Dialogue as requested by Islamabad. Subsequent major military exercises by both countries near their shared border (India in February, Pakistan in April) indicated that mutual distrust remained serious. In April, senior Indian leaders still ruled out any renewal of substantive talks until Pakistan took "credible steps" to bring Mumbai perpetrators to justice. Yet Prime Minister Singh did meet with his Pakistani counterpart on the sidelines of a regional summit in April 2010 in Thimpu, Bhutan, where the Indian leader expressed a willingness to discuss all issues of mutual interest, apparently with the conviction that even a dialogue that produces no immediate results is preferable to a diplomatic freeze. More high-level talks were held in Islamabad in June when Secretary Rao again met her Pakistani counterpart. The very fact of the meeting had many observers optimistic that the bilateral peace process was getting back on track. External Affairs Minister Krishna was in Islamabad a month later, but what he called "good and constructive" talks produced only an agreement to keep talking. Islamabad called India's "selective" approach to outstanding issues (an oblique reference to Kashmir) a major impediment. Despite their strong suspicion of official Pakistani involvement in the 2008 Mumbai attack, Indian leaders saw no good option other than continuing the dialogue. ${ }^{55}$

\section{Developments in 2011}

Given a lack of progress with its so-called "coercive diplomacy," the national coalition-leading Congress Party announced that it would officially reengage dialogue with Pakistan. The decision

\footnotetext{
54 "Remarks by the President to the Joint Session of the Indian Parliament, New Delhi, India," White House release, November 8, 2010.

55 “No Option But to Keep Talking to Pak: Rao,” Times of India (Delhi), August 9, 2010.
} 
met with some political resistance from the opposition. ${ }^{56}$ A June meeting of foreign secretaries in Islamabad appeared unexpectedly positive to many, with the two officials agreeing to expand confidence-building measures related to both nuclear and conventional weapons, as well as to increase trade and travel across the Kashmiri LOC. ${ }^{57}$ In July, new Pakistani Foreign Minister Hina Rabbani Khar was in New Delhi for talks with External Affairs Minister Krishna, who reaffirmed India's intention to reduce the bilateral trust deficit and conveyed New Delhi's desire for "a stable, prosperous Pakistan acting as a bulwark against terrorism, and at peace with itself and with its neighbors." Khar had raised some hackles in New Delhi-and an explicit expression of "displeasure" from Krishna - by meeting with Kashmiri separatists before seeing Indian government officials. ${ }^{58}$ Yet the resulting Joint Statement further loosened trade and travel restrictions across the LOC, and was widely taken as a successful representation of a peace process back on track after a more than two-year hiatus. ${ }^{59}$

\section{Mumbai Terrorist Attacks and the LeT ${ }^{60}$}

The perpetrators of a horrific terrorist attack on India's business and entertainment capital that resulted in 165 innocent deaths were identified as members of the Pakistan-based Lashkar-eTaiba (LeT), a U.S.-designated terrorist group that has received significant past support from Pakistani security agencies (the Jamaat-ud-Dawa or JuD, ostensibly a charitable organization, is widely considered to be a continuation of the LeT under a new name). The Indian government demands that Pakistan take conclusive action to shut down the LeT and bring its terrorist leadership to justice. At least one ranking Indian official has openly accused Pakistan's powerful main intelligence agency of overseeing the planning and execution of the attack. ${ }^{61}$ After being granted access to David Headley, an American national of Pakistani descent who pled guilty to participating in the planning of the attack, Indian officials claimed to have established an official Pakistani role, a claim Islamabad strongly rejected as "baseless." "2 Yet reports continue to finger Pakistan's main intelligence service as being culpable.

Of particular relevance for India is LeT founder Hafiz Saeed, whom India believes is demonstrably culpable, but whom Pakistani officials say they do not possess sufficient evidence to formally charge. In September 2009, Pakistani police placed Saeed under house arrest. Only weeks later, a court dismissed the two cases brought against him (unrelated to the Mumbai attack), but he remained confined to his home. The Islamabad government insisted that it was powerless to take further action against Saeed in the absence of more convincing evidence of wrongdoing. New Delhi countered that Pakistan was "shielding" the masterminds of the attack. In

\footnotetext{
${ }^{56}$ The main opposition Bharatiya Janata Party expressed "shock," saying Pakistan had done nothing to earn such recognition ("No Reason to Renew Talks With Pakistan: BJP," Hindu (Chennai), April 15, 2011).

${ }^{57}$ See the June 24, 2011, Joint Statement at http://www.mofa.gov.pk/Press_Releases/2011/June/Pr_218.htm.

${ }^{58}$ External Affairs Ministry transcript, August 3, 2011.

${ }^{59}$ See the July 27, 2011, text at http://meaindia.nic.in/mystart.php?id=530517878.

${ }^{60}$ See also CRS Report R40087, Terrorist Attacks in Mumbai, India, and Implications for U.S. Interests, by K. Alan Kronstadt.

61 “India: Pakistan Spy Agency Executed Mumbai Attacks,” Associated Press, July 14, 2010. In 2010, Interpol issued warrants for five Pakistani nationals in relation to the attack, among them two army officers.

62 "Indian Probe of Mumbai Suspect Headley Exposed Official Role, Menon Says," Bloomberg, July 20, 2010. In June 2011, a Chicago jury found Tahawwur Rana, a Canadian citizen, guilty of providing material support for LeT and for conspiring in a terrorist plot against a Danish newspaper, but acquitted him on charges of charges related to the 2008 Mumbai attack.
} 
May 2010, Pakistan's Supreme Court dismissed a government appeal and upheld a lower court's decision to release Saeed, saying the case presented against him was insufficient. A senior Indian official expressed disappointment with the ruling. Many analysts believe Saeed maintains substantive control of the organization's daily operations even as he remains under house arrest.

In late 2009, Pakistani authorities had brought formal charges against seven men accused of planning the Mumbai raid, among them Zaki ur-Rehman Lakhvi, a senior LeT figure said to have been the operational commander. New Delhi insists that the suspects be extradited to India. ${ }^{63}$ Yet the Islamabad government refuses and has to date pressed no further than preliminary hearings, and the start-and-stop nature of the proceedings has only engendered Indian and international skepticism about Pakistan's determination. While in India in July 2011, the Pakistani foreign minister asked Indian officials to have "patience, trust, and confidence in the proceedings," saying "Pakistan was not trying to abdicate responsibility." 64

Osama bin Laden's May 2011 killing by U.S. commandos in the Pakistani city of Abbottabad elicited more insistent Indian demands that Islamabad hand over the Mumbai suspects, but to no avail. One senior observer, reflecting a widely-held view, contends that the Pakistani military "will do everything to preserve Lashkar as long as it believes there is a threat from India." Analysts warn that another major terrorist attack in India that is traced to Pakistan would likely lead to an international crisis. One has offered numerous U.S. policy options for preventing such an attack or managing any crisis that results. ${ }^{65}$

July 2011 terrorist bombings in Mumbai-most likely the work of indigenous Islamist militants - were evidence for many that the city remains highly vulnerable to attack. Well after the 2008 attacks, measures had been taking to improve the city's security, but major initiatives such as establishment of a dedicated federal ministry were not taken up, and nearly all of the political and police officials involved had avoided termination or even reprimand.

\section{The Kashmir Dispute ${ }^{66}$}

Many U.S. officials, as well as the Pakistani government, aver that regional peace is inextricably linked to a solution of the Kashmir dispute. New Delhi views separatism in its Jammu and Kashmir state to be an internal issue or, at most, a bilateral one with Pakistan. It rejects any thirdparty or multilateral engagement. While levels of violence in Kashmir have declined significantly from their 1990s peak, the situation remains fragile, and Islamabad insists that what it calls New Delhi's "administrative and half-hearted political measures" will not resolve what is in essence a Kashmiri "struggle for the right to self-determination." 67

\footnotetext{
${ }^{63}$ Pakistan's Prime Minister has stated that, because Pakistan has no extradition treaty with India, Pakistani suspects will not be handed over, adding that his country's laws do not allow for prosecutions of terrorist acts committed outside of Pakistan and would need to be amended in order to try Mumbai attack suspects.

${ }^{64}$ Ministry of External Affairs transcript, August 3, 2011.

${ }^{65}$ Ahmed Rashid, "The Afghanistan Impasse” (review), New York Review of Books, September 10, 2009; Daniel Markey, "Terrorism and Indo-Pakistani Escalation," Council on Foreign Relations Contingency Planning Memorandum No. 6, January 2010.

${ }^{66}$ For broader discussion on Kashmir, see the "Separatism in the Jammu and Kashmir State" section below.

${ }^{67}$ See the July 2, 2009, Pakistan Foreign Ministry press briefing at http://www.mofa.gov.pk/Pages/2009/July/ Spokes_02_07_09.htm.
} 
Under the Obama Administration, the U.S. government has continued its long-standing policy of keeping distance from the Kashmir dispute and refraining from any mediation role therein. As expressed by President Obama in speaking to a joint session of the Indian Parliament, "We will continue to welcome dialogue between India and Pakistan, even as we recognize that disputes between your two countries can only be resolved by the people of your two countries." 68 The now deceased U.S. Special Representative for Afghanistan and Pakistan, Richard Holbrooke, who at times used the term "K-word" in discussing Kashmir, said, "We are not going to negotiate or mediate on that issue and I'm going to try to keep my record and not even mention it by name." 69

Officially, India lays claim to the entire former princely state, but in practice New Delhi is generally accepting of the status quo wherein it controls two-thirds, including the prized, Muslimmajority Kashmir Valley, site of the state's summer capital and largest city, Srinagar (pop. 1.3 million). Indian policy will not accept any territorial or border shifts, but Prime Minister Singh has for many years sought to "make the border irrelevant" and open the LOC to greater trade and people-to-people contacts. A rare major opinion survey of 3,700 Kashmiris on both sides of the LOC in 2010 found that less than half supported separatist goals. Only in the Muslim-majority valley did a large majority (up to $95 \%$ ) express support for full Kashmiri independence. ${ }^{70}$

Indian officials consistently aver that, despite significant decreases in rates of separatist violence, the Pakistani threat to Indian Kashmir remains undiminished, with Pakistan accused of providing occasional support for militant infiltration across the LOC, as well as of maintaining — or at the very least tolerating - militant bases in Pakistani Kashmir. In 2010, India's defense minister claimed there were "conscious, calculated attempts" underway to push more militants into the Valley, and the army chief later reiterated his claim that Pakistan was not taking action to dismantle the "terror infrastructure" on its side of the LOC. According the Indian Home Ministry's most recent annual report, "[T]here are reports to indicate that the infrastructure for training to terrorist elements across-the border continues to remain intact and efforts to infiltrate militants into the State continue unabated." ${ }^{, 1}$

During the summer of 2010, Indian Kashmir experienced its worst separatist-related violence in years. The spasm began in June, when a 17-year-old protester was killed by a tear gas canister fired by police. By mid-September, more than 100 other mostly young street protesters died in clashes with security forces, a curfew was imposed in the Valley, dozens of separatist political leaders were arrested, and thousands of Indian police and paramilitary troops were deployed to quell the protests. Pakistan's Foreign Ministry issued a formal condemnation of "the blatant use of force by Indian security forces," called the ongoing violence "unacceptable," and asked New Delhi to "exercise restraint." The Pakistani Parliament subsequently passed resolutions on the issue; New Delhi angrily rejected the attempted interference in "what is purely an internal affair of India." Islamabad was not deterred, however, and further sharp diplomatic exchanges ensued. ${ }^{72}$ A feared repeat of such turmoil did not materialize in the summer of 2011 (see also the "Separatism in the Jammu and Kashmir State" section below).

\footnotetext{
68 "Remarks by the President to the Joint Session of the Indian Parliament, New Delhi, India," White House release, November 8, 2010.

${ }^{69}$ See the State Department's February 3, 2010, release at http://fpc.state.gov/136466.htm.

70 ““First' Kashmir Survey Produces 'Startling' Results,” BBC News, May 27, 2010.

${ }^{71}$ Ministry of Home Affairs Annual Report 2010-11 Report at http://mha.nic.in/pdfs/AR(E)1011.pdf.

${ }^{72}$ Pakistan Foreign Ministry's September 17, 2010, statement at http://www.mofa.gov.pk/Press_Releases/2010/Sept/ PR_224.htm; "India and Pakistan Spar Over Kashmir," BBC News, September 29, 2010.
} 


\section{India and the Afghan Insurgency ${ }^{73}$}

\section{Partnership and Reconstruction Assistance}

Indian leaders envisage a peaceful Afghanistan that can serve as a hub for regional trade and energy flows. India takes an active role in assisting reconstruction efforts in Afghanistan, having committed a total of some $\$ 2$ billion to this cause since 2001 (the most recent pledge of $\$ 500$ million was made in May), as well as contributing thousands of workers and opening four consulates there. It is the leading regional contributor to Afghan reconstruction. New Delhi characterizes its relations with Kabul as unique in that Indian humanitarian assistance and infrastructure development projects are geographically extensive while also entirely Afghan-led in terms of prioritization. India's wide-reaching assistance program in the country is aimed at boosting all sectors of development in all areas of Afghanistan.

In May 2011, Prime Minister Singh met with Afghan President Hamid Karzai in Kabul, where the two leaders announced a new India-Afghanistan "Strategic Partnership" elevating bilateral ties to a higher level with regular summit meetings, expanded trade and commercial links, and institutionalized dialogues on an array of bilateral issues. New Delhi vows to assist in Afghanistan's emergence "as a land bridge and trade, transportation and energy hub connecting Central and South Asia by enabling free and more unfettered transport and transit linkages." Singh pledged another $\$ 500$ million in bilateral development aid over the next six years. ${ }^{74}$

Among Indian assistance to Afghanistan are funding for a new \$111 million power station, a \$77 million dam project, construction of Kabul's new \$67 million Parliament building, and construction of Afghanistan's leading children's hospital. Indian engineers also have completed a 160-mile-long, \$84 million road project linking Afghanistan's southwestern Nimroz province with Iran's Chabahar port on the Arabian Sea in hopes of providing landlocked Afghanistan with an alternative supply route and reducing the country's dependence on access through Pakistan. India provides daily school lunches to two million Afghan children. In December 2010, India signed agreements to participate in the multi-billion-dollar Turkmenistan-Afghanistan-PakistanIndia (TAPI) gas pipeline project, which leaders hope to see completed in 2015 (India's former petroleum minister characterized the project as a new "Silk Route" linking Central and South Asia). Thousands of Indian personnel are working on various relief and reconstruction projects inside Afghanistan. These workers are guarded by hundreds of Indian police forces which have sustained casualties in attacks by insurgents. In the private sector, Indian firms are vying for exploration rights in Bamiyan, Afghanistan, where the Hajigak mines contain some 1.8 billion tons of high-quality iron ore.

\section{Afghan Reconciliation, Security Concerns, and the U.S. Drawdown}

New Delhi declares itself "committed to the unity, integrity, and independence of Afghanistan underpinned by democracy and cohesive pluralism and free from external interference." It supports efforts toward peace and reintegration with Taliban insurgents, but emphasizes that, to be successful and enduring, these should be wholly "Afghan-led and Afghan-owned," the clear

\footnotetext{
${ }^{73}$ See also CRS Report RL30588, Afghanistan: Post-Taliban Governance, Security, and U.S. Policy, by Kenneth Katzman.

${ }^{74}$ See the May 12, 2011, Joint Declaration at http://meaindia.nic.in/mystart.php?id=530517624.
} 
implication being that Islamabad's substantive involvement is not desired. In May 2011, Prime Minister Singh reiterated his government's wish that an Afghan-led reconciliation process takes place "without outside interference or coercion." 75 After a long period of uneasiness with the idea of President Karzai negotiating directly with Afghan insurgents, New Delhi's leadership -in line with a similar policy shift by the United States - now fully supports a reconciliation process that might include discussions with Taliban elements. Yet hardline Indian analysts foresee "catastrophic" implications for India's security if Pakistan takes a major role in the Afghan endgame, and New Delhi continues to worry about Washington's "toxic dependence" on the Pakistani army in pursuing a military victory in Afghanistan. ${ }^{76}$

New Delhi's keen security interests in Afghanistan are longstanding, and Indian investment in that country is motivated by a desire to bypass Pakistan when engaging West and Central Asia, constrain the spread of Islamist militancy on its western flank, and also dampen the influence of both Islamist and Hindutva extremism domestically. Yet Indian efforts to project influence into Afghanistan are significantly hindered by geography and ethnicity (where Pakistan enjoys clear advantages), Islamabad's demonstrated willingness to undertake provocative anti-India policies in Afghanistan, and, perhaps most importantly, ambivalence among Indian policy makers and ordinary citizens alike about the cost-benefit calculation of continuing what may be risky investments in an unstable country. Given the June 2011 announcement of an impending U.S. drawdown from Afghanistan, New Delhi faces a choice of maintaining/increasing its efforts in Afghanistan, risking potentially dangerous reactions from Islamabad, or scaling back its efforts in the hope of easing Pakistan's insecurities. The latter option may facilitate greater stability, but at considerable cost to India's aspirations for regional dominance and global power status. ${ }^{77}$

By some accounts, India and Pakistan are fighting a "shadow war" inside Afghanistan with spies and proxies, although it is exclusively high-visibility Indian targets that have come under attack there. A July 2008 suicide bombing at India's Kabul Embassy was traced to militants with ties to the Pakistani military, and was taken as a stark message to Indian leaders that Taliban militants and their allies want New Delhi to withdraw from Afghanistan. ${ }^{78}$ Prime Minster Singh instead responded by pledging $\$ 450$ million in new Indian aid for Afghan reconstruction.

Islamabad accuses New Delhi of using an exaggerated number of Indian consulates in Afghanistan as bases for malevolent interference in Pakistan's Baluchistan province, specifically by materially supporting Baloch separatist militants. The Pakistani government also accuses India of interfering in Pakistan's western tribal regions along the Afghanistan border. When asked about such claims in late 2009, Secretary of State Clinton said the U.S. government had seen no supporting evidence. Yet senior Pakistani officials remained insistent. ${ }^{79}$

In the view of many analysts, Pakistan's "paranoia" with regard to the perceived threat from India leads Pakistani leaders to engage a zero-sum regional competition with New Delhi. In this way,

${ }^{75}$ See the July 20, 2010, statements of External Affairs Minister Krishna at http://meaindia.nic.in/mystart.php?id= 530116150; May 13, 2011, statements of Prime Minister Singh at http://meaindia.nic.in/mystart.php?id=530117626.

${ }^{76}$ See "India's Role in Afghanistan," International Institute for Strategic Studies Strategic Comment, June 2011; Harsh Pant, "India Finds Its Second Wind in Afghanistan" (op-ed), Japan Times (Tokyo), June 6, 2011; Siddharth

Varadarajan, "A Fork in the Road for the U.S. in South Asia” (op-ed), Hindu (Chennai), May 2, 2011.

${ }^{77}$ See C. Christine Fair, "Under the Shrinking U.S. Security Umbrella: India's End Game in Afghanistan?," Washington Quarterly, Spring 2011.

78 ”Afghan Bombing Sends Stark Message to India,” New York Times, July 9, 2008.

${ }^{79}$ State Department transcript, October 26, 2009. 
Pakistan's primary goal with regard to Afghanistan is to prevent any dominant Indian influence there ${ }^{80}$ Signs of increasing cooperation between the Kabul and Islamabad governments can cause trepidation in other regional capitals, especially including New Delhi, for above-noted reasons.

Some observers viewed a senior U.S. military commander's 2009 assessment that "increasing India's influence in Afghanistan is likely to exacerbate regional tensions" as a sign that U.S. officials might press India to keep a low or lower profile there, yet the U.S. government has continued to welcome and laud India's role in Afghanistan while at the same time rhetorically recognizing Islamabad's legitimate security interests in having a friendly western neighbor. ${ }^{81}$ Obama Administration officials have sought to ease India's fears by assuring New Delhi that it has a legitimate role to play in Afghanistan and that the United States does not view regional relationships as a zero-sum game.

Still, the perception among some observers that the United States is in some way planning to abandon Afghanistan elicits great anxiety in New Delhi and fears of a Taliban role in a future Kabul government, with the attendant possibility that Afghanistan could again become a haven for anti-India militants. Even without this worst-case outcome, a U.S. withdrawal and deterioration of security would likely jeopardize India's role and standing in Afghanistan. New Delhi's leaders may not yet have a coherent plan for this possibility. According to one senior analyst, "So far, India's plans consist largely of hand-wringing and facile hopes." A presumed lack of U.S. consultation with India previous to President Obama's June 2011 drawdown announcement left some in India dubious about a U.S.-India partnership that did not (in their view) give sufficient consideration to India's security concerns about a potential future governance role for Afghan Taliban elements. Leaked U.S. diplomatic cables reportedly support the notion that New Delhi has been anxious about the implications of a U.S. withdrawal. ${ }^{82}$

\section{India-China Relations: Asia's Titanic Rivalry? ${ }^{83}$}

\section{Background and Context}

India and China together account for one-third of the world's population, and are seen to be rising $21^{\text {st }}$ century powers and potential strategic rivals. As India has sought to expand its strategic horizons in recent years - eyeing influence over a vast region from Iran and the Persian Gulf states in the west to the Straits of Malacca and Gulf of Thailand and perhaps even the South China Sea in the east - it increasingly finds itself bumping into a spreading Chinese presence in the same area. New Delhi fears "encirclement" by Beijing, and many analysts view the Indian Ocean Region (IOR) as a key stage upon which $21^{\text {st }}$ century geopolitical power struggles will

\footnotetext{
${ }^{80}$ See, for example, Frederic Grare, "Pakistan," in Ashley Tellis and Aroop Mukharji, eds., Is a Regional Strategy Viable in Afghanistan?, Carnegie Endowment for International Peace, May 2010. Islamabad fears strategic encirclement and takes note of India's past support for Afghan Tajik and Uzbek militias who fought against the Pakistan-supported Taliban during the 1990s.

${ }^{81}$ General Stanley McCrystal's August 30, 2009, assessment at http://media.washingtonpost.com/wp-srv/politics/ documents/Assessment_Redacted_092109.pdf.

${ }^{82}$ Quote from Sumit Ganguly, “Afghanistan Is Now India’s Problem,” Foreign Policy (online), July 19, 2011; M.K. Bhadrakumar, "Taliban's Return and India's Concern" (op-ed), Hindu (Chennai), June 28, 2011; documents discussed in B. Muralidhar Reddy, “Don't Leave Afghanistan, India Told U.S.” (op-ed), Hindu (Chennai), May 24, 2011.

${ }^{83}$ See also CRS Report R41108, U.S.-China Relations: Policy Issues, by Susan V. Lawrence and Thomas Lum.
} 
play out. ${ }^{84}$ Some further encourage Washington to leverage its own relationship with the region's leading pluralistic democracy to "set limits on Chinese expansion," perhaps especially through increased joint naval coordination. ${ }^{85}$ Meanwhile, some strategic thinkers in India worry that the United States is on a path of engagement with China that could threaten Indian interests and relegate India to a secondary role in Asia. ${ }^{86}$

India and China fought a brief but intense border war in 1962 that left China in control of large swaths of territory still claimed by India. Today, India accuses China of illegitimately occupying nearly 15,000 square miles of Indian territory in Kashmir (the Aksai Chin region), while China lays claim to 35,000 square miles in the northeastern Indian state of Arunachal Pradesh. The 1962 clash ended a previously friendly relationship between the two leaders of the Cold War "nonaligned movement" and left many Indians feeling shocked and betrayed. ${ }^{87}$ While some aspects of India-China relations, including bilateral trade, have warmed measurably in recent years, the two countries have yet to reach a final boundary agreement. Adding to New Delhi's sense of insecurity have been suspicions regarding China's long-term nuclear weapons capabilities and strategic intentions in South and Southeast Asia. A strategic orientation focused on China appears to have affected the course and scope of New Delhi's own nuclear weapons, ballistic missile, and other power projection programs.

During a landmark 1993 visit to Beijing, Prime Minister Narasimha Rao signed an agreement to reduce troops and maintain peace along the Line of Actual Control (LOAC) that divides the two countries' forces at the disputed border. Numerous rounds of border talks and joint working group meetings aimed at reaching a final settlement have been held since 1981-13 of these since both countries appointed special representatives in 2003 - with New Delhi and Beijing agreeing to move forward in other issue-areas even as territorial claims remain unresolved.

Beijing's military and economic support for Pakistan — support that is widely understood to have included nuclear weapons- and missile-related transfers - is a major and ongoing source of bilateral friction. Past Chinese support for Pakistan's Kashmir position, along with more recent reports of a Chinese military presence in Aksai Chin, have added to the discomfort of Indian leaders. There have been reports of links between Chinese intelligence agencies and insurgent

\footnotetext{
${ }^{84}$ Analysts taking a "realist" political perspective view China as an external balancer in the South Asian subsystem, with Beijing's material support for Islamabad allowing Pakistan to challenge the aspiring regional hegemony of a more powerful India. More wary observers, especially in India, see Chinese support for Pakistan as a key aspect of Beijing's perceived policy of "encirclement," or constraint, of India as a means of preventing or delaying New Delhi's ability to challenge Beijing's region-wide.

${ }^{85}$ Robert Kaplan, "Center Stage for the Twenty-First Century," Foreign Affairs, March/April 2010. Some observers see American neoconservatives pushing for development of a U.S.-India military alliance as a direct counter to China's rise, but warn that such an objective risks polarizing Asia in ways that would ultimately harm U.S. interests and constrain Washington's policy flexibility in addressing the region's myriad issues (Robert Dreyfuss, "India Eyed for US Great Wall Plan?," Diplomat (Tokyo), November 19, 2010).

${ }^{86}$ So deep are the concerns among some Indian commentators that fears of a developing "U.S.-China-Pakistan nexus" have been expressed (G. Parthasarathy, "The Axis of Grudging Cooperation" (op-ed), Wall Street Journal, May 4, 2010).

${ }^{87}$ Shortly after Indian Independence in 1947, India and China enjoyed a brief period of close relations. This soon began to break down as China sought to renegotiate the border between the two countries because it viewed the border as a colonial legacy. India has taken the position that the post-independence Indian state has assumed the "McMahon line" border established under the British Raj at the Simla conference of 1913, which generally follows the crest line of the Himalaya mountains (Karunakar Gupta, “The McMahon Line 1911-45: The British Legacy," China Quarterly, September 1971).
} 
groups in India's northeast. ${ }^{88}$ India and China also have competed for trade partners and energy resources in other developing regions to feed their rapidly growing economies; India's relative poverty puts New Delhi at a significant disadvantage in such competition. ${ }^{89}$

The Chinese are increasingly wary over the growing strategic relationship between the United States and India, and Beijing has expressed concern over potential alignments in Asia that could result in the "encirclement" of China. Chinese concern in this regard was made evident when Beijing protested discussions under the Bush Administration to develop a quadrilateral group of like-minded democracies in Asia that would include the United States, Japan, Australia, and India. Still, while Indians can at times appear to be obsessed with comparisons to China, the Chinese are generally far more complacent, giving the rivalry an appearance of one-sidedness. ${ }^{90}$

China is also particularly sensitive to India's influence in Tibet. India allows the Dalai Lama to live in India and has allowed him to visit India's Arunachal Pradesh state abutting Tibet. ${ }^{91}$ The Indian territory of Ladakh, which is near the Chinese-held, Indian-claimed territory of Aksai Chin, is also ethnically Tibetan. ${ }^{92}$ Nonetheless, India is particularly sensitive to the development of U.S.-China relations, especially as they pertain to South Asia. This was evident as India railed at a clause in the 2009 U.S.-China Joint Statement that called for Washington and Beijing to "work together to promote peace, stability, and prosperity in South Asia.",93

Despite the anxieties elicited by the now simultaneous rise of Asia's two largest countries, New Delhi calls its relationship with Beijing a "priority" and asserts that the two countries have "stepped up functional cooperation in all areas, including efforts to build military-to-military trust and confidence through bilateral defense interactions" that are "growing." It also notes ongoing bilateral cooperation in areas such as finance, agriculture, water resources, energy, environment, tourism, and information technology, along with joint efforts in multilateral fora on global issues such as trade negotiations and energy security, which includes "cooperating very closely" on climate change issues. ${ }^{94}$ Both governments have hailed their "strategic and cooperative partnership" which, according to New Delhi, has established important confidence-building measures and broadened people-to-people contacts. ${ }^{95}$

\footnotetext{
${ }^{88}$ Lyle Morris, "Is China Backing Indian Insurgents?," Diplomat (Tokyo), March 22, 2011.

${ }^{89}$ An example is found in relations with Africa, where India's historical advantage has been eroded by Beijing's deeper pockets. The value of China's two-way trade with African countries has been than double that of India's.

90 “India Measures Itself Against a China That Doesn't Notice," New York Times, August 31, 2011.

${ }^{91}$ Beijing was openly displeased when New Delhi allowed the Dalai Lama to visit the disputed Arunachal Pradesh state in late 2009, saying the travel further revealed that figure's "anti-China and separatist essence" (Chinese Foreign Ministry spokesman quoted in "China Opposes Dalai Lama Trip to Disputed Indian State," Reuters, September 11, 2009).

${ }^{92}$ Reports that Chinese military units began building infrastructure in the Karakoram mountains of Jammu and Kashmir's Ladakh region in 2009 raise further security concerns in New Delhi ("Construction by Chinese Army Across Karakoram: J\&K Report,” Times of India (Delhi), September 14, 2009).

${ }^{93}$ See the text of the November 17, 2009, Joint Statement at http://www.whitehouse.gov/the-press-office/us-chinajoint-statement. See also "Stabilize South Asia," Harvard International Review, Winter 2010.

${ }^{94}$ Indian Ministry of External Affairs, "India-China Bilateral Relations," September 2010 and August 2011.

${ }^{95}$ See the April 7, 2010, Ministry of External Affairs release at http://meaindia.nic.in/mystart.php?id=530315707.
} 


\section{India-China Commercial Relations}

China has in recent years overtaken the United States as India's leading trade partner. The value of India-China trade surpassed $\$ 62$ billion in 2010, up an impressive 43\% over the previous year. China is the single largest source of imports for India, accounting for above $\$ 40$ billion worth or more than 11\% of all imports in FY2010/11. China is also the third largest export market for Indian goods (behind the United Arab Emirates and United States), accounting for \$19.4 billion worth or about $7.7 \%$ of all exports in FY2010/11. ${ }^{96}$ Yet the course of the bilateral trade relationship may not favor India over the middle- and long-term, given clear signs of both qualitative and quantitative imbalances. China now accounts for nearly one-fifth of India's total trade deficit. Roughly half of India's electronics imports come from China, along with nearly onequarter of machinery products imports and about one-sixth of total steel imports. Meanwhile iron ore is by far the leading Indian export to China, accounting for nearly half of the total value in recent years. India has not yet been able to exploit its advantages in the services sector, and many analysts see China trade as an area in which India can at least partially mitigate its badly lagging manufacturing sector.

Numerous large state-owned Chinese companies have operations in India, especially in power generation, and machinery and infrastructure construction. The cumulative value of contractual Chinese investment projects in India is nearly $\$ 30$ billion. Indian companies also operate in China, notably in the manufacturing, information technology, and banking sectors, but the degree is far more modest at less than $\$ 1$ billion cumulatively. ${ }^{97}$

\section{Is There a Chinese "String of Pearls" Strategy in the Indian Ocean?}

There are mounting fears among some in India that China is encroaching upon what New Delhi sees as its legitimate sphere of influence in South Asia. This concern focuses especially on China's construction of port facilities in the IOR, which has elicited a debate over Beijing's future intentions and concerns that it may seek to interdict or dominate sea lines of communication (SLOCs) there. In 2004, a Washington, DC-based consultancy firm identified China's involvement in developing major new ports in Pakistan (at Gwadar), Sri Lanka (at Hambantota), and Bangladesh (at Chittagong) as representing a potential "string of pearls" strategy which some strategic analysts and media commentators point to as evidence of Beijing's aim to encircle India with naval bases. In mid-2010, Chinese warships docked for a first-ever visit to Burma's Thilawa port. China's plans to develop an overland transportation and energy link from the northern reaches of the Bay of Bengal through Burma to Yunnan is another aspect of this perceived strategy. Port access to the Indian Ocean's strategically vital SLOCs does appear to be a source of considerable rivalry: For example, India desires to see Iran's Chabahar port grow in importance as a transit point into Central Asia that would bypass Pakistan. China, meanwhile, looks to Pakistan's Gwadar port as providing a major future land-line for energy and other supplies to East Asia that would reduce Chinese dependence on Indian Ocean and Malacca Straits sea lanes. ${ }^{98}$

Some analysts dismiss Indian fears as overwrought and note that China does not have the capability to project significant naval power into the IOR. Others take a longer view and see

\footnotetext{
${ }^{96}$ Indian Ministry of Commerce and Industry, Department of Commerce trade data.

${ }^{97}$ Indian Ministry of External Affairs, "India-China Bilateral Relations," August 2011.

${ }^{98}$ See "India, China Rivalry and a Tale of Two Ports," Reuters, March 25, 2011.
} 
present developments as part of a long term strategic plan that will give the Chinese the necessary logistical infrastructure in the IOR to secure its SLOCs to the energy rich Persian Gulf. If developed, this infrastructure could give China a strong naval position relative to India in the IOR, though this will likely take decades to develop. China only just sent its first aircraft carrier out for sea trials in August 2011. The U.S. Department of Defense, in its most recent (August 2011) assessment of Chinese military capabilities, noted Beijing's civilian port projects in the IOR and their potential to improve China's peacetime logistical support options, but also contended that Beijing's power projection abilities in the region will remain limited in the absence of overseas military bases. ${ }^{99}$

China has no naval bases in the IOR at present, and available evidence suggests that Beijing's "string of pearls" strategy is in an embryonic phase. Some analysts encourage stronger U.S.-India strategic and military ties with an eye specifically on preventing China from dominating the region and its sea lanes. ${ }^{100}$ Others contend that a (limited) Chinese navy presence in the Indian Ocean is not inherently illegitimate or threatening. Some are relatively sanguine that, even if the Chinese navy were to establish overtly military posts on the Indian Ocean in the future, India would still enjoy considerable geographic and logistical advantages in the case of open conflict. Such advantages could be built upon with some fairly facile Indian policies, including reinforcing its Andaman and Nicobar Command, which could present a sturdy "barrier" to hostile forces entering the Bay of Bengal from the east, and expanding maritime intelligence-sharing with the United States. ${ }^{101}$ A strong Indian naval presence near the entrance to the Strait of Malacca would be well positioned to interdict Chinese shipping in the event of conflict.

\section{Recent Developments}

Tensions between India and China appear to have increased over the past year despite a 30-fold jump in the value of their bilateral trade over the past decade. Many commentators are speculating that a new "Great Game" is unfolding between Asia's two largest countries, perhaps to be centered on Kashmir, and that the bilateral relationship "has begun to take the form of a true geopolitical rivalry." 102 In 2009, India added two full army divisions to those already deployed near the disputed border, built at least three new airstrips in the region, and moved two squadrons of advanced Sukhoi-30 MKI combat aircraft to a base in the nearby Assam state. The latter months of 2009 saw New Delhi and Beijing engage increasingly vituperative diplomatic and media barbs, placing U.S. officials in something of a dilemma over how to maintain friendly relations with both countries. China's 2010 decision to issue special visas to Indian citizens from Arunachal Pradesh and Jammu and Kashmir reflected Beijing's official position that residents of these states have different status than other Indians, a position that obviously antagonizes India. ${ }^{103}$

\footnotetext{
${ }^{99}$ See http://www.defense.gov/pubs/pdfs/2011_cmpr_final.pdf.

${ }^{100}$ See, for example, Lisa Curtis and Dean Cheng, "The China Challenge: A Strategic Vision for U.S.-India Relations," Heritage Foundation Backgrounder No. 2583, July 18, 2011.

${ }^{101}$ Iskander Rehman, "China's String of Pearls and India's Enduring Tactical Advantage," Institute for Defense Studies and Analyses (Delhi), June 8, 2011; see also Vivian Yang, "Is China's String of Pearls Real?," Institute for Policy Studies, July 18, 2011.

102 "Mountains to Climb: China's Complex Relationship with India," Jane's Intelligence Review, May 7, 2010.

${ }^{103}$ A small-sample, late 2010 opinion survey of Arunachal Pradesh residents found an overwhelming $95 \%$ wanting the state to be a part of India and $80 \%$ wanting Hindi to be the state's official language (India Today-Synovate survey results in "The Truth is Out There," India Today (Delhi), December 27, 2010).
} 
Meanwhile, the unresolved border dispute is seen to be a significant obstacle to expanded IndiaChina economic and trade relations, and some analysts see Beijing's Kashmir stance becoming more adversarial, as was the case in the past, perhaps even more hostile to India than is Islamabad's. ${ }^{104}$ Indian sources have accused Chinese patrols of "transgressing" the LOAC - an average of about ten such incursions per month was reported in 2008 - and periodic reports of incursions continue. Official Chinese news outlets at times accuse the Indian media of issuing "war rhetoric" and "sowing the seeds of enmity" with reports of Chinese "intrusions" across the LOAC ${ }^{105}$ Earlier in 2011, Indian military officials issued statements that the alleged presence of Chinese troops in Pakistan-held Kashmir poses a serious military challenge to India. Beijing denies reports of a Chinese military presence in Kashmir. ${ }^{106}$

In August 2010, three separate episodes illuminated ongoing frictions. First, New Delhi and Beijing exchanged sharp diplomatic words after China refused to issue a visa to the Indian general responsible for Indian Kashmir. Later, India reportedly moved to counter the alleged deployment of advanced Chinese missiles to the border area with its own plans to place intermediate-range Agni II and short-range Prithvi III missiles near the frontier. Finally, two Chinese warships paid a first-ever port visit to Burma, exacerbating fears among some that Chinese naval power was being wielded too closely to Indian shores. ${ }^{107}$ In September 2010 , Prime Minister Singh reportedly warned that China "would like to have a foothold in South Asia." Only days earlier, External Affairs Minister Krishna opined that China had been showing "more than the normal interest in the Indian Ocean affairs. So we are closely monitoring the Chinese intentions." 108

While few Indian decision makers are desirous of direct conflict with China, there seems to be an upswing in negative views about Beijing's evolving regional and global role, with misgivings perhaps arising along a perspective that New Delhi's past policies have been too concessionary in dealing with a China that may increasingly be perceived as "an erratic, ultra-nationalist state that seeks to constrain India." ${ }^{\prime 109}$ The pessimistic Indian perspective sees Beijing as unworthy of New Delhi's trust and so rejects the Chinese government's rhetorical commitment to cooperation and dispute resolution as bromides veiling more nefarious intent. ${ }^{110}$

While there are causes for concern in the India-China relationship, there are also some new areas of convergence between the two states, as was made evident when the two governments closely coordinated their positions in the lead up to the Copenhagen Conference on climate change. The potential for future renewed conflict between India and China warrants a close watch as the

104 “C. Raja Mohan, “India Worried Over China’s New J\&K Line” (op-ed), Indian Express (Delhi), October 14, 2010.

105 "Fresh Chinese Incursions Across LAC," Times of India (Delhi), September 10, 2008; "Indian Media Engaging in War Rhetoric: Chinese Paper," Hindustan Times (Delhi), September 10, 2009.

106 “General Alert: Chinese Troops on Indo-Pak LoC," Hindustan Times (Delhi), April 5, 2011; Chinese foreign ministry spokeswoman quoted in "China Rejects Reports of Presence of Chinese Troops in PoK," Press Trust of India, April 7, 2011.

107 “India-China Relations Hit By Defense Row,” Agence Presse France, August 27, 2010; “India Responds to Chinese Missile Moves," Jane's Defense Weekly, August 26, 2010; "China Warships Dock in Burma, Rattling Rival Naval Power India," Christian Science Monitor, August 30, 2010.

${ }^{108}$ Singh quoted in "India PM Warns China Wants Foothold in South Asia," Reuters, September 7, 2010; "India Monitoring China's Intention in Indian Ocean, Says Krishna," Hindu (Chennai), September 1, 2010.

${ }^{109}$ Sujit Dutta, “Managing and Engaging Rising China: India’s Evolving Posture,” Washington Quarterly, Spring 2011.

${ }^{110}$ A representative explication is Harsh Pant, "China and India: A Rivalry Takes Off," Foreign Policy Research Institute E-Notes, June 2011. 
correlates of power and strategic architectures evolve in Asia. Yet, while tensions appear to mount, neither country is likely to seek open conflict as both have made economic development their key national priority.

From this perspective, increased economic interdependence will act as an inhibitor to conflict, but the workings of this dynamic are not so clear. Some analysts also note that the nature and imbalance of the dramatically growing trade between India and China is leading to a degree of mutual antagonism over the trade relationship. Yet China arguably faces strong disincentives to behave aggressively in the IOR given that doing so would be likely to accelerate India's partnership with the United States, and that any open conflict in the region could cause potentially major harm to the Chinese economy. The argument is thus that incentives for India and China to cooperate are strong. ${ }^{111}$ In a sign that recent India-China animosity may have crested, Indian National Security Advisor Shiv Shankar Menon announced in April 2011 that the two countries had agreed to restore suspended defense ties, take steps to enhance their balance of trade, and establish a new consultation mechanism to address border disputes. ${ }^{112}$

\section{India's Other Regional Foreign Relations}

\section{India-Sri Lanka ${ }^{113}$}

India's relationship with the island nation of Sri Lanka dates back millennia and is marked by intimate cultural, religious, and linguistic interaction. For most of the past three decades, relations have been dominated by the now-concluded Sri Lankan civil war between Colombo's government forces and the Liberation Tigers of Tamil Eelam (LTTE). Sri Lanka is divided between a largely Sinhalese-Buddhist majority in the south, which dominates the government, and a Hindu-Tamil minority in the north and east. The still-unresolved ethnic conflict has complicated the relationship between India and Sri Lanka due to the presence in south India of a large Tamil minority of more than 60 million (mainly the state of Tamil Nadu). Some strategic analysts in India are concerned by increased Chinese activity in Sri Lanka.

Domestic sentiment and increased flows of refugees led India to intervene in the conflict in 1987 by sending a large Indian Peace Keeping Force to Sri Lanka to establish order and disarm Tamil militants. Former Indian Prime Minister Rajiv Gandhi was assassinated by an LTTE suicide bomber in 1991. India later withdrew its forces after they suffered some 1,000 deaths, and it subsequently refrained from direct involvement in the conflict. New Delhi did, however, continue to acknowledge Colombo's right to act against "terrorist forces."

The mid-2009 end of combat in Sri Lanka opened the way for newly deepened bilateral relations. New Delhi offered an immediate \$115 million grant and provided other support to assist in dealing with the resulting humanitarian crisis and resettlement of hundreds of thousands of internally displaced persons. During a mid-2010 visit to India, Sri Lankan President Mahinda Rajapaksa agreed with Prime Minister Singh that the two countries' "vibrant and multi-faceted partnership" warranted agreements on social, legal, and women's affairs, energy and

\footnotetext{
${ }^{111}$ Ryan Clarke, "Sino-Indian Strategic Relations: Constrained Competition, Constrained Cooperation," National University of Singapore East Asia Institute Background Brief No. 612, April 1, 2011.

112 “India, China Take Steps to Ease Disputes, Enhance Trade," Reuters, April 13, 2011.

${ }^{113}$ See also CRS Report RL31707, Sri Lanka: Background and U.S. Relations, by Bruce Vaughn.
} 
transportation, as well as a soft loan of $\$ 800$ million for the reconstruction of a northern railway that was destroyed during the war. ${ }^{114}$ The total value of bilateral trade exceeded $\$ 3$ billion in 2010, up some 47\% over the previous year. Indian defense ties with Sri Lanka have been revived. New Delhi today contends that relations with Colombo are "strong and poised for a quantum jump." 115

Yet India remains concerned with the situation in Sri Lanka even after the end of open hostilities there. Members of India's Parliament worry that Indian aid intended for displaced Tamils has not reached the targeted community. Then-Foreign Secretary Rao traveled to Sri Lanka as Special Emissary in 2010 to assess rehabilitation efforts, reportedly conveying to Colombo India's hope that Sri Lanka would initiate a political process to resolve the underlying ethnic issues that fueled the previous civil war in addition to resettling and rehabilitating displaced Tamils. ${ }^{116}$ New Delhi continues to emphasize its view that Sri Lanka's national reconciliation must come through a negotiated political settlement of ethnic issues that is "acceptable to all communities within the framework of a united Sri Lanka and which is consistent with democracy, pluralism, and respect for human rights." In meetings with Sri Lanka's President in June 2011, three top Indian officials asked that his government move quickly to reach a political settlement with the Tamils. ${ }^{117}$

A 2011 report by the Brussels-based International Crisis Group acknowledged New Delhi's "active engagement and unprecedented financial assistance" in Sri Lanka, but contends that India's policies have failed to date in facilitating a sustainable peace on the island. The report urges the Indian government to work more closely with the United States, European Union, and Japan in pressing Colombo to negotiate a political settlement to Sri Lanka's ethnic disputes, in part by lifting blanket emergency rule, re-establishing civil administration in Tamil-majority areas, and taking other democratizing and reconciliatory actions. Some independent analysts likewise convey a perception that India has done too little to foster democracy, ensure that ethnic minority rights are respected, and hedge against growing Chinese influence in Sri Lanka. ${ }^{118}$

\section{India-Bangladesh ${ }^{119}$}

India shares close historical, cultural, linguistic, social, and economic ties with neighboring Bangladesh, a country also born of colonial British India. However, and despite India's key role in the 1971 "liberation" of the former East Pakistan, New Delhi's past relations with Dhaka have been fraught with tensions related mainly to the cross-border infiltration of Islamist and separatist militants, and to the tens of millions of illegal Bangladeshi migrants in India. The two countries share a heavily-populated, 2,540-mile-long border, the great majority of which New Delhi has attempted to seal through fence construction. The two countries' border forces have in the past engaged in sometimes lethal gun battles, and Bangladesh-based terrorists groups have been active

\footnotetext{
${ }^{114}$ See the June 12, 2010, Joint Declaration at http://meaindia.nic.in/mystart.php?id=530515869.

115 “India-Sri Lanka Relations,” Ministry of External Affairs document, July 2011.

116 "India Pushes Sri Lanka on Political Settlement," Hindustan Times (Delhi), September 2, 2010.

117 “India-Sri Lanka Relations,” Ministry of External Affairs document, July 2011; “India Pushes Sri Lanka on Tamil Rights," Agence France Presse, June 11, 2011.

118 "India and Sri Lanka After the LTTE," International Crisis Group Asia Report No. 206, June 23, 2011; Sadanand Dhume, “India's Sri Lanka Problem” (op-ed), Wall Street Journal, July 20, 2011.

${ }^{119}$ See also CRS Report R41194, Bangladesh: Political and Strategic Developments and U.S. Interests, by Bruce Vaughn.
} 
inside India. ${ }^{120}$ Still, New Delhi and Dhaka have cooperated on joint counterterrorism efforts and talks on extensive energy cooperation continue. In 2010, India extended a $\$ 1$ billion line of credit to Bangladesh to aid infrastructure development there, and New Delhi offers rice supplies at below-market prices. The value of bilateral trade was about $\$ 3.5$ billion in 2009/2010, up more than $12 \%$ over the previous fiscal year. ${ }^{121}$

India-Bangladesh ties improved markedly after 2008, facilitated by the election that year of Bangladeshi Prime Minister Sheikh Hasina, whose Awami League has historically closer ties to India than does the opposition Bangladesh National Party. New Delhi has lauded the restoration of multi-party democracy in Dhaka. During her 2010 visit to India, Hasina — accompanied by a 123-person delegation and 50-member business contingent - agreed with Prime Minster Singh to put in place "a comprehensive framework of cooperation for development between the two countries," and signed a number of agreements, including pacts on cultural exchange, security, crime prevention, and power supply. India is also allowing increased trade access for Bangladesh across Indian territory to Bhutan and Nepal. ${ }^{122}$

External Affairs Minister Krishna was in Bangladesh in July 2011 for what he called a "very productive" visit marked by the signing of two new trade and commerce agreements, along with "significant forward movement" in bilateral power sector cooperation. However, Prime Minister Singh made some badly-timed remarks posted on an Indian government website: Just before his Krishna arrived in Dhaka, Singh claimed that "at least 25\%" of Bangladeshis "swear by Jamaat-eIslami [Bangladesh's largest Islamist political party] and are very anti-Indian." The comment was widely reported in Bangladesh and contributed to straining relations. ${ }^{123}$

Prime Minister Singh is scheduled to visit Bangladesh in September 2011. This will be the first such travel in 12 years. The visit is expected to develop ties between the two nations and help resolve differences over border disputes, trade, and water issues. There reportedly are 162 disputed enclaves on both sides of the border. The visit will also offer the two leaders the opportunity to discuss shared challenges arising from global climate change. ${ }^{124}$ Some observers see India developing east-west connectivity with Bangladesh to facilitate links with both its own isolated northeastern states and Southeast Asia, as well as with Bangladesh. A few express concern that Bangladesh's expanding ties with China could facilitate Beijing's north-south connectivity with the Indian Ocean littoral at the expense of India. ${ }^{125}$

Cross-border issues and the use of Bangladesh territory by insurgents in India's northeast remain key for New Delhi. A Joint Boundary Working Group established in 2000 met for the fourth time in late 2010, but demarcation disputes remain unresolved in numerous sectors. ${ }^{126}$ Human rights

\footnotetext{
${ }^{120}$ For example, the Bangladeshi faction of the Harakat ul-Jihad-I-Islami-an Islamist militant outfit with links to Pakistan-based terrorist groups and that is designated as a Foreign Terrorist Organization under U.S. law-has been implicated in several terrorist attacks inside India, including May 2008 bombings that killed at least 63 people in Jaipur, Rajasthan.

121 “India-Bangladesh Relations," External Affairs Ministry document, July 2011.

${ }^{122}$ See the January 12, 2010, Joint Communiqué at http://meaindia.nic.in/mystart.php?id=530515482.

123 "Remarks by EAM at the Joint Press Interaction in Dhaka," Ministry of External Affairs transcript, July 7, 2011;

"Indian PM Makes 'Off -the-Record' Bangladesh Swipe,” Agence France Presse,” July 2, 2011.

124 "India and Bangladesh Aim to End Border Anomalies," Irish Times (Dublin), September 6, 2011; P. Pandey, "IndiaBangladesh Relations: Need for New Approach," RSIS Commentaries, September 5, 2011.

125 “As India's Singh Heads for Bangladesh, China Looms Large,” Reuters, September 2, 2011.

126 "Meeting of the India-Bangladesh Joint Boundary Working Group," Indian Ministry of External Affairs press (continued...)
} 
watchdogs have been critical of what they call the "shoot-to-kill" policy of India's border security forces, who reportedly have killed nearly 1,000 people, most of them unarmed Bangladeshis, who attempted to cross the border illegally over the past decade. The issue has become a sore point for Dhaka; Bangladesh's foreign minister has urged Indian border security forces to exercise "utmost restraint" and was assured by her Indian counterpart that steps were being taken to address the problem. ${ }^{127}$ Prime Minister Hasina has discussed with Prime Minister Singh her government's crackdown on Bangladesh-based Indian separatists, and reportedly made a commitment that she would not allow Bangladesh territory to be used for anti-Indian activities. ${ }^{128}$ Hasina's government reportedly arrested and handed over to India a key leader of the United Liberation Front of Assam early in 2010, then later in the year remanded to India 28 leaders of the United Liberation Front of Assam (ULFA). Dhaka's efforts to crack down on Indian separatist militants there apparently has led many of those elements to relocate to Burma. ${ }^{129}$

Improved ties with Bangladesh can provide India with an opportunity to counter Pakistani and Chinese influence there. China has been assisting Bangladesh in developing port facilities in Chittagong, and some Indian sources believe Pakistan's main intelligence agency has used Bangladesh to infiltrate operatives and even "terrorists" into India. In October 2010, Bangladesh formally sought Chinese assistance to build a deep water sea port in the Bay of Bengal near the southeastern island of Sonadia. The Dhaka government hopes that such a port could become a key shipping hub for northeast India and China's Yunnan Province, as well as for Nepal, Bhutan, and Burma. Bangladesh is also reportedly in discussion with China and Burma on plans to build a highway linking Bangladesh's Chittagong with Kunming, the capital of China's Yunnan Province. Such connectivity with China would likely be an issue of concern for India. India's multi-billiondollar transit projects could go far in bringing development to isolated regions of both countries, but some in Dhaka worry that India intends to create a "security corridor" across Bangladesh to supply counterinsurgency forces in its northeastern states and potentially even defense forces facing China in Arunachal Pradesh, which could elicit reprisals from Beijing. ${ }^{130}$

\section{India-Nepal ${ }^{131}$}

India-Nepal relations traditionally have been close and come under the aegis of the 1950 IndoNepal Peace and Friendship Treaty, which allows for unrestricted travel and residency across their 1,150-mile-long shared border. From New Delhi’s view, the Treaty affords Nepali citizens "unparalleled advantages in India," and has "enabled Nepal to overcome many of the

(...continued)

release, November 11, 2010. See also "Why India Offers Tepid Response to Burma's Release of Suu Kyi," Christian Science Monitor, November 22, 2010.

${ }^{127}$ Brad Adams, "India's Shoot-To-Kill Policy on the Bangladesh Border," Guardian (London), January 28, 2011; "Dhaka Asks India to Exercise Restraint on Border," Hindu (Chennai), February 8, 2011; "India: New Killings, Torture at Bangladeshi Border," Human Rights Watch release, July 25, 2011.

128 "Eastern Entente," India Today (Delhi), January 25, 2010. Previously, Dhaka had taken action against some of the "terrorist camps" on Bangladeshi soil identified by Indian intelligence officials and assured New Delhi that it would not tolerate the presence of anti-India groups ("Mending Fences," India Today (Delhi), September 21, 2009).

129 "India's Opening with Bangladesh," New York Times, January 12, 2010; "ULFA Strike Force Leaders in Security Net," Economic Times (Delhi), September 26, 2010; "Northeast Militants Shifting to Myanmar from Bangladesh," Indo-Asian News Service, September 3, 2010.

130 “Embraceable You,” Economist (London), July 30, 2011.

${ }^{131}$ See also CRS Report RL34731, Nepal: Political Developments and Bilateral Relations with the United States, by Bruce Vaughn. 
disadvantages of being a landlocked country." 132 India remains in close consultation with the Nepali government in an effort to support Nepal's transition to a democratic, peaceful, and prosperous state. Prime Minister Singh conveyed his "warmest felicitations" to newly elected Nepali Prime Minister Baburam Bhattarai in August 2011. Bhattarai received his doctorate degree from New Delhi's Jawaharlal Nehru University. ${ }^{133}$ Nepal is the world's only officially Hindu country, and India continues to be its leading trade partner, as well as source of foreign investment and tourist arrivals. India has taken a lead role in efforts to train and equip the Nepal Army. ${ }^{134}$ The Madhesh people of Nepal's Terai region bordering India share the Hindi language, as well as many familial ties across the open border. The largely Hindu social and religious structure of Nepal makes Nepali culture similar to India's in many respects.

The bilateral relationship is driven by two major geopolitical considerations. First, Nepal is viewed as a "buffer state" between India and China. As such, India seeks to minimize (or at least balance against) Chinese influence there. The substantial Tibetan community in Nepal can at times complicate this dynamic. While the Kathmandu government allows Tibetans to live in Nepal, it has a policy of not allowing any "anti-China" activity inside Nepal. Nepali authorities prevented the election of a Tibetan community government-in-exile in October 2010, a step taken by some as a hardening of Kathmandu's stance toward Tibetan refugees. ${ }^{135}$ Tibetan protests in Nepal in the lead-up to the 2008 Beijing Olympics had also led to a crackdown by Nepali authorities. There is growing evidence of Chinese ties with Nepali Maoists. A high profile bribery case alleges that a Maoist leader asked a Chinese official for substantial amounts of money to influence Madheshi lawmakers in support of the Maoist's bid for the prime ministership. Former Nepali Prime Minister Prachanda traveled to China at least four times. Current Prime Minister Bhattarai, also of the CPN-M, has stated that Nepal needs to be sensitive to the security concerns of both India and China. Prachanda was viewed by some as having tilted towards China. India reportedly was "deeply uncomfortable with and suspicious of Maoist intentions" under the previous Prachanda government. Bhattarai has reportedly offered that "the days of playing India and China are over." 136

The second key Indian geopolitical interest in Nepal is to maintain political stability in Kathmandu and keep Nepal from becoming a base of support for insurgents in India. India is concerned that a Maoist government in Nepal could lend support to the already significant Maoist insurgency in India. Thus far, there have been only limited connections between these groups, but it appears that India is concerned the links could grow should the Maoists assert their dominance over Nepal. Political stability in Nepal could lead to infrastructure development and the establishment of major new projects to tap the country's estimated 43,000 megawatts of hydropower potential that is seen to be technically feasible and economically viable. ${ }^{137}$ This could go far in addressing the growing energy needs of India's northern states.

\footnotetext{
${ }^{132}$ While Kathmandu has over the years expressed a desire to revise the Treaty, specific suggestions about doing so "have not been forthcoming" from the Nepali side ("India-Nepal Relations," Ministry of External Affairs document, March 2011).

133 “PM’s Good Wishes for New Nepal PM” Times of India (Delhi), August 31, 2011.

134 “India-Nepal Relations,” External Affairs Ministry document, March 2011.

135 "Nepal Stops Voting for Tibetan Government in Exile," Hindustan Times (Delhi), October 4, 2010.

${ }^{136}$ Nepal Wont Jeopardise Any Genuine Indian Interest," Hindu (Chennai), September 3, 2011; "India Suspected Nepal Maoist Faith in Multi Party Democracy," Times of India (Delhi), September 5, 2011; "New Pragmatic Premier Raises Hopes in Nepal," New Straits Times (Singapore), September 5, 2011.

137 “India-Nepal Relations,” External Affairs Ministry document, March 2011.
} 


\section{India-Burma $^{138}$}

India and Burma share close historical, ethnic, cultural, and religious ties, along with a 1,000mile-long border and maritime proximity in the Bay of Bengal. New Delhi continues to pursue closer relations with the repressive military regime in neighboring Rangoon for both economic and political reasons. India seeks to bolster its energy security by increasing "connectivity" between its northeastern states and western Burma. India is also concerned about the maintenance of political stability in Burma, fearful that instability could result in a surge of refugees into India and a further increase in China's regional influence. New Delhi may also view good relations with Rangoon as a key aspect of its strategy to address ongoing territorial disputes with China and Pakistan. In addition, many observers see past and continued cooperation by the Burmese military as being vital in New Delhi's efforts to battle separatist militants in India's northeast. India was Burma's fourth-largest trading partner in FY2009/10 (after Thailand, China, and Singapore), with total trade of a record $\$ 1.2$ billion, up $27 \%$ over the previous fiscal year. India is engaged in more than a dozen major projects in Burma, most of them related to improving that country's transportation and communication links. ${ }^{139}$

In 2007, Burma's military junta, the State Peace and Development Council (SPDC), launched a violent crackdown to suppress major pro-democracy street protests led by Buddhist monks. In response, the United States imposed new sanctions on Burma and urged other countries to follow suit, yet New Delhi continued to favor dialogue and opposed the imposition of new sanctions. Moreover, during the protests and immediately afterwards, India moved ahead with plans to assist with the construction of a port in northwestern Burma as part of an effort to develop that country's natural gas industry. New Delhi's approach, justified by Indian leaders as being a pragmatic pursuit of their own national interests and as part of their "Look East" policy (see below), elicited accusations of Indian complicity in Burmese repression. ${ }^{140}$ Press reports in late 2007 indicated that New Delhi was halting arms sales to Rangoon; in fact, India's supply of military equipment to Burma was only "slowed." 141

Burma again became the focus of international discussions in early 2010, when the SPDC released new laws governing parliamentary elections to be held later in the year. ${ }^{142}$ The laws appeared to restrict the participation of Burma's opposition parties, in particular the National League for Democracy and its leader, Aung San Suu Kyi. While the United States, the European Union, and others were quick to criticize the laws, India's response was comparatively muted. New Delhi chose to disassociate itself from a June 2010 U.N. Human Rights Council resolution that condemned "ongoing systematic violations of human rights" in Burma. However, as one of 14 countries in the "Group of Friends on Burma"-a consultative body formed by U.N.

\footnotetext{
${ }^{138}$ See also CRS Report R41336, U.S. Sanctions on Burma, by Michael F. Martin.

139 "India-Myanmar Relations," External Affairs Ministry document, February 2011.

140 “India to Push On With Myanmar Port Despite Unrest,” Reuters, October 10, 2007; “India Silent on Myanmar Crackdown," Associated Press, October 23, 2007.

141 “Indian Arms Sales to Myanmar Remain Under Scrutiny," Jane's Defense Weekly, January 16, 2008. In 2006, India transferred to Burma two maritime surveillance aircraft and a number of air defense guns, and the Indian defense minister announced the sale to Burma of more defense equipment - including tanks and heavy artillery - in exchange for Rangoon's counterterrorism cooperation and assistance in neutralizing Indian separatists operating near their shared border ("Why India is Selling Weapons to Burma," Christian Science Monitor, July 23, 2007).

${ }^{142}$ See also CRS Report R41218, Burma's 2010 Elections: Implications of the New Constitution and Election Laws, by Michael F. Martin.
} 
Secretary-General Ban Ki-Moon-New Delhi did support the Group's call for free and fair elections, and for the release of all political prisoners.

In mid-2010, SPDC chief Senior General Than Shwe traveled to New Delhi-his second visit in six years - and met with Prime Minister Singh to discuss bilateral ties. The leaders reportedly discussed matters such as border security, economic relations, and upcoming elections in Burma. There were subsequent reports that the Indian military plan would move additional Border Security Force troops to guard the border with Burma. Even strident boosters of deepening U.S.India relations issued criticisms of New Delhi's "Machiavellian turn" in welcoming the Burmese leader and pursuing greater links with his military regime. Independent analysts also insist that, as perhaps the only external power with the ability to tip the balance in favor of Burma's democratic forces, India has an obligation to look beyond its more mercenary interests to take a more principled stand. ${ }^{143}$

President Obama dismissed Burma's November 2010 elections as having been neither free nor fair. While concurrently visiting New Delhi, the President was openly critical of India's relative silence on the Burmese regime's suppression of democratic movements and violations of human rights, saying democracies with global aspirations have an obligation to condemn such actions. Soon after, an unnamed Indian official said New Delhi has "strategic interests" in Burma and that its policies are driven by "political compulsions." Secretary of State Clinton repeated the U.S. President's contention while in Chennai in mid-2011, expressing her hope that New Delhi would continue pressing Rangoon to move ahead with democratization and contending that India has "the duty to speak out against violations of universal human rights."144

Suu Kyi's November 2010 release from house arrest was officially welcomed by New Delhi with the hope that it would begin a process of reconciliation in Burma; Suu Kyi has herself urged India to play a more active role in standing up for democracy and "look beyond a commercial kind of view" when dealing with Burma. ${ }^{145}$ In June 2011, External Affairs Minister Krishna paid a threeday visit to Rangoon, but did not take the opportunity to meet Suu Kyi (a task undertaken by the Indian foreign secretary).

\section{India-ASEAN}

Initiated by Prime Minister Narasimha Rao in 1991, India's "Look East" policy coincided with the country's economic liberalization and has for two decades reflected New Delhi's focused efforts to deepen commercial and diplomatic relations with East and Southeast Asia. It also has included security cooperation with many of India's eastern neighbors, likely in response to China's growing regional influence. As the ASEAN countries realized significant economic growth, Indian leaders have fairly consistently pursued greater engagement in Southeast Asia. Given the Indian foreign secretary's view that "India is as much a Southeast Asian nation as a

\footnotetext{
${ }^{143}$ Quote from Sumit Ganguly, "India's Machiavellian Turn” (op-ed), Wall Street Journal, July 29, 2010; Timothy Garton Ash, "Step Up, India” (op-ed), Los Angeles Times, November 18, 2010. A notable Indian analyst opined that, by hosting Shwe, India had "drifted a bit too far even by its new standards of realpolitik" (C. Raja Mohan, "Embracing Myanmar: India's Foreign Policy Realism,” RSIS Commentaries, August 2, 2010).

144 “Obama Criticizes India's Silence on Myanmar,” Agence France Presse, November 8, 2010; “India's Myanmar Policy Dictated by Strategy: Official Source," Agence France Presse, November 9, 2010; "Remarks on India and the United States: A Vision for the $21^{\text {st }}$ Century," State Department transcript, July 20, 2011.

145 "Statement by EAM on Release of Daw Aung San Suu Kyi," Ministry of External Affairs transcript, November 13, 2010; "Suu Kyi Prod to Delhi," Telegraph (Kolkata), December 9, 2010.
} 
South Asian nation," New Delhi's policy seeks to "reconnect and reach out in the civilizational space we share with our neighbors."146

Like the United States, India is designated as an ASEAN "Dialogue Partner." At the IndiaASEAN Post-Ministerial Meeting in Indonesia in July 2011, there was unanimous agreement that engagement should be strengthened in the security and economic fields, to include upgraded efforts to combat international terrorism and threats to maritime security, and aspirations to finalize a pending Services and Investment Agreement. New Delhi hopes to boost trade with the ten ASEAN states to $\$ 70$ billion by $2012 .{ }^{147}$ Moreover, India has since 1996 been a member of the ASEAN Regional Forum (ARF), in which 27 member states come together to consult on matters affecting regional peace and security. New Delhi's participation further reflects India's growing engagement with the Asia-Pacific region and tracks well with its Look East policy.

India's Look East Policy may not be entirely welcome by China. New Delhi is reportedly spending \$2 billion to set up a military command in the Andaman Islands located to the northwest of the Strait of Malacca, through which much of China's energy and trade flow. In July, an Indian Navy vessel based in the Andamans reportedly received a warning from the Chinese navy that it was entering Chinese waters as it sailed from Vietnam's Nha Trang port towards Haiphong. Some interpret the presence of Indian naval ships in Vietnam as "possibly the start of an Indian bid for influence in the South China Sea."148

\section{India-Iran $^{149}$}

India's relations with Iran traditionally have been positive and are marked by centuries of substantive interactions between the Indus Valley and Persian civilizations. Diplomatic ties were formalized in 1950, and New Delhi has maintained high-level engagement with Tehran's Islamist regime after 1979. In 2003, the two countries launched a bilateral "strategic partnership" of their own, setting out to deepen economic, energy, science, and education cooperation, as well as work together on Afghan reconstruction and counterterrorism. ${ }^{150}$ Yet, as India has grown closer to the United States and other Western countries in the new century, New Delhi's policy has slowly shifted - perhaps most notably when India voted with the United States (and the majority) at key International Atomic Energy Agency sessions in 2005 and 2006-leaving most aspects of the envisaged India-Iran partnership unrealized. Most recently, New Delhi has moved to more fully embrace the international sanctions regime against Tehran, causing new tensions with Iran. In late 2010, Iran's Ayatollah Ali Khamenei made repeated mention of the "Kashmir problem," leading some to see an "anti-India tilt" in Iranian policy. ${ }^{151}$ In a reflection of more constricted bilateral commercial relations, the total value of bilateral trade dropped by more than $10 \%$ in FY2009/2010 after peaking at nearly $\$ 15$ billion the previous year. ${ }^{152}$

\footnotetext{
146 “Address by FS on 'Key Priorities in India's Foreign Policy' at the International Institute for Strategic Studies," Ministry of External Affairs transcript, June 27, 2011.

${ }^{147}$ See the external affairs minister's July 22, 2011, remarks at http://meaindia.nic.in/mystart.php?id=530217862.

148 "India, China Navies Square Off in Nearby Seas and Beyond," Reuters, September 6, 2011; Vivek Raghuvanshi, "Indian Ships Visit Vietnam," Defense News, July 11, 2011.

${ }^{149}$ See also CRS Report R40849, Iran: Regional Perspectives and U.S. Policy, coordinated by Casey L. Addis.

${ }^{150}$ See text of the January 2003 "New Delhi Declaration" at http://meaindia.nic.in/mystart.php?id=53055202.

${ }^{151}$ Pranay Sharma, “A Persian Gulf,” Outlook (Delhi), December 6, 2010.

152 "India-Iran," Ministry of External Affairs document, April 2011.
} 
There are U.S. concerns that India will seek greater energy resources from Iran, thus benefitting financially a country the United States is seeking to isolate. Indian firms have in recent years taken long-term contracts for purchase of Iranian gas and oil. Natural gas purchases could be worth many billions of dollars, but thus far differences over pricing and transport have precluded sales. Building upon growing energy ties is the proposed construction of a pipeline to deliver Iranian natural gas to India through Pakistan (the "IPI" pipeline), but participation in this project apparently has been abandoned by New Delhi. ${ }^{153}$ Still, India has imported an average of about 400,000 barrels of Iranian crude oil per day in recent years, accounting for about one-seventh of India's total oil imports and making it Iran's third-largest market in this category. ${ }^{154}$

Officially, New Delhi continues to discuss the IPI pipeline project with Tehran, along with longterm supplies of liquid natural gas (LNG), development of Iran's South Pars LNG project, the development of the Farsi oil and gas blocks, and Iran's Chabahar port and railway projects. ${ }^{155}$ Many in New Delhi see development of Iran's Chabahar port as providing India with access to Central Asian markets bypassing Pakistan. Indian officials have for years been encouraging Iran to more quickly develop the port's facilities, but Chabahar's current capacity of 2.5 million tons per year is only about one-fifth of the target. Tehran's reluctance to move faster may be linked to its concerns about security in Iran's Sistan-Baluchistan region, the site of a Sunni Muslim insurgency. Plans by India's state-owned natural gas company to purchase a $40 \%$ stake in Iran's South Pars Phase 12 gas project have been delayed by concerns about violating the international sanctions regime; banks have been unwilling to fund the investment while global pressure grows over Iran's nuclear program. ${ }^{156}$

In its new role as a nonpermanent member of the U.N. Security Council, India has firmed its stand on the need to fully implement Iran sanctions. In the final week of 2010, the Reserve Bank of India declared that a regional clearinghouse, the Asian Clearing Union, could no longer be used to settle energy trade transactions. The Obama Administration praised the decision; Washington had long sought the move as a way of making Indian companies' purchases of Iranian oil and gas more difficult, and thus of tightening sanctions targeting Iran. New Delhi may have taken the action as a means of bolstering its case for a permanent seat on the UNSC. Tehran at first refused to sell outside the previous arrangement, but quickly agreed to ensure continuing shipments as officials in both countries scrambled to find a lasting solution. By February, the two countries appeared to have found resolution by agreeing to make transactions in euros through an Iranian bank with German accounts, but, in May, proliferation-related EU scrutiny of that bank jeopardized this new arrangement and Indian payments were again halted. In early summer, Iran's state oil firm threatened Indian refiners with an August supply cutoff if the issue wasn't resolved, but Tehran quickly stated that no cutoff was planned. Still, Iranian exports were reduced, Saudi Arabia increased its sales to India to compensate, and the now estimated $\$ 4.8$ billion impasse may yet lead to a full cutoff.

\footnotetext{
${ }^{153}$ After years of denying the IPI project was in jeopardy due to New Delhi's reticence, Tehran in June 2011 conceded that the project appeared to be "stalled." Tehran has continued to encourage New Delhi's participation in the project, contending that related work on Iranian territory is $90 \%$ complete and that construction on the Pakistani side is in progress ("Iran Hopes India Will Revive IPI Project," Hindu (Chennai), June 17, 2011; "Iran Envoy Says 90 Per Cent Work on Tri-nation Gas Pipeline Complete,” BBC Monitoring South Asia, February 9, 2011).

154 “India-Iran Bilateral Relations," Ministry of External Affairs document, September 2010.

155 "India-Iran Relations," Ministry of External Affairs document, July 2011.

156 “India’s ONGC Sees Fund,” Reuters, January 12, 2011.
} 
The Iran-Libya Sanctions Act (P.L. 107-24) required the President to impose sanctions on foreign companies that make an "investment" of more than \$20 million in one year in Iran's energy sector. The $109^{\text {th }}$ Congress extended this provision in the Iran Freedom Support Act (P.L. 109293). The Comprehensive Iran Sanctions, Accountability, and Divestment Act of 2010, which became P.L. 111-195, further tightened sanctions on Iran. To date, no Indian firms have been sanctioned under these Acts, although Indian firms potentially involved in the gas pipeline project would be sanctionable, as would companies that sell gasoline to Iran. Reliance Industries of Mumbai, a major supplier in recent years, has halted such sales. ${ }^{157}$

During the period 2004-2006, the United States sanctioned Indian scientists and chemical companies for transferring to Iran WMD-related equipment and/or technology (most sanctions were chemical-related, but one scientist was alleged to have aided Iran's nuclear program). New Delhi called the moves unjustified. Included in legislation to enable U.S.-India civil nuclear cooperation (P.L. 109-401, the "Hyde Act") was a non-binding assertion that U.S. policy should "secure India's full and active participation" in U.S. efforts to prevent Iran from acquiring weapons of mass destruction. ${ }^{158}$ New Delhi firmly opposes the emergence of any new nuclear weapons powers in the region, but also opposes the use of force and even sanctions, favoring instead diplomacy to address Iran's controversial nuclear program.

The 2003 India-Iran Joint Statement included plans to "explore opportunities for cooperation in defense in agreed areas, including training and exchange of visits." ${ }^{159}$ While some in Congress have expressed concerns about signs of nascent India-Iran defense cooperation, most observers view such relations as remaining thin and patchy to date, at most, although some Indian strategic analysts call for increasing these as a means of strengthening regional security, as well as to maintain New Delhi's foreign policy independence, especially vis-à-vis the United States. ${ }^{160}$

\section{India-Russia ${ }^{161}$}

Moscow was New Delhi's main foreign benefactor for the first four decades of Indian independence. Today, Russia continues to be "a trusted and reliable strategic partner," and New Delhi views its ties with Moscow as a "key pillar of India's foreign policy."162 The Russian President was in New Delhi in December 2010 in an effort to sustain close India-Russia relations despite New Delhi's warmer relations with the West. During a follow-on visit to Moscow, External Affairs Minister Krishna described the India-Russia friendship as being a "special and privileged strategic partnership." Moscow seeks to continue supplies of nuclear technology and expertise, as well as win millions of dollars worth of contracts for the maintenance of India's extensive inventory of Russian-made military hardware. Among the outcomes of the December summit was the inking of agreements to deepen cooperation in the nuclear energy, pharmaceutical, and information technology sectors. The governments also seek to more than double annual bilateral trade to $\$ 20$ billion by 2015 (trade topped $\$ 8.5$ billion in 2010 , up 15\%

\footnotetext{
${ }^{157}$ See also CRS Report RS20871, Iran Sanctions, by Kenneth Katzman.

${ }^{158}$ In their explanatory statement accompanying P.L. 109-401, congressional conferees repeatedly emphasized their belief that securing India's assistance on this matter was "critical" (H.Rept. 109-721).

${ }^{159}$ See http://meaindia.nic.in/mystart.php?id=53055202.

${ }^{160}$ See, for example, Monika Chansoria, "India-Iran Defense Cooperation," Indian Defense Review, January 2010.

${ }^{161}$ See also CRS Report RL33407, Russian Political, Economic, and Security Issues and U.S. Interests, coordinated by Jim Nichol.

162 “India-Russia Relations,” Ministry of External Affairs document, July 2011
} 
over the previous year). ${ }^{163}$ India's single largest foreign investment is a $\$ 1$ billion stake in a joint oil and gas venture on Russia's Sakhalin Island.

Despite some post-Cold War diversification of its defense suppliers, India continues to obtain the great bulk of its imported military hardware from Russian firms, which are estimated to have been the source of more than $80 \%$ of India's total arms imports for the period 2006-2010. ${ }^{164}$ Russia's status as a main supplier of Indian defense equipment has come under threat in several disputes, including over the refitting of an aircraft carrier (which has seen major delays and cost overruns), a spat over Russia's allegedly substandard upgradation of an Indian attack submarine, and other irritants. Still, the New Delhi government appears proud to have shifted from a buyerseller defense relationship to "more elaborate and advanced cooperation" involving joint design, production, and marketing of such weapons systems as the Fifth Generation Fighter Aircraft and the Brahmos cruise missile. ${ }^{165}$

\section{India-Japan ${ }^{166}$}

India's relations with Japan only began to blossom in the current century after being significantly undermined by India's 1998 nuclear weapons tests. Today, leaders from both countries acknowledge numerous common values and interests. They are engaging a "strategic and global partnership" formally launched in 2006, when the Indian foreign minister spoke of Japan as a "natural partner in the quest to create an arc of advantage and prosperity" in Asia. He also emphasized India's desire for economic integration in Asia and cooperative efforts to secure vital sea lanes, especially in the Indian Ocean. Japan's support for the latter initiative has included plans for unprecedented joint naval exercises. New Delhi and Tokyo also share an interest in seeing membership of the U.N. Security Council expanded-both governments aspire to permanent seats.

After years of negotiations, New Delhi and Tokyo finalized a free trade agreement in October 2010, after differences over Indian tariff rates and Japanese restrictions on the importation of generic Indian pharmaceuticals were settled. Bilateral trade was already increasing rapidly: its total value in 2010 exceeded $\$ 14.5$ billion, up by some $46 \%$ over 2009 . India has also secured a $\$ 4.5$ billion loan from Japan for construction of a 900-mile freight railway between Delhi and Mumbai, the largest-ever single-project overseas loan offered by Japan. The Indian government hopes that the "Delhi-Mumbai Industrial Corridor" project will attract more than $\$ 90$ billion in foreign investment following completion. According to the Japanese Ministry of Foreign Affairs, Japan has since 1986 been India's largest aid donor. ${ }^{167}$

U.S., Indian, and Japanese naval vessels held unprecedented combined naval exercises in the Bay of Bengal in 2007 (Australian and Singaporean vessels also participated). Officials stressed that the exercises - which involved a total of 27 ships and submarines, among them two U.S. aircraft

163 "Press Conference by External Affairs Minister Shri S.M. Krishna," External Affairs Ministry transcript, January 7, 2011; "Major India, Russia Talking Points," Reuters, December 20, 2010; “India, Russia Reaffirm Strategic

Partnership," Associated Press, December 25, 2010.

${ }^{164}$ Stockholm International Peace Research Institute press release, March 14, 2011.

165 “India-Russia Relations,” Ministry of External Affairs document, July 2011.

${ }^{166}$ See also CRS Report RL33436, Japan-U.S. Relations: Issues for Congress, coordinated by Emma Chanlett-Avery.

167 “India-Japan Relations,” Ministry of External Affairs document, July 2011; “Japan-India Relations,” Japanese Ministry of Foreign Affairs document, February 2011. 
carriers - were not prompted by China's growing military strength. New Delhi favors greater trilateral India-U.S.-Japan cooperation, especially in the areas of trade and energy security, but shies from anything that could be construed as a multilateral security alliance. Washington, New Delhi, and Tokyo have plans to commence a senior-level trilateral dialogue in 2011.

\section{India-Africa}

India's historic engagement with Africa has been considerable and has included ancient trade patterns, active support for African liberation movements in the $20^{\text {th }}$ century, and robust participation in U.N. peacekeeping operations on the continent. Indian leaders appear to be reviving links to old friends in the developing world with an eye on access to natural resources and perhaps also support for a permanent seat on the U.N. Security Council. While speaking to a group of African leaders in Ethiopia in May 2011, Prime Minister Singh offered a \$5 billion line of Indian credit to nations there and pledged his government's support for African education and infrastructure. $^{168}$

India's interests and influence in Africa arguably align well with those of the United States, especially given New Delhi's commitment to secularism, pluralism, and democracy. This stands in contrast to China's role in Africa, which may be considered more mercantile. China's foreign exchange reserves of more than $\$ 3$ trillion are some ten times greater than India's, and China has been aggressive in using its state-owned development banks to make huge investments in oil, gas, and other natural resources in Africa. At \$46 billion in 2010, the value of India's total trade with the continent remains less than half of that of China. The United States may thus benefit by welcoming and coordinating with India in engagement of African countries, perhaps especially in the area of security initiatives. ${ }^{169}$

\section{India's Domestic Policy Setting}

\section{National Political System, Elections, and Parties}

India is the world's most populous democracy and remains firmly committed to representative government and rule of law. As a nation-state, India contains hundreds of different ethnic groups, religious sects, and social castes. U.S. policymakers commonly identify in the Indian political system shared core values, and this has facilitated increasingly friendly relations between the U.S. and Indian governments. In 2011, the often-cited Freedom House again rated India as "free" in the areas of political rights and civil liberties, assigning it a score identical to that of Indonesia. ${ }^{170}$

\footnotetext{
168 "India Nurturing Ties With Old, Poorer Allies," Washington Post, June 18, 2011; “India Prime Minister Pledges Billions to Africa," BBC News, May 24, 2011.

169 "India Eyes Diplomacy and Private Sector to Woo Africa," Reuters, May 27, 2011; J. Peter Pham, "India in Africa: Implications of an Emerging Power for AFRICOM and U.S. Strategy," Strategic Studies Institute, March 2011.

${ }^{170}$ Indian Kashmir, which Freedom House classifies as a "disputed territory," was rated "partly free," with some improvement in civil liberties in 2010. See http://www.freedomhouse.org/images/File/fiw/FIW_2011_Booklet.pdf.
} 


\section{National System and Elections}

With a robust and working democratic system, India is a federal republic where the bulk of executive power rests with the prime minister and his or her cabinet (the Indian president is a ceremonial chief of state with limited executive powers). Most of India's 15 prime ministers have come from the country's Hindi-speaking northern regions and all but two have been upper-caste Hindus. The 543-seat Lok Sabha (People's House) is the locus of national power, with directly elected representatives from each of the country's 28 states and 7 union territories. A smaller upper house, the Rajya Sabha (Council of States), may review, but not veto, most legislation, and has no power over the prime minister or the cabinet. National and state legislators are elected to five-year terms. The most recent parliamentary elections were held in the spring of 2009 when the incumbent Indian National Congress Party (hereinafter "Congress")-led coalition won a convincing victory, as it had five years earlier.

National elections in 1999 had secured ruling power for a Bharatiya Janata Party (BJP)-led coalition government headed by Prime Minister Atal Vajpayee. That outcome decisively ended the historic dominance of the Nehru-Gandhi-led Congress Party, which was relegated to sitting in opposition at the national level (its members continued to lead many state governments). However, a surprise Congress resurgence under party president Sonia Gandhi in the 2004 elections brought to power a new left-leaning coalition government led by former finance minister and Oxford-educated economist Manmohan Singh, a Sikh and India's first-ever nonHindu prime minister. Many analysts attributed Congress's 2004 resurgence to the resentment of rural and poverty-stricken urban voters who felt left out of the "India shining" campaign of a BJP more associated with urban, middle-class interests. Others saw in the results a rejection of the Hindu nationalism associated with the BJP.

The Congress Party and its major coalition allies significantly improved their national standing in the spring 2009 elections. More than 1,000 parties vied for office and 60\% of the country's 714 million eligible voters turned out at 838,000 polling stations. Congress Party candidates performed strongly both in direct contests against BJP opponents, as well as when contending against so-called "Third Front" candidates from a coalition of smaller regional parties that had sought to displace the incumbents. The result was a net increase of 61 Lok Sabha seats for Congress, bringing its total representation to 206 seats, or $38 \%$ of the total. Although the BJP's percentage share of the total vote was similar to that in 2004, it lost 22 more seats, and its second consecutive national defeat left it leaderless and in disarray. Meanwhile, the Left Front grouping of communist parties (former supporters of the Congress-led coalition) was devastated, losing 35 of its 60 seats. ${ }^{171}$ See Figure 1 for major party representation in the current Lok Sabha.

\footnotetext{
${ }^{171}$ The four most notable coalition allies for Congress - occupying a combined total of less than 10\% of Lok Sabha seats - are the Trinamool Congress of West Bengal, the Dravida Munnetra Kazhagam of Tamil Nadu, the Nationalist Congress Party of Maharashtra, and the Jammu \& Kashmir National Conference.
} 
Figure I. Major Party Representation in India's I th Lok Sabha

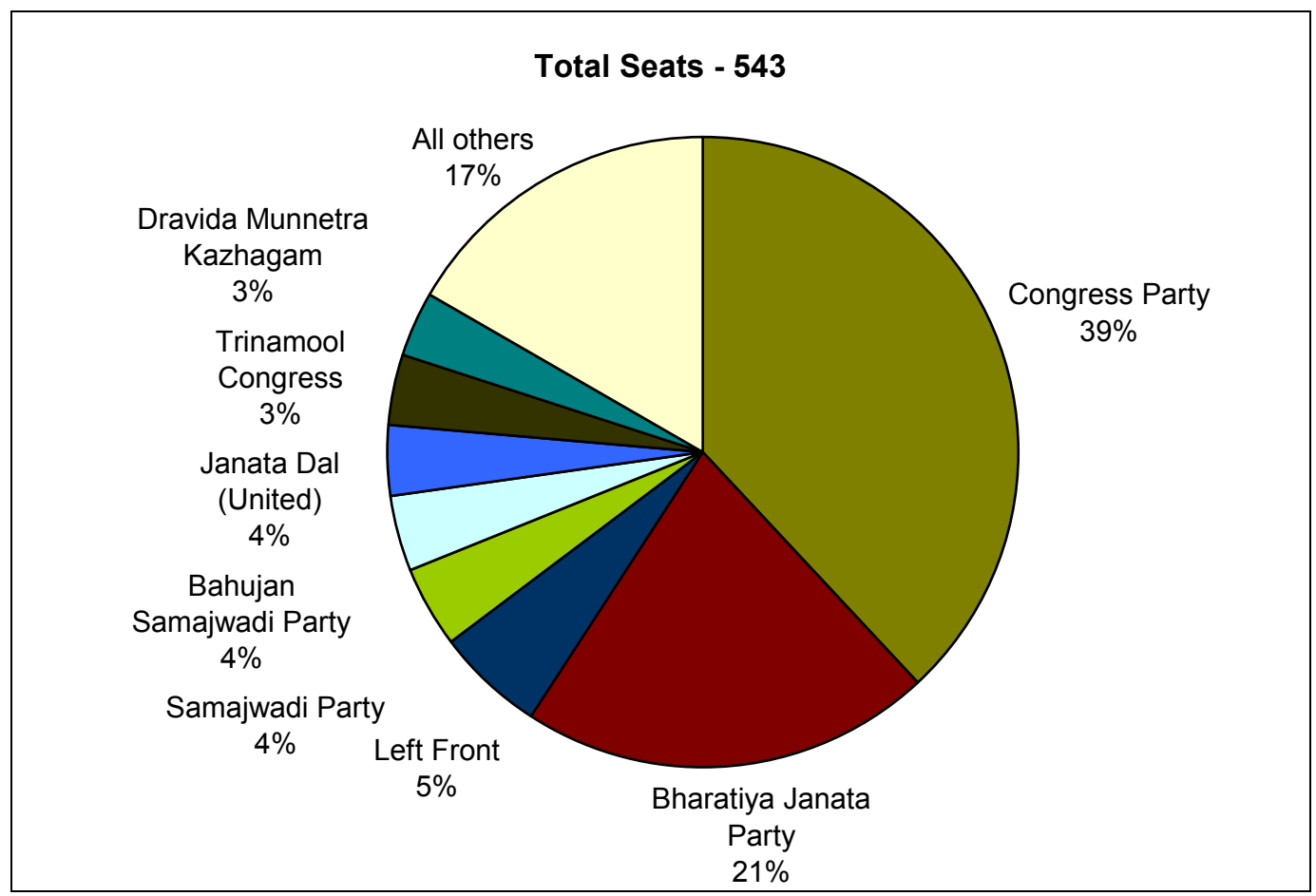

Source: Election Commission of India.

Prime Minister Singh oversees the United Progressive Alliance (UPA) ruling coalition that has now marked more than seven years in power, far exceeding the expectations of some early observers. Both he and party chief Gandhi have remained fairly popular national figures, although both have seen their favorability suffer with major corruption scandals breaking since late 2010 . Despite some notable successes, the UPA government has remained unpopular by many measures, having failed to capitalize on opportunities, and appearing to many as meek and indecisive. Singh himself, though still generally admired as an honest and intelligent figure, has been unable to succeed in pushing through much of the UPA's domestic agenda, which focuses on development and uplift for India's hundreds of millions of poor citizens.

\section{Major Political Parties}

\section{Indian National Congress ${ }^{172}$}

Congress's electoral strength had reached a nadir in 1999, when the party won only 110 Lok Sabha seats. Observers attributed the poor showing to a number of factors, including the failure of Congress to make strong pre-election alliances (as had the BJP) and perceptions that party leader Sonia Gandhi lacked the experience to lead the country. Support for the Congress, which dominated Indian politics for decades, had been in fairly steady decline following the 1984 assassination of Prime Minister Indira Gandhi and the 1991 assassination of her son, Prime Minister Rajiv Gandhi.

\footnotetext{
${ }^{172}$ See the Indian National Congress at http://www.congress.org.in.
} 
Sonia Gandhi, Rajiv's Italian-born, Catholic widow, refrained from active politics until the late 1990s. She later made efforts to revitalize the party by phasing out older leaders and attracting more women and lower castes - efforts that appear to have paid off in 2004. Today, Congress again occupies more parliamentary seats (206) than any other party and, through unprecedented alliances with powerful regional parties, it again leads India's government under the UPA coalition. As party chief and UPA chair, Gandhi is seen to wield considerable influence over the coalition's policy making process. Her foreign origins have presented an obstacle and likely were a major factor in her surprising 2004 decision to decline the prime ministership. As discussed below, her son, Rahul, is widely seen as the most likely heir to Congress leadership.

\section{Bharatiya Janata Party ${ }^{173}$}

With the rise of Hindu nationalism, the BJP rapidly increased its parliamentary strength during the 1980s. In 1993, the party's image was tarnished among some, burnished for others, by its alleged complicity in serious communal violence in Mumbai and elsewhere. Some hold elements of the BJP, as the political arm of extremist Hindu groups, responsible for the incidents (the party has advocated "Hindutva," or an India based on Hindu culture, and views this as key to nationbuilding; Hindutva can at times take an anti-Western cast). While leading a national coalition from 1998-2004, the BJP worked - with only limited success - to change its image from rightwing Hindu fundamentalist to conservative and secular, although 2002 communal rioting in Gujarat again damaged the party's credentials as a moderate organization. The BJP-led National Democratic Alliance (NDA) was overseen by party notable Prime Minister Atal Vajpayee, whose widespread personal popularity helped to keep the BJP in power.

Following its upset loss in 2004 and even sounder defeat in 2009, the party has been in some disarray. While it continues to lead several important state governments, its national influence has eroded in recent years. Party leader Lal Krishna Advani, who had served as Vajpayee's deputy and home minister while the BJP was in power, apparently sought to transcend his Hindu nationalist roots by posturing mostly as "governance, security, development" candidate in 2009; the party's loss likely ended his political career.

At present, the BJP president is Nitin Gadkari, a former Maharashtran official known for his avid support of privatization. Although still in some disorder in 2011, there are signs that the BJP has made changes necessary to be a formidable challenger in scheduled 2014 polls. These include a more effective branding of the party as one focused on development and good governance rather than emotive, Hindutva-related issues, and Gadkari's success at quelling intra-party dissidence and, by some accounts, showing superior strategizing and organizing skills as compared to his predecessors. ${ }^{174}$ Yet among the party's likely candidates for the prime ministership in future elections is Gujarat Chief Minister Narendra Modi, who has overseen impressive development successes in his state, but who is also dogged by controversy over his alleged complicity in lethal anti-Muslim rioting there in 2002 (Modi has in the past been denied a U.S. visa under an American law barring entry for foreign government officials found to be complicit in severe violations of religious freedom). ${ }^{175}$

\footnotetext{
${ }^{173}$ See the Bharatiya Janata Party at http://www.bjp.org.

174 "Race for the Crown," Times of India (Delhi), December 15, 2010.

${ }^{175}$ Despite his clear political and economic successes in Gujarat - in his ten years as Chief Minister the state has led the country on many development indicators-Modi continues to be haunted by the 2002 Ahmadabad riots, a topic he has never fully addressed in public. Although he is a safe bet to win a third term in 2012 state elections, his aspirations to (continued...)
} 


\section{Regional Parties}

The influence of regional and caste-based parties has become an increasingly important variable in Indian politics; both the 2004 and 2009 national elections saw such parties receiving about half of all votes cast. Never before 2004 had the Congress Party entered into pre-poll alliances at the national level, and numerous analysts attributed Congress's success to precisely this new tack, especially thorough arrangements with the Bihar-based Rashtriya Janata Dal and Tamil Nadu's Dravida Munnetra Kazhagam. ${ }^{176}$ The newfound power of both large and smaller regional parties, alike, is reflected in the UPA's ministerial appointments, and in the Congress-led coalition's professed attention to rural issues and to relations between state governments and New Delhi.

Two of India's three most notable regional parties are based in the densely-populated northern state of Uttar Pradesh (UP), home to some 190 million persons. The Samajwadi Party, a largely Muslim- and lower caste-based organization, is highly influential there, and holds 23 Lok Sabha seats. The rival Bahujan Samaj Party (BSP) controls the UP state government; its lower-caste, female leader and current Chief Minister Mayawati, is believed to have national political aspirations. The BSP occupies 21 Lok Sabha seats. A final regional party of note is the Janata Dal (United) (JDU), based out of neighboring Bihar and led by that state's Chief Minister, Nitish Kumar. The JDU holds 20 Lok Sabha seats.

\section{The Left Front ${ }^{177}$}

Although the Communist Party of India (Marxist) (CPI-M) seated the third largest number of parliamentarians after the 2004 elections (43), its vote bank has been almost wholly limited to West Bengal and Kerala. Communist parties (the CPI-M and several smaller allies) have in the past been bitter rivals of the Congress in these states, but a mutual commitment to secularism motivated their cooperation against the BJP in 2004. This "Left Front" is vocal in its criticisms of closer India-U.S. relations, adamantly opposing bilateral civil nuclear cooperation and railing at any signs that the United States seeks to make India a "junior partner" in efforts to counter China. This made the communists difficult partners for the first UPA government, and they subsequently were jettisoned as Congress supporters. In the 2009 national elections, the Left Front competed for 130 seats, but won only 20, suffering especially costly losses in their traditional strongholds. Many analysts attributed their setbacks to poor governance records in these very states. What may be the final blow came when 34 uninterrupted years of communist rule in West Bengal ended upon the Congress-allied Trinamool Congress Party's electoral rout of the communist coalition in May 2011 state assembly elections.

\footnotetext{
(...continued)

be the BJP's prime ministerial candidate face significant obstacles, not least the likelihood that Muslims and liberalminded Hindus would represent an anti-Modi bloc at the national level, and the BJP's key ally in Bihar, Nitish Kumar's Janata Dal (United), could be expected to abandon the alliance in protest (Geeta Anand, "Give Us Your Account, Mr. Modi” (op-ed), Wall Street Journal, February 23, 2011; Karan Shah,” Narendra Modi, Prime Minister?” (op-ed), Outlook (Delhi), April 5, 2011).

${ }^{176}$ In 2008, the DMK leader and chief minister of Tamil Nadu, home to tens of million of ethnic Tamils, threatened to withdraw his party from the Congress-led coalition - and so bring down the central government — unless India stopped "escalating" Sri Lanka's civil war, in which mostly Tamil civilians were caught in a crossfire. The threat was withdrawn days later, but the episode illuminated the fragile nature of a coalition government in New Delhi that can be destabilized by narrow regional and/or ethnic interests.

${ }^{177}$ See the Communist Party of India (Marxist) at http://www.cpim.org.
} 


\section{Corruption Scandals and Congress Party Woes}

\section{Late 2010 Corruption Stories Break}

Corruption has long been a serious problem in India (see also "India's Economy" section, below). Pervasive, major, and high-level corruption and iniquity is now identified as a central obstacle to India's economic and social development, and is seen as a key cause of a steep decline in foreign investment in late 2010 and early 2011. November 2010 witnessed a baring of two major Indian scandals that have left the national government largely paralyzed and unable to effectively govern to date. The first involves apparent corruption and gross negligence by officials overseeing the October 2010 Commonwealth Games hosted by New Delhi; the second relates to the government's sale of broadband licenses at far below market prices, costing the government many billions of dollars.

First, in November 2010, two senior Congress Party figures - the chief organizer of the Commonwealth Games and Maharashtra's Chief Minister-were forced to resign under a cloud of corruption allegations. In February 2011, two more senior Commonwealth Games officials were arrested on suspicion of corruption, specifically, for conspiring to inflate costs while procuring timers and scoring equipment from a Swiss firm at a net loss to the government of nearly \$24 million. Two months later, federal agents arrested the former chief organizer of the games on similar charges. By July, Sports Minister M.S. Gill had resigned his post.

Yet it is the telecom scandal that has been the most sensational and damaging of the several recent corruption stories, especially after an independent auditor estimated that the central government had lost some $\$ 39$ billion by selling the $2 \mathrm{G}$ spectrum rights too cheaply. Soon after the Commonwealth Games story broke came a spate of revelations about the process by which federal Communications and Information Technology Ministry officials had auctioned off parts of the $2 \mathrm{G}$ spectrum, apparently receiving only $\$ 3.6$ billion for licenses that should have been worth as much as $\$ 45$ billion. In November 2010, Communications and Information Technology Minister A. Raja, a leading Congress Party-allied DMK party figure who personally approved of the improper spectrum license sales, resigned under intense pressure and subsequently was arrested along with two other ministry officials. Police, acting upon evidence of their collusion with private sector figures, arrested a telecom company executive in February 2011. In July, another federal cabinet figure and DMK colleague of Raja's, Textile Minister Dayanidhi Maran, quit his post after coming under investigation in the scandal.

In a further embarrassment for the ruling coalition, the qualifications of a new high-level anticorruption official, P.J. Thomas, who had been appointed in September 2010, was questioned by the Supreme Court later that year due to his potentially criminal role in an alleged palm oil import scam in his home state of Kerala. By the final month of 2010, outrage from opposition parties had essentially shut down Parliament for three weeks; the Congress-led coalition was able use its majority to pass some spending bills, but most major legislation was blocked. ${ }^{178}$ The multiple scandals have continued to render the Congress-led coalition unable to push through major economic reforms that would require the acquiescence of opposition parties.

\footnotetext{
178 “Corruption Woes Mount for India's Government," Agence France Presse, November 22, 2010; “India Government is Defiant Amid Parliament Deadlock," Reuters, December 2, 2010.
} 
While it has benefitted from the UPA's woes, the main opposition BJP has not escaped culpability in recent corruption scandals. In July 2011, Karnataka's ombudsman issued a report implicating the state's BJP chief minister, B.S. Yeddyurappa, in a \$3.5 billion scandal involving the illegal mining of iron ore. Yeddyurappa, accused of receiving a \$2 million illicit payment from a mining company and selling state land at an inflated price, quickly lost the support of his party and resigned.

In addition to the major incidents of graft and corruptions discussed above, reports of large-scale political bribery sparked much outrage in early 2011 when U.S. diplomatic cables released by Wikileaks reportedly described an American diplomat's eyewitness mid-2008 account of being shown chests containing about \$25 million in cash that a Congress Party aide allegedly said was to be used as payoffs to secure Parliament's endorsement of the controversial U.S.-India civil nuclear deal. Although Prime Minster Singh himself denied that his party had paid any bribes or broken any laws, and described the account as "unverified and unverifiable," the episode has led to at least two arrests in an ongoing probe and provided further fuel for opposition party attacks on the UPA government. ${ }^{179}$ Moreover, in the current year, new attention also has focused on hundreds of billions of dollars in funds illicitly stashed by Indians abroad. In July 2011, India's Supreme Court requested that the government find and repatriate this so called "black money," adding new pressure on the Congress-led coalition to combat high-level corruption. ${ }^{180}$

While Prime Minister Singh is not accused of personal wrongdoing, he has come under fire for an allegedly inattentive management style that, for some observers, facilitated an environment in which corruption could spread. In the face of mounting pressure to act, Congress President Sonia Gandhi acknowledged that problems existed "at all levels" of society, but she squashed rumors of any rift between herself and the Prime Minister, expressing full confidence in Singh's leadership. Soon after, Singh himself offered to appear before any investigative body, declaring he had nothing to hide about his actions. Yet, as his government continued to be paralyzed by scandals and infighting into 2011, speculation about Singh's status mounted, and in February the Prime Minister gave a nationally-televised interview in which he defended his own actions, promised to crack down on corruption, and called the related scandals the greatest regret of his term in office. Days later, Singh dropped his longstanding resistance and acceded to opposition demands for a parliamentary investigation of the telecom scandal in return for an end to their filibuster that had paralyzed the legislature for two months. ${ }^{181}$

\section{Increasing Public Protest and the Rise of Anna Hazare}

By the spring of 2011, negative emotions sparked by months-long revelations of high-level corruption reached the point where mass public mobilization could occur. Two figures were notable in initiating this development: In early June, prominent yoga guru Swami Ramdev-his television program attracts about 30 million viewers - staged a major anticorruption protest in the

\footnotetext{
179 "In India, Leaked Cable About Bribes Sets Off a Furor," New York Times, March 18, 2011; "No Bribes Paid for Nuclear Deal, India Premier Says," New York Times, March 18, 2011; "India Police Widen Probe Into Cash-for-Votes Scandal," Reuters, July 21, 2011.

${ }^{180}$ A comprehensive late 2010 study determined that, from 1948 to 2008, illicit outflows totaled $\$ 213$ billion. When adjusted for accumulated interest, the value is $\$ 462$ billion (Dev Kar, "Drivers and Dynamics of Illicit Financial Flows From India: 1948-2008," Global Financial Integrity, November 2010).

181 "Indian Party's Leaders Stands By Singh," New York Times, December 19, 2010; "India Leader Offers to Testify in Scandal Inquiry," New York Times, December 20, 2010; "India's Prime Minister Vows to Fight Corruption," New York Times, February 16, 2011; "India's Parliament to Probe Telecom Scandal," Associated Press, February 22, 2011.
} 
Indian capital, and launched his own mass hunger strike to demand government action to recover "black money." That night, after apparently inaccurate reports that the government had acceded to Ramdev's demands, hundreds of police swept through the protesters, using tear gas and batons to disperse them; at least 30 people were injured. Government officials explained that Ramdev's permit allowed only for yoga and not a political demonstration; police said that permit was for a maximum of 5,000 attendees and some 40,000-60,000 showed up. Critics accused the government of using unnecessary force against peaceful protesters. ${ }^{182}$ Over following days, Ramdev's fast attracted thousands of participants across the country. Public officials were discomfited by the exercise of political influence through a perceived "publicity stunt"; other observers were alarmed that hardline Hindu nationalists were at times sharing the stage with Ramdev. There was thus relief felt across India's political spectrum when, in mid-June, Ramdev called off his fast. ${ }^{183}$

Yet a previously unknown figure has assumed far more influence at the national level. Two months before the Ramdev-led protest, social activist Anna Hazare, an uneducated 72-year-old from an indigent Maharashtran family, had set himself up at a New Delhi tourist sight and vowed to "fast unto death" unless the central government moved to toughen its anti-corruption laws, in particular by establishing a new "Lokpal" (ombudsman) post to review corruption complaints reaching to the highest levels of government. Less than a week later, after many thousands in cities across India had taken up his cause, Hazare ended his strike and declared victory upon the government's announcement that it would form a committee to draft Lokpal legislation.

The composition of that committee-five government officials and five nongovernmental activists - quickly became a matter of controversy, with critics questioning why members of civil society groups, with no standing as elected representatives of the people, should be involved in a process with major political implications. Moreover, the government representatives found themselves in serious disagreement with "Team Anna," as the civil society members and other Hazare supporters came to be known. In the end, the government officials produced one version (the Lokpal bill) and civil society members produced another (the Jan Lokpal bill). Opinion surveys have found huge majorities (80\%-90\%) of Indians favoring the civil society version.

Top Congress Party leaders, including Prime Minister Singh, have argued that multiple tactics to combat corruption are required, and that no single group could claim to represent the whole of civil society. Still, the government has come under fire for failing to open lines of communication with alternative civil society groups, leaving an impression that Hazare's movement speaks for the entire nation. Meanwhile, "Team Anna" itself has been criticized for allegedly dividing poorer minority communities, and for signs that Hindu nationalists are providing the bulk of its organizational muscle. ${ }^{184}$

\footnotetext{
182 "Supporters of Yoga Guru Assemble for an Anticorruption Protest in India," New York Times, June 4, 2011; Siddharth Varadarajan, "A Weakness Born of Bad Intent" (op-ed), Hindu (Chennai), June 6, 2011; "Hit to India's Rising Democracy?," Christian Science Monitor, June 6, 2011.

183 "Indian Gov't Skewered for Graft as Activists Fast," Associated Press, June 8, 2011.

184 "The Anna Monopoly," Telegraph (Kolkata), August 19, 2011; "Momentum for Hazare's Anticorruption Movement Draws Out Opposition," Christian Science Monitor, August 22, 2011; "India Graft Buster Has His Critics," Agence France Presse, August 21, 2011.
} 


\section{Status of the "Lokpal" Legislation}

On July 28, 2011, 43 years after the first draft was conceived, India's federal cabinet approved a Lokpal bill that did not include serving prime ministers or the higher judiciary under its purview. ${ }^{185}$ The bill did, however, incorporate some minor provisions of the Jan Lokpal bill and had the support of all but one of the Congress Party's coalition partners. Nevertheless, Hazare called the bill "unacceptable," and the opposition BJP joined him in expressing disappointment that the prime minister was excluded from oversight.

To express his dissatisfaction with the government's actions, Hazare vowed to begin another fast "unto death" in New Delhi on August 16. On that morning, as thousands of supporters began to gather at a city park, plain-clothes police arrested Hazare and took him away. At this point, his supporters released a pre-recorded videotape in which Hazare, anticipating his own detention, announced the start of a "second independence campaign" for India. By jailing Hazare, the government looked both inept and undemocratic, and united a wide range of otherwise reluctant actors in support of Hazare's movement. In a further twist, Hazare refused an offer to be released until he was given permission to launch a 15-day hunger strike without any restrictions on crowd size at the anticipated protest site. ${ }^{186}$

In late August, a parliamentary committee began considering the Jan Lokpal bill submitted by Hazare and his supporters, thus meeting a central demand of the protestors. Yet Hazare rejected a personal plea from the prime minister to end his fast until being guaranteed that certain key provisions of the bill would be enacted. On August 27, the $13^{\text {th }}$ day of his latest fast, Hazare declared victory when negotiations among government ministers, opposition lawmakers, and civil society representatives resulted in an agreement. ${ }^{187}$

\section{Congress Party Woes}

Even before major corruption scandals broke in late 2010, the Congress-led UPA was under considerable criticism for drift and ineffectiveness. Since that time, the decline of the Congress Party's standing has been precipitous: less than two years after the party won a convincing 2009 national reelection victory, opinion polls showed a majority of Indians believing the UPA coalition had lost its moral authority to rule. Many analysts identify the slow response to corruption scandals as having been particularly damaging. ${ }^{188}$

In the face of growing public anger, Prime Minister Singh made changes to the federal cabinet in January, demoting several ministers who had been tainted by scandal or criticized for ineffectiveness. Yet the changes were relatively minor, leaving most commentators unimpressed, and the opposition BJP accused the government of lacking enough courage to remove corrupt

\footnotetext{
${ }^{185}$ The approved Lokpal would be chaired by a former Supreme Court justice and comprised of eight other members, at least half of whom must also be former Supreme Court justices. It could investigate prime ministers who have left office, sitting or former federal ministers, members of Parliament, "Group A" civil servants and above, and the chairperson and senior executives of any company or body that is at least partly financed or controlled by the government. Only a Chief Justice could investigate allegations of corruption against Lokpal members.

186 "Jail the Messenger," Economist (London), August 16, 2011; “Indian Anticorruption Leader to Leave Jail," New York Times, August 18, 2011.

187 “In India, Anti-Graft Activist Declares Victory,” Los Angeles Times, August 28, 2011.

${ }^{188}$ Vidya Subramaniam, “A Year of Down and Down for Congress" (op-ed), Hindu (Chennai), December 31, 2010; "The Decline and Stall of the Congress Empire," India Today (Delhi), July 11, 2011.
} 
figures. ${ }^{189}$ Over the course of recent political upheaval, Singh's mild, nonpolitical bearing, once considered part of his appeal, has for many become a liability, especially as the Indian leader has appeared slow-footed in reacting to national outrage over increasing evidence of high-level corruption. In June, he publically denied charges that he had become a "lame duck" leader. ${ }^{190}$

Poor economic news also continues to leech support for the Congress-led government; in February, some 100,000 trade unionists took to the streets of New Delhi to protest high food prices and unemployment. In March, the Congress Party nearly lost one of its key coalition partners, Tamil Nadu's Dravida Munnetra Kazhagam (DMK), which has 18 seats in Parliament but was badly beaten in state elections. Some Congress leaders reportedly wanted to end ties with the DMK, given that the federal minister at the center of the ongoing telecom scandal, A. Raja, was a DMK figure who was seen to taint the overall coalition. In the end, however, Congress president Sonia Gandhi chose to maintain a DMK role in the UPA coalition upon condition that it concede to Congress's demand for more Tamil Nadu state assembly seats. ${ }^{191}$

Meanwhile, Congress President Gandhi is suffering from an unknown illness, and in early August virtually disappeared from India's political stage, having left the country for surgery at an undisclosed U.S. hospital. Moreover, as key Congress figures express support for the future leadership role of Sonia Gandhi's youthful son, parliamentarian Rahul Gandhi, Manmohan Singh's political authority is correspondingly undermined. The 2009 polls may have represented a coming out party of sorts for the younger Gandhi, who many expect to be put forward as Congress's prime ministerial candidate in scheduled 2014 elections. Yet this heir-apparent remains dogged by questions about his abilities to lead the party, given a mixed record as an election strategist, uneasy style in public appearances, and reputation for gaffes. ${ }^{192}$

\section{Notable State-Level Developments}

Perhaps India's best example of effective governance and impressive development is found in Gujarat (pop. 60 million), where controversial Chief Minister Narendra Modi has streamlined economic processes, removing red tape and curtailing corruption in ways that have made the state a key driver of national economic growth. Seeking to overcome the taint of his alleged complicity in deadly 2002 anti-Muslim riots, Modi has overseen heavy investment in modern roads and power infrastructure, and annual growth of more than $11 \%$ in recent years. The state has attracted major international investors such as General Motors and Mitsubishi and, with only 5\% of the country's population, Gujarat now accounts for more than one-fifth of India's exports. ${ }^{193}$

Another positive example in 2011 has been Bihar (pop. 104 million), one of India's poorest states, where Chief Minister Nitish Kumar has won national attention through his considerable success in emphasizing good governance over caste-based politics; he is credited with restoring law and order across much of the state, as well as overseeing infrastructure and educational

\footnotetext{
189 “India’s Prime Minister Shuffles Cabinet,” New York Times, January 19, 2011.

190 "Will Singh's Understatement Become His Undoing?,” Time, January 26, 2011; Sadanand Dhume, "Corruption on Singh's Watch" (op-ed), Wall Street Journal, March 22, 2011; "India PM Manmohan Singh Denies 'Lame Duck' Charge," BBC News, June 29, 2011.

191 “Congress' Tough Talking With DMK Yields Results,” Hindu (Chennai), March 10, 2011.

192 "Rahul Gandhi: A Leader in Waiting for World's Largest Democracy,” Reuters, June 29, 2011.

193 “A Glimpse at India, Minus the Red Tape,” Wall Street Journal, January 14, 2011.
} 
improvements of direct benefit to common citizens projects. ${ }^{194}$ Kumar's Janata Dal (United) party, in alliance with the main national opposition BJP, won an overwhelming reelection majority in November 2010 state elections.

The examples set in by Chief Ministers Modi and Kumar may have inspired the popular leader of India's most populous state, Uttar Pradesh (pop. 200 million). Chief Minister Mayawati, who is widely believed to maintain national political ambitions and was at the forefront of a nascent "Third Front" in 2009, has shifted her own focus much more toward infrastructure projects such as road-building and improving the state's poor energy grid. ${ }^{195}$

An ongoing movement to carve a new state out of Andhra Pradesh (pop. 85 million) has caused sometimes major public disturbances. The UPA government had first committed to form the new state in late 2009, but has since deferred, causing protests. Because the new state would include the important high-technology hub of Hyderabad, the movement could have both domestic and international economic implications. In March 2011, 100,000 proponents of a new Telangana state were detained by police and another 50,000 rallied in defiance of an unofficial curfew. In July, a statewide protest strike disrupted business and transportation, and nine Congress party Lok Sabha members resigned over their party's failure to take a stand on the issue. ${ }^{196}$

In the key eastern state of West Bengal (pop. 91 million), the group of communist parties that had ruled the state for 24 years met with an historic reversal in 2011 state elections, falling from 235 assembly seats to only 61 . The big winner was the Trinamool Congress of Mamata Banerjee, a federal cabinet minister in the Congress-led national coalition (her party had in the past allied with the BJP). As West Bengal's new Chief Minister, Banerjee is faced with repairing one of India's poorest states.

In Tamil Nadu (pop. 72 million), the Dravida Munnetra Kazhagam (DMK), a major Congress Party ally in the national coalition, was routed and lost power in June state assembly elections, winning only 30 seats after having won 160. Their rivals, sometime BJP allies All India Anna Dravida Munnetra Kazhagam (AIADMK), now enjoy an overwhelming majority in that state.

Finally, Jammu and Kashmir (pop. 13 million) held local Panchayat (village-level) elections from April to June, described by the state's chief minister as the first "real" such poll in 33 years (the 2006 round was deferred due to security circumstances and the 2001 round was not considered credible by most observers). More than five million voters representing more than three-quarters of the electorate cast votes in the largely peaceful election. New Delhi urges the state government to move quickly on a devolution plan that would transfer more power to the more than 4,000 newly elected village leaders. ${ }^{197}$

\footnotetext{
194 “Turning Around an Indian State," New York Times, November 23, 2010.

195 "Highway in India Offers New Solution to Land Fights," New York Times, February 22, 2011.

196 “India: Arrests Before Telangana ‘Million-Man’ Rally,” BBC News, March 10, 2011; Strike Grips India State, Piles Pressure on Government," Agence France Presse, July 5, 2011.

${ }^{197}$ Ajit Kumar Singh, "Democracy and Its Discontents,” Outlook (Delhi), July 4, 2011.
} 


\section{India's Economy}

\section{Overview}

India has been in the midst of a major and rapid economic expansion, with an economy projected to soon be the world's third largest. Although there is widespread and serious poverty in the country, observers believe long-term economic potential is tremendous, and recent strides in the technology sector have brought international attention to such new global high-technology centers as Bangalore and Hyderabad. However, many analysts and business leaders, along with U.S. government officials, point to excessive regulatory and bureaucratic structures as a hindrance to the realization of India's full economic potential. ${ }^{198}$ Although India has made major progress in reducing corruption, it is still perceived as a major obstacle for the economy. ${ }^{199}$ The high cost of capital (rooted in large government budget deficits) and an abysmal infrastructure also draw negative appraisals as obstacles to growth. ${ }^{200}$ Ubiquitous comparisons with the progress of the Chinese economy show India lagging in rates of growth, foreign investment, poverty reduction, and in the removal of trade barriers. ${ }^{201}$

It is a testament to the strength of India's economy that, even in the face of widespread corruption, poor infrastructure, political uncertainty, inflationary pressures, and more recently, declining rates of foreign investment, it has continued to grow by at least $8 \%$ annually in recent years. In the absence of such major obstacles, the national economy would most likely enjoy double-digit growth, and in many respects government is seen to be an impediment rather than facilitator of better performance. ${ }^{202}$

According to the International Monetary Fund (IMF), India's nominal gross domestic product (GDP) in 2010 was $\$ 1.538$ trillion, making it the $9^{\text {th }}$ largest economy in the world. However, with a population of 1.17 billion people, India's per capita GDP is $\$ 1,265,139^{\text {th }}$ in the world and slightly higher than that of Pakistan, but still below that of Bhutan. Although India has had one of the fastest growing economies in the world since 2001, relatively high income disparities have left much of India's population in poverty. According to the United Nations Development Program (UNDP), nearly a third of India's population, and more than $60 \%$ of its women, live below the national poverty line. ${ }^{203}$

\footnotetext{
${ }^{198}$ In 2006, the U.S.-India CEO Forum - composed of ten chief executives from each country representing a crosssection of key industrial sectors - issued a report identifying India's poor infrastructure and dense bureaucracy as key impediments to increased bilateral trade and investment relations (see "U.S.-India Strategic Economic Partnership," U.S.-India CEO Forum, March 2006 at http://planningcommission.nic.in/reports/genrep/USIndia.pdf).

${ }^{199}$ Berlin-based Transparency International placed India $87^{\text {th }}$ out of 178 countries in its 2010 "corruption perceptions index," characterizing it as moderately corrupt, with a score of 3.3, comparable to China, Greece, and Thailand. India also appears in the lowest cluster of the group's 2008 "bribe payer's index."

${ }^{200}$ Most recently, India's infrastructural challenges were made apparent when preparations for October's Commonwealth Games in Delhi were marred by numerous problems, including unsanitary venues and a bridge collapse ("The Con Games," India Today (Delhi), August 2, 2010; "Games Fiasco Highlights Fissures in Indian Government," Reuters, September 23, 2010).

${ }^{201}$ India's traditional "it'll do" (chalta hai) attitude, a form of satisficing, is seen to underlie many of its infrastructural and bureaucratic problems, potentially hindering the country's growth as a global power ("As Games Close, India Ponders a Deep-Seated 'It'll Do' Attitude," Los Angeles Times, October 15, 2010).

202 "Why India Can't Grow at 10 Per Cent,” India Today (Delhi), February 28, 2011; “In India, Dynamism Wrestles With Dysfunction," New York Times, June 8, 2011.

${ }^{203}$ See http://www.undp.org.in/whatwedo/poverty_reduction.
} 
India was struck by the secondary effects of the global financial crisis of 2008, but its impact was comparatively light. According to the IMF, real GDP growth decreased from $7.3 \%$ in 2008 to $5.7 \%$ in 2009 . While its financial sectors were largely insulated from the collapse of selected financial markets, the ensuing economic slowdown (particularly in Europe and the United States) led to a drop in demand for India's leading exports. In addition, the decline in global liquidity placed downward pressure on India's currency, the rupee. With less access to overseas capital, India's private sector turned to domestic sources, leading to a rise in interest rates. To expedite India's recovery, the Indian government passed a fiscal stimulus package amounting to about 3\% of GDP in December 2008.

Consultations have begun for the India's $12^{\text {th }}$ five-year plan. Deputy Chairman of India's Planning Commission Montek Ahluwalia wrote a May 2011 article summarizing India's performance during the $11^{\text {th }}$ five-year plan and setting out four major challenges for the $12^{\text {th }}$ five-year plan. According to Ahluwalia, India had done well in achieving the growth targets of the latest plan, but was less successful in efforts to reduce poverty. Although overall poverty rates were lowered, India continues to struggle with significant income and wealth inequality across regions, and between the urban and rural population. Looking ahead to the $12^{\text {th }}$ five-year plan, Ahluwalia sees four major challenges: (1) managing the energy sector; (2) managing the water resources; (3) addressing the problems associated with the expected urbanization; and (4) protecting the environment during rapid economic growth. He also highlights ongoing issues for India that include provision of basic services to the poor, access to education (particularly in rural areas), and the rise of "crony capitalism," wherein government officials and major corporations selfishly manipulate markets and government procurement to the detriment of India. ${ }^{204}$

India's economy is showing signs of rebounding from the 2009 slowdown. Real GDP growth in FY2010 was 7.4\% and in FY2011 was 8.5\%. India's Planning Commission has set a goal of 10\% annual growth for the nation's $12^{\text {th }}$ Five-Year Plan (2012-2017). However, the nation faces several major obstacles to further economic development, including endemic and stubborn poverty; poor infrastructure; corruption and market economy restrictions; inflationary pressures; fluctuating rates of foreign investment; and other issues.

\section{Poverty}

Despite impressive economic growth, India continues to fare poorly in human development measures; the U.N.'s 2010 Human Development Index ranked India $119^{\text {th }}$ among 169 countries, but lowered India's composite score by some $30 \%$ over the previous year, in large part due to increasing inequalities. A "Multidimensional Poverty Index" created by the University of Oxford found in 2010 that more than half of the world's poor people live in South Asia, and that 645 million - more than half of all Indian citizens - are "poor" by their measure. ${ }^{205}$ Critics of neoliberal economic policies say the growth resulting since post-1991 reforms has been uneven, favoring only a fraction of the population, especially those in the services sector, while harming

\footnotetext{
${ }^{204}$ Montek Ahluwalia, "Prospects and Policy Challenges in the Twelfth Plan," Economic \& Political Weekly (Mumbai), May 21, 2011.

${ }^{205}$ Eight Indian states alone (Bihar, Chhattisgarh, Jharkhand, Madhya Pradesh, Orissa, Rajasthan, Uttar Pradesh, and West Bengal) are home to 421 million people living in poverty, more than the combined total of Africa's 26 poorest countries (see the Index at http://www.ophi.org.uk/policy/multidimensional-poverty-index).
} 
the vital agriculture sector and doing little to alleviate poverty, which continues to affect at least one-third of the population. ${ }^{206}$

The benefits of India's recent economic growth has also been geographically mixed. Less attention is given to the fact that India's impressive economic boom has not been country-wide. Some states - especially Maharashtra, Gujarat, Karnataka, Tamil Nadu, and Delhi-have enjoyed rapid growth, while others - most notably densely-populated Uttar Pradesh — continue to struggle with underdevelopment. Such uneven performance becomes stark when malnourishment rates are considered: the average caloric intake among India's poorest states has remained static for more than a decade, and more than half of India's children under the age of five suffer developmental problems due to inadequate nutrition. Some analysts contend that static rates of malnutrition among India's children are evidence that economic growth there is benefiting only narrow sections of the society. Young females remain particularly vulnerable to malnutrition. ${ }^{207}$

Decades of central government social uplift schemes have a poor record of success to date. Massive government spending on poverty-reduction programs have met with halting progress, at best, most likely because of corruption and poor administration. Despite spending about $2 \%$ of its GDP on such programs in 2010 - a higher percentage than any country in Asia and some three times that spent by China - food, health, and job insecurity persist. ${ }^{208}$

\section{Poor Infrastructure}

India's infrastructure is inadequate and inefficient. Analysts continue to identify this poor infrastructure as perhaps the most serious impediment to greater economic development, and they urge political reforms at the state level so as to better deliver reliable energy and transportation services. Indian officials report that only $20 \%$ of India's urban sewage is treated before disposal and less than $25 \%$ of its 85 largest cities have local bus service. According to a U.S. State Department official, India will need to invest $\$ 1.25$ trillion in energy production, $\$ 392$ billion in transportation infrastructure, and $\$ 143$ billion in health care by 2030 to support its rapidly growing population. ${ }^{209}$ Poor infrastructure costs India an estimated $2 \%$ in annual economic growth. Urban areas are especially affected, with the pace of urban development outstripping that of population increases; the country spends only $\$ 17$ per capita on urban infrastructure as compared with $\$ 116$ per capita in China. ${ }^{210}$ A World Bank study estimated that a lack of toilets and poor public hygiene cost India some $\$ 54$ billion each year though premature deaths, treatment for the sick, and lost tourism revenue. ${ }^{211}$

\footnotetext{
${ }^{206}$ See, for example, Praful Bidwai, "Shining \& Starving" (op-ed), Frontline (Chennai), August 13, 2011.

207 "High Growth Fails to Feed India's Hungry," Financial Times (London), December 22, 2010; "India: Despite Growth, Struggle Continues With Malnutrition Among Children," New York Times, March 7, 2011; "Despite Economic Growth, India Lets Its Girls Die," Associated Press, May 4, 2011.

208 "Spent Farce," India Today (Delhi), August 30, 2010; "India's Anti-Poverty Programs Are Big But Troubled,” New York Times, May 18, 2011.

${ }^{209}$ Jessica Seddon, "India’s Catastrophic Landscape.” Harvard International Review, March 7, 2011; "India Unprepared for Urban Boom," Washington Post, July 11, 2011; Geoffrey Pyatt, "The Importance of U.S.-India Business and Economic Relations," State Department transcript, June 24, 2011.

210 "India's Cities Grow Fast Develop Slowly," Reuters, August 3, 2010.

${ }^{211}$ World Bank, "The Economic Impacts of Inadequate Sanitation in India," 2010.
} 
India's system for generating and distributing electricity poses a particular problem for the nation's economic growth, as undercapacity and poor management lead to frequent brownouts and blackouts. In addition, many businesses and households illegally tap into the electrical grid for power. Efforts to reform India's electricity system have been repeatedly thwarted by local politicians, who use access to electricity as a means of staying in power. India's transportation infrastructure is also in need of greater investment. The Indian government has been making significant investments in the nation's roads, but much still needs to be done.

\section{Corruption and Economic Freedoms}

Berlin-based Transparency International placed India $87^{\text {th }}$ out of 178 countries in its 2010 "corruption perceptions index," characterizing it as moderately corrupt, with a score of 3.3, comparable to China, Greece, and Thailand. India also appears in the lowest cluster of the group's 2008 "bribe payer's index." 212 Evidence of rampant, high-level corruption is another contributor to a downturn in India's economic outlook, leading to what one parliamentarian and former businessman called a "psychological crisis of confidence" for the country. By some accounts, graft now rivals poor infrastructure as the most acute concern of foreign investors. ${ }^{213}$

The Heritage Foundation's 2011 Index of Economic Freedom - which may overemphasize the value of absolute growth and downplay broader quality-of-life measurements — rated India's economy as being " $55 \%$ free" and ranked it $124^{\text {th }}$ out of 179 countries. The index highlights restrictive trade policies, heavy government involvement in the banking and finance sectors, rigorous investment caps, demanding regulatory structures, and a high incidence of corruption. The Vancouver-based Fraser Institute provides a more positive assessment, while also faulting India's excessive restrictions on capital markets. ${ }^{214}$

\section{Inflationary Pressures}

Inflationary pressures in India remain strong, particularly for food, which has a disproportionally harmful effect on the poor. India's wholesale price index for July 2011 was up $9.44 \%$ compared to a year before. ${ }^{215}$ The Reserve Bank of India (RBI) raised interest rates in June 2011 - the $10^{\text {th }}$ such interest rate increase in 16 months - in an effort to reduce inflation. The RBI reportedly attributes some of India's inflation problems to the ongoing government debt crisis in Europe. Prime Minister Singh has called inflation a "serious threat" to future economic growth, saying that rates above $8 \%$ are unsustainable. Food inflation has been a particular concern, with prices rising at annual rates of up to $18 \%$ in late 2010 and early 2011. Rising food and crude oil prices have evoked fears among some that India's high rates of inflation may be structural rather than cyclical, given a national economy characterized by supply constraints, shortages of skilled labor, and quickly rising expectations among the populace. ${ }^{216}$

\footnotetext{
${ }^{212}$ See http://www.transparency.org. According to Transparency's findings, one in three Indian families living below the poverty line paid a bribe in 2007 for basic public services.

${ }^{213}$ Quoted in “India's Mood Darkens As Corruption Undermines Nation's Self-Confidence," Washington Post, March 9, 2011; “A Rotten State,” Economist (London), March 10, 2011.

${ }^{214}$ See http://www.heritage.org/research/features/index/country.cfm?id=India and http://www.fraserinstitute.ca/admin/ books/chapterfiles/3aEFW2006ch3A-K.pdf\#.

215 “June Inflation Jumps 9.44\%, May Trigger Rate Hike,” Economic Times (Mumbai), July 16, 2011.

216 “India's Economic Growth Under 'Threat' From Inflation,” BBC News, February 4, 2011; “Inflation Pressure (continued...)
} 


\section{Foreign Investment}

India has become an increasingly lucrative investment destination for international finance in recent years. Yet FDI into India dropped by nearly one-third over the entire course of 2010, and the country's Nifty 50 stock index was down $17 \%$ in the first month of 2011 , falling from record highs only two months earlier. Along with infamous bureaucratic hurdles to investment, foreign investors are more recently seen to be deterred by India's corruption scandals and high rates of inflation. Despite such hiccups, FDI levels were on the rise again by mid-2011. FDI dropped by $25 \%$ in the fiscal year ending March 2011, but shot up by $300 \%$ for the month of June $2011 .^{217}$ Also in June, the central government halted efforts to secure land for what would be the country's largest-ever foreign investment project, a long-delayed $\$ 12$ billion steel plant to be built by a South Korean interest. Although the project received final go-ahead in May after a five-year delay, protesting farmers' families have blocked the selected site, halting work "indefinitely." 218 The tensions between the government's central aim of further economic development is persistently at odds with the country's still relatively closed and restrictive economy.

\section{Other Economic Issues}

Employment, monetary policy, and bureaucratic "red tape" are further problem areas for New Delhi's economic decision makers. India continues to be bedeviled by unemployment and underemployment. Despite years of comparatively high economic growth, job creation has lagged well behind the increases in international trade and GDP. In contrast to neighboring China, India's economic growth has relied on more capital-intensive, low employment sectors (such as information technology) and less on labor-intensive manufacturing. In addition, for much of rural India, there are few employment alternatives to agriculture.

Moreover, India's monetary policy is under pressure from differing directions. After nearly two decades of economic reform, India's financial sector remains a mixture of state and private institutions subject to selective strict regulatory control. India's central bank and chief regulator of the nation's financial system is the Reserve Bank of India (RBI). The Indian government and the RBI have generally maintained a relatively conservative view on financial regulation, prohibiting institutions from taking on excessive risk or allowing overexposure to international capital flows. This has been reinforced by the Asian financial crisis of 1997, as well as the global financial crisis of 2008. To sustain economic growth, the RBI could lower interest rates, but its concerns about inflation would support raising interest rates. In addition, India's comparatively high interest rates (India's commercial banks' prime lending rates are between $11 \%$ and $14 \%$ ) have contributed to inward capital flows and a strengthening of the rupee. However, under India's "managed float" exchange rate regime, the RBI has attempted to reduce upward pressure on the rupee to maintain the competitiveness of India's exports. As of September 2011, U.S. $\$ 1=45.85$ rupees.

\footnotetext{
(...continued)

Mounts on New Delhi," Financial Times (London), June 22, 2011.

217 "India Becomes Destination of Choice for World's Investors," New York Times, October 13, 2010; "Foreign Investment Ebbs in India, and Questions Begin," New York Times, February 24, 2011; "India's Foreign Direct Investment Picks Up,” Wall Street Journal, July 4, 2011.

218 “India Suspends Land Acquisitions for POSCO Steel Plant,” Washington Post, June 21, 2011.
} 
Finally, although the days of the infamous "License Raj" are gone, India continues to have a very complex bureaucratic system, often involving multiple layers of government and numerous agencies with regulatory oversight of the economy. ${ }^{219}$

\section{India's Energy, Environment, and Climate Change Policies}

\section{Energy Issues}

India's continued economic growth and security are intimately linked to the supply of energy resources. Indeed, Indian leaders insist that energy security is an essential component of the country's development agenda, calling for an integrated national energy policy, diversification of energy supplies, greater energy efficiency, and rationalization of pricing mechanisms. The country's relatively poor natural energy resource endowment and poorly functioning energy market are widely viewed as major constraints on continued economic growth. The current New Delhi government aspires to increase the nation's electricity generation by five-fold by the year 2030. The U.S. government has committed to assist India in promoting the development of stable and efficient energy markets there; a U.S.-India Energy Dialogue was launched in 2005 to provide a forum for bolstering bilateral energy cooperation. ${ }^{220}$

India was the world's fourth largest energy consumer in 2009 (after the United States, China, and Japan) and may become third by the middle of this century. Overall power generation in the country more than doubled from 1991 to 2005, and the country's energy demands are expected to quadruple by 2035 . Estimates suggest that in order to maintain current rates of economic growth India will need to expand energy consumption by approximately $4 \%$ per year while reducing energy intensity. ${ }^{221}$ As of March 2011, India's total installed power generation capacity mix was $54 \%$ coal, $22 \%$ hydro, $11 \%$ renewables (including biomass, waste, wind, and solar), $10 \%$ gas, and $3 \%$ nuclear. $^{222}$

India is the world's third most productive coal producer (although most of India's coal is an inefficient low-grade, high-ash variety), but also the world's fourth-ranked importer. New Delhi is beginning to develop coalbed methane despite concerns about carbon emissions and the impact on limited water resources. About $70 \%$ of India's oil is imported (at a rate of 2.1 million barrels per day in 2009), mostly from the West Asia/Middle East region, making India a leading net importer in this category, as well. India's domestic natural gas supply, while significant, has not keep pace with demand, and the country has been a net importer since 2004. Hydropower, especially abundant in the country's northeast and near the border with Nepal, is a booming sector. Nuclear power, which Indian government officials and some experts say is a sector in dire need of expansion, continues to account for less than $3 \%$ of total electricity generation. ${ }^{223}$

\footnotetext{
219 The License Raj refers to the complex regulations and licenses required to establish a business in India before the implementation of economic reforms in 1990. However, many observers still see India's economy as overregulated.

${ }^{220}$ See U.S. Department of Energy information at http://www.pi.energy.gov/usa_india_energy_cooperation.htm.

221 "Power Challenge," Business Day (Bangkok), June 7, 2011.

${ }^{222}$ See Indian Ministry of Power data at http://powermin.nic.in.

${ }^{223}$ Energy data, mainly from 2007-2009, from U.S. Department of Energy, Energy Information Administration, August 2010, at http://www.eia.doe.gov/emeu/cabs/India/Profile.html; and the International Energy Agency's October 2010

"Key World Energy Statistics" at http://www.iea.org/textbase/nppdf/free/2010/key_stats_2010.pdf.
} 
Roughly one-fifth of the India's power is consumed by farmers' irrigation systems, making the farm lobby a powerful obstacle to curtailing subsidies provided by State Electricity Boards, which collectively lose billions of dollars annually. Moreover, from one-quarter to one-half of India's electricity is said to disappear though "transmission losses," i.e., theft. Approximately $44 \%$ of rural households, representing some 400 million Indians, do not have access to electricity. Government plans to increase energy production by $65 \%$ in less than a decade will increase demand for coal-fired power plants by an estimated $2 \%$ per annum to nearly double by $2030 .^{224}$

India's dependence on oil imports presents India with a strategic and economic vulnerability and acts as an impetus for developing alternative sources of energy and reducing demand. In the absence of alternative energy sources, India's net oil imports are projected to increase to $90 \%$ by $2030 .^{225}$ New Delhi's $11^{\text {th }}$ five-year plan includes a target of increasing energy efficiency by $20 \%$ by the year $2017 .{ }^{226}$ New Delhi has set a goal of $20 \%$ of its energy coming from renewable sources by 2020 and having $15 \%$ of its greenhouse gasses taken up by its forests by 2030 . India hopes to create a new carbon sink by expanding forest cover from $22 \%$ of total land area to $33 \%$ of its land area. A shift to relatively cleaner oil or gas will likely necessitate further dependence on foreign sources of energy, most from the Middle East. It is likely that the Government of India will continue developing alternative energy sources, such as solar, because there is a perception that India's growth will be jeopardized unless it embraces alternative sources of energy. The country's Solar Mission's Plan may face major challenges in its goal of increasing solar energy production to 20 gigawatts by $2020 .^{227}$ The extent to which it will be successful in this objective and the time frame within which it may do so remain obscure. A market-based mechanism known as the Perform, Achieve, and Trade (PAT) scheme was initiated in 2011 to set benchmark efficiency standards for 563 power plants, steel mills, and cement plants that collectively account for more than half of India's energy consumption. The scheme includes energy savings certificates that can be sold and traded. ${ }^{228}$

\section{The Environment and Climate Change Issues}

The carrying capacity of India's land is under stress. India has $2 \%$ of the world's surface area, $4 \%$ of the its fresh water, and $17 \%$ of its population. Over $70 \%$ of Indians depend on farm incomes with about $65 \%$ of Indian farms dependant on rain fall. Pressure on agricultural production from climate change is exacerbated by degraded soils and water shortages. An estimated $45 \%$ of Indian land is seriously degraded due to erosion, soil acidity, alkalinity and salinity, and water logging.

\footnotetext{
${ }^{224}$ Caroline Friedman and Terasita Schaffer, "India's Energy Options: Coal and Beyond," South Asia Monitor, August 24, 2009.

${ }^{225}$ India's need for imported oil has become voracious in the past decade, with the bill reportedly increasing six-fold to more than $\$ 85$ billion in FY2009/2010. Although New Delhi launched its now energetic search for access to oil and gas assets later than did China, and does not enjoy Beijing's deeper pockets, its oil conglomerates invested some $\$ 12$ billion in acquiring overseas assets in the last fiscal year ("India Hunts for Oil," India Today (Delhi), October 10, 2010).

226 “India's Per Capita Carbon Emissions to Rise Threefold by 2030,” Business News, February 25, 2010.

${ }^{227}$ Shyam Saran, Special Envoy of the Prime Minister for Climate Change, "India's Climate Change Initiatives," Address to The Carnegie Endowment for International Peace, March 24, 2010, Washington, DC.

228 "Teething Problems Shadow India Solar Power Dreams," Reuters, May 23, 2011; "India Takes Unique Path to Lower Carbon Emissions," Reuters, May 29, 2011.
} 
Rain has become more erratic in recent years as ground water is being depleted. One study found that the water table in India's northwest is falling by 1.6 inches per year. ${ }^{22}$

Global climate change is anticipated to affect India in a number of ways. Sea level rise from global warming would inundate low lying areas. More intense and destructive weather events, such as cyclones, are also anticipated. Potential changes to the monsoon rains, which are critical for agricultural production in India, could also reduce agricultural output and undermine food security for millions in India. Rising temperatures will also likely lead to Himalayan glacial melt that would alter the flow of India's rivers. The Indian Institute for Meteorology has demonstrated that global warming will likely cause erratic monsoon behavior in India that would itself lead to static or declining food output for India. Agricultural yield in India grew over 3\% for the 1980s. This has already slowed to a growth rate of $1.5 \%$ for the 2001 to 2010 period for rice and wheat. The annual increase in demand for food grains in India is projected to be 5\% to $6 \%$ per annum. The Indian Ministry of Agriculture has reportedly asked for funding to develop new varieties of wheat and rice that consume $30 \%$ to $40 \%$ less water than traditional varieties. ${ }^{230}$

The Prime Minister's Council on Climate Change issued a National Action Plan on Climate Change in 2008 that envisaged a gradual shift to greater reliance on sustainable sources of energy with an emphasis on solar power, but India has not made a commitment to binding carbon emissions cuts. ${ }^{231}$ In announcing the National Action Plan, Prime Minister Dr. Manmohan Singh pointed out that in order to eradicate poverty in India there was a necessity for rapid economic growth but added that "I also believe that ecologically sustainable development need not be in contradiction to achieving our growth objectives." ${ }^{232}$ The Plan has eight key components: (1) solar; (2) enhanced energy efficiency; (3) sustainable habitat; (4) water; (5) sustaining the Himalayan ecosystem; (6) "Green India"; (7) sustainable agriculture; and (8) strategic knowledge on climate change. A report titled "Environment and Energy Sustainability: An Approach for India," published by McKinsey Co. in 2009 has estimated that India could reduce its carbon footprint by half by 2030 through significant investment in energy efficiency. ${ }^{233}$ The Prime Minister's Council on Climate Change announced in 2011 that it approved a National Mission for a Green India Initiative with plans for significant investment in India's forests. ${ }^{234}$

Despite the likely negative consequences of climate change and some moves to place new emphasis on renewable sources of energy in its energy mix, India has not taken a leadership role in addressing climate change on the world stage. As a developing economy that long suffered underdevelopment due to its colonial subjugation under the British, India is reluctant to undertake measures that it feels will hinder or slow its economic development for a problem it believes was largely caused by the West. India notes the fact that, on a per capita basis, its emissions are low. Indians emit 1.16 tons of $\mathrm{CO}_{2}$ on a per capita basis as compared to 19.78 for the United States,

\footnotetext{
229 "Agricultural Growth Key to Food Security," Business Times (Mumbai), June 10, 2010; "Indian Land Seriously Degraded,” BBC News, August 12, 2009 “India’s Water Use Unsustainable,” BBC News, August 13, 2009.

230 "Securing Food for an Emerging India," Business Line (Mumbai), April 4, 2011; "India Needs Rs 1,08,000 Crore For Food Security," Hindustan Times (Delhi), March 14, 2011.

${ }^{231}$ Prime Minster's Council on Climate Change, National Action Plan on Climate Change, Government of India, 2008.

"India Unveils Climate Change Plans," BBC News, June 30, 2008.

${ }^{232}$ Shyam Saran, Special Envoy of the Prime Minister for Climate Change, "India's Climate Change Initiatives," Address to The Carnegie Endowment for International Peace, March 24, 2010, Washington, DC.

233 Joe Leahy, "India Could Half Emissions by 2030," Financial Times (London), September 9, 2009.

${ }^{234}$ M. Somasekhar, "Save Forests Because They Serve Us" (op-ed), Business Line (Mumbai), June 5, 2011.
} 
9.66 for the United Kingdom, and 4.58 for China according to one source. ${ }^{235}$ While very low at present, India's $\mathrm{CO}_{2}$ emissions are projected to rise significantly to 3-3.5 tons annually by 2030 .

Climate change is an issue that has the possibility to create tensions between India and the West at a time when the United States has been seeking a closer relationship with India and will likely require adept diplomacy to bring India along in global efforts to address the problem. India shares with China the fear that global efforts to contain carbon emissions will hinder its economic development. This commonality of interests with China was made evident by their dual opposition to European efforts to obtain meaningful binding carbon emissions reductions at the December 2009 U.N. Climate Conference in Copenhagen. ${ }^{236}$ China and India subsequently signed the last-minute agreement that emerged from the summit. ${ }^{237}$ The Copenhagen Accord calls for limiting global temperature rise to no more than 2 degrees Celsius beyond preindustrial levels, but is not legally binding. ${ }^{238}$

The United States and India have begun working together on energy efficiency and carbon reduction projects. In November 2009, the U.S. and India announced that they would work together to jointly develop clean coal technologies, smart grids, and increased energy efficiency. ${ }^{239}$ Prime Minister Singh and President Obama launched a Clean Energy and Climate Change Initiative as part of their reaffirmation of their global strategic partnership. ${ }^{240}$ The November $2009 \mathrm{MoU}$ is to Enhance Cooperation on Energy Security, Energy Efficiency, Clean Energy and Climate Change. ${ }^{241}$

India shares China's position that the Kyoto Protocol should be extended when it expires in 2012 to lock in commitments by developed states to cut emissions. While India has pledged reductions under the Copenhagen accord it is not subject to binding reductions. Developed states sought to shape a successor agreement to Kyoto that would be legally binding and would replace the Kyoto Protocol during the October 2010 meeting of 177 governments in Tianjin, China. Many in the United States and other developed nations want India and China to accept firm emissions goals which they have resisted. ${ }^{242}$ A key tension in the talks has been the view by developing nations that the developed world needs to do more because the bulk of carbon emissions since the beginning of the industrial revolution have been caused by developed nations. ${ }^{243}$

\footnotetext{
235 “Global Warming," Union of Concerned Scientists, http://www.ucsusa.org.

${ }^{236}$ Tobias Rapp, "How China and India Sabotaged the UN Climate Summit," Spiegel (Berlin), May 5, 2010.

${ }^{237}$ Damian Carrington, "China and India Join Copenhagen Accord," Guardian (London), March 9, 2010.

${ }^{238}$ John Broder, "Climate Goal is Supported by China and India," New York Times, March 9, 2010.

239 "India-U.S. Cooperation in the Field of Energy," Press Information Bureau, November 13, 2009.

240 "India and the United States: Partnership for a Better World," Joint Statement Between Prime Minister Singh and President Obama, November 24, 2009.

241 “U.S., India on Energy Security, Climate Change Cooperation," America.gov, November 30, 2009.

242 "Climate Talks Struggle as China, US Face Off," Reuters, October 6, 2010.

${ }^{243}$ Chris Buckley, "US Says Climate Talks Fail to Make Headway,” Reuters, October 6, 2010.
} 


\section{Security-Related Issues}

\section{The Indian Military}

\section{Overview and Strategy}

India is in the midst of transforming its military into one with global reach. With more than 1.3 million active personnel, India's is the world's third-largest military (after China and the United States). ${ }^{244}$ New Delhi's defense budget rose above $\$ 38$ billion for 2010, a nearly $12 \%$ increase over the previous year. Another $11.6 \%$ boost is proposed for FY2011/12, but this increase would be partially mitigated by high rates of inflation. ${ }^{245}$ The army-more than one million strong and accounting for about half of the total budget - has traditionally dominated, but the navy and air force are becoming more important as India seeks to project its power and protect an Exclusive Economic Zone of more than two million square kilometers. For 2011, the air force procurement budget of $\$ 6.8$ billion accounts for about half of the service-specific total, with the army receiving $\$ 4$ billion and the navy another $\$ 3$ billion. ${ }^{246}$ The late 2008 Mumbai terrorist attacks elicited a spike in Indian security spending, including plans to enhance the navy's surveillance capabilities, across-the-board strengthening of the National Security Guard (NSG) counterterrorism force, and the raising of 29 new Border Security Force battalions (elite NSG commandos now operate from four new regional hubs - in Chennai, Hyderabad, Kolkata, and Mumbai-to improve response time in emergencies).

In 2010, Indian defense planners were seen to be focusing much more attention on China, a apparent shift from their decades-long Pakistan-specific planning. A much-discussed "Cold Start" doctrine, informally aired in 2004, apparently represents an Indian effort to address the escalatory problems posed by Pakistan's nuclear deterrent and the perceived inability of the Indian military to respond effectively to Pakistani provocations in 2002. It calls for the establishment of smooth interservices coordination and forward deployments that would allow for rapid but limited retaliatory strikes by "integrated battle groups." Observers in Islamabad and elsewhere see in the doctrine an offensive military strategy with the potential to destabilize the region's fragile strategic balance. $^{247}$

Although the Cold Start concept was discussed by India's Army Chief until 2008, Indian military leaders now officially deny that any such doctrine exists. Yet leaked U.S. diplomatic cables reportedly confirm at least indirect Indian government endorsement of the doctrine. Moreover, these documents may exhibit widespread doubts about Cold Start's efficacy held in both New Delhi and Washington, based in particular on limited Indian government support for the doctrine, potentially serious logistical problems with its execution, and worries that it could heighten the risk of escalation above the nuclear threshold, among others. ${ }^{248}$ Moreover, some reports indicate

\footnotetext{
${ }^{244}$ Additional paramilitary forces number about 1.3 million, with the Home Ministry overseeing most of these, notably the State Armed Police (450,000), the Central Reserve Police Force (230,000), the Border Security Force $(208,000)$, the Rashtriya Rifles $(65,000)$, the Assam Rifles $(64,000)$, and the Indo-Tibetan Border Police $(36,000)$. A total of 23 new paramilitary battalions were raised in the most recent fiscal year.

${ }^{245}$ The Military Balance 2011 (Institute for International and Strategic Studies, London, 2011); "With an Eye on China, India Steps Up Defense Spending," Reuters, February 28, 2011.

246 "India Defense Budget," Jane’s Defense Budgets, May 31, 2011.

${ }^{247}$ See Walter Ladwig III, “A Cold Start for Hot Wars?,” International Security, Winter 2007/2008.

248 “India Has No Cold Start Doctrine, Says Army Chief," Statesman, (Delhi), December 3, 2010; “The Collapse of (continued...)
} 
that the doctrine has come under criticism from top American military commanders and Administration officials who view it as a source of further India-Pakistan tension and thus as a hindrance of the U.S. military effort in Afghanistan. ${ }^{249}$

\section{Defense Equipment and Procurement ${ }^{250}$}

The Indian army operates more than 4,100 main battle tanks, the majority of them Russian-built $\mathrm{T}-72 \mathrm{~s}$ and T-55s, and some 4,000 towed artillery tubes. The navy has grown rapidly in recent years, currently operating 23 principal surface combatants (including one aircraft carrier) and 16 submarines. There also is a significant amphibious capacity: 17 landing ships (including one acquired from the United States) can carry 4,000 troops or 88 tanks. The navy has developed an indigenous nuclear-powered attack submarine (INS Arihant) to be armed with nuclear-tipped cruise missiles, and it also plans to lease a Russian Akula-class boat in 2011 as part of its "seabased strategic deterrence." $" 251$ The air force flies some 655 combat-capable aircraft, the majority of them Russian-built MiGs, but also including 122 late-model Su-30 MKIs, as well as Frenchbuilt Mirage and Anglo-French Jaguar aircraft. It also possesses modest airborne early warning and in-flight refueling capabilities provided by Russian-made platforms. A Strategic Forces Command oversees as many as 180 intermediate- and 280 short-range ballistic missiles capable of delivering nuclear warheads, and has plans to field a new Agni-IV missile with a range that would give it intercontinental capabilities. A three-stage, 5,000-km-range Agni-V is set to be tested in late 2011.

The Stockholm International Peace Research Institute named India as the world's largest weapons importer - accounting for fully $9 \%$ of the world's total arms imports from 2006 to 2010 - a designation the country is likely to keep for the foreseeable future. ${ }^{252}$ Current army programs concentrate on tank and missile acquisitions; the navy is pursuing major aircraft carrier and submarine programs; and the air force is seeking to procure more than 100 additional advanced, Russian-made Su-30 fighters, along with upgradation of its fleet of French-built Mirage ground attack aircraft. ${ }^{253}$

Russia continues to provide the bulk of India's imported defense wares. Moscow does not require enduse monitoring agreements for most arms sales as does Washington. This has made Russia an appealing supplier for India, which in the past has been willing to accept less advanced technology in return for both lower costs and fewer doubts about supplier reliability. More recently, however, India's rapid economic growth has provided New Delhi with larger

\footnotetext{
(...continued)

Cold Start," India Today (Delhi), December 13, 2010.

249 "Indian Contingency Against Pakistan Worries U.S.," New York Times, November 6, 2010.

${ }^{250}$ Most military data in this section come from The Military Balance 2011 (Institute for International and Strategic Studies, London, 2011).

${ }^{251}$ India's Navy Chief has stated that Arihant, launched in mid-2009 and currently undergoing sea trials, will by early 2012 by fully capable of operating with sea-launched ballistic missiles, thus completing the third leg of the country's nuclear triad ("In a Year, India Will Have Nuclear Triad: Navy Chief," Times of India (Delhi), December 3, 2010).

${ }^{252}$ SIPRI press release, March 14, 2011. See also CRS Report R41403, Conventional Arms Transfers to Developing Nations, 2002-2009, by Richard F. Grimmett.

253 “India Defense Budget," Jane's Defense Budgets, February 7, 2011. In July 2011, the New Delhi government approved French proposals worth more than $\$ 3$ billion for upgrades that would add at least two decades of operational life to its fleet of 51 Mirage jets.
} 
procurement budgets and thus an ability to purchase the most advanced weaponry on the market. ${ }^{254}$ In recent years, Israel has roughly equaled Russia in the value of defense exports to India-arms trade with Israel now tops $\$ 2$ billion annually and, like Russia, Israel does not impose political conditions on purchases. Moreover, India and Israel are engaging in new joint development projects involving missile technology.

New Delhi increasingly seeks to shift advanced military imports from finished platforms to coproduction with foreign suppliers. Under a license arrangement with Russia, India's Hindustan Aeronautics Limited is building hundreds of advanced Su-30 MKI ground attack jets. A 2005 deal with France provides for technology transfers and Indian construction of six Scorpene submarines to be delivered in 2015-2017. In seeking to replace its aging arsenal of MiG-21 fighters, India plans to purchase up to 186 new jets (126 for the air force and 60 for the navy) and has signaled a desire for technology sharing and co-production in this effort: only 18 of the new air force jets are to be manufactured abroad. In addition to the Scorpene submarines, other notable recent purchases for the Indian military include 347 of the latest Russian T-90 tanks (with another 1,000 such tanks to be built in India under a technology-sharing agreement) and upgrades on 600 existing T-72s; 3 new Russian-built missile frigates; 24 new MiG-29K naval jets for deployment on the INS Vitramaditya (formerly the Russian Gorshkov); 42 additional upgraded Su-30s, major upgrades on existing MiG and Jaguar aircraft; and 66 jet trainers from Britain.

Some analysts predict that, in the absence of major policy and organizational adjustments, India's efforts to modernize its armed forces will have little or no impact on the country's overall capacity to address security threats. Among the recommended changes are development of a more transparent and efficient procurement process, creation of a new Chief of Defense Staff position (to better integrate interservices planning), and the opening of India's defense research agencies to greater oversight. ${ }^{255}$ Although improvements in the procurement system have been effected, transparency and corruption continue to plague the process.

\section{Separatism in the Jammu and Kashmir State}

Although India suffers from several militant regional separatist movements, the Kashmir issue has proven the most lethal and intractable. It also poses the most serious international dilemma, given competing territorial claims with Pakistan. Gun battles and bomb blasts in India's Jammu and Kashmir state reportedly killed an average of five or six people every day over the period 1989-2006. ${ }^{256}$ Conflict over Kashmiri sovereignty also has brought global attention to a potential "flashpoint" for interstate war between nuclear-armed powers. Yet-despite a peaceful uprising in the summer of 2008, a resurgence of international attention to the issue following the late 2008 terrorist attack in Mumbai, and another round of sometimes lethal street demonstrations in mid2010 - the number of militant incidents in the state has been falling continuously and is now at its

\footnotetext{
${ }^{254}$ Sunil Dasgupta and Stephen Cohen, “Arms Sales for India: How Military Trade Could Energize U.S.-India Relations," Foreign Affairs, March 2011.

${ }^{255}$ See Stephen Cohen and Sunil Dasgupta, “The Drag on India’s Military Growth,” Brookings Institution Policy Brief \#176, September 2010.

256 “India Says Kashmir Toll Over 41,000, Others Differ,” Reuters, December 7, 2006. In 1999, a bloody, six-weeklong battle in the mountains near the LOC at Kargil cost more than one thousand lives and included Pakistani army troops crossing into Indian-controlled territory.
} 
lowest point since the violence began. Critics continue to accuse New Delhi of using brutal tactics to squash true democracy in the region. ${ }^{257}$

India has long blamed Pakistan for supporting "cross-border terrorism" and for fueling a separatist rebellion in the Muslim-majority Kashmir Valley with arms, training, and militants through an "terrorism infrastructure" on the Pakistani side of the LOC. Islamabad, for its part, claims to provide only diplomatic and moral support to what it calls "freedom fighters" who resist Indian rule and suffer alleged human rights abuses in the region. New Delhi insists that the dispute should not be "internationalized" through involvement by third-party mediators and India is widely believed to be content with the territorial status quo. ${ }^{258}$ Islamabad has sought to bring external major power persuasion to bear on India, especially from the United States.

The longstanding U.S. position on Kashmir is that the issue must be resolved through negotiations between India and Pakistan while taking into account the wishes of the Kashmiri people. When asked about Kashmir while in New Delhi in November 2010, President Obama described a "longstanding dispute between India and Pakistan" upon which "the United States cannot impose a solution." He did, however, reiterate the U.S. government's willingness to play a role in reducing tensions in whatever way the two parties think appropriate. ${ }^{259}$ The United Nations refrains from playing a role in the Kashmir issue unless both India and Pakistan request its engagement.

\section{Background}

The Kashmir problem is rooted in competing claims to the former princely state, divided since 1948 by a military Line of Control (LOC) separating India's Muslim-majority Jammu and Kashmir state and Pakistan-controlled Azad [Free] Kashmir and Gilgit-Baltistan (formerly known as the Northern Areas) (see Figure 2). The dispute relates to the national identities of both countries: India has long sought to maintain its secular, multi-religious credentials, in part by successfully incorporating a Muslim-majority region, while Pakistan has since independence been conceived as a homeland for the subcontinent's Muslims. India and Pakistan fought full-scale wars over Kashmir in 1947-1948 and 1965. Some Kashmiris seek independence from both

\footnotetext{
${ }^{257}$ London-based Amnesty International released a March 2011 report decrying the Indian government's detention of up to 20,000 people under the 1978 Jammu \& Kashmir Public Safety Act (PSA), which allows for years-long detentions without trial. Amnesty contends that the PSA violates India's international human rights legal obligations by depriving detainees of rights otherwise applicable under Indian law (Amnesty International, “A 'Lawless Law': Detentions Under the J\&K Public Safety Act," March 2011). See also Mirza Waheed, "On Kashmir, India Acts as a Police State, Not as a Democracy" (op-ed), Guardian (London), May 29, 2011.

${ }^{258}$ The Indian government still officially claims the entire formal princely state. New Delhi officials reportedly forced India's distributors of Economist magazine to put a white sticker over a map of Kashmir appearing in a May 2011 issue, saying it incorrectly depicted a territorial dispute involving claims by India, Pakistan, and China. The magazine's publishes accused the Indian government of "hostile censorship" ("Economist Accuses India of Censorship Over Kashmir Map,” BBC News, May 24, 2011).

259 "Remarks by President Obama and Prime Minister Singh in Joint Press Conference in New Delhi, India," White House release, November 8, 2010. Many critical observers urge the U.S. government to be more active in pressing both India and Pakistan - whether overtly or, perhaps more effectively, in private - to settle their Kashmir dispute in the interests of regional stability, especially with regard to Afghanistan. At least one senior analyst argues that U.S. policy "sabotages" a process in which India's aspirations for major power status could be used as leverage in finding a settlement on Kashmir. First, the argument goes, U.S. policy does not address the political grievances underlying "terrorism." Second, it approaches the Kashmir issue as a bilateral dispute (between New Delhi and Islamabad), thus giving short shrift to Kashmiri concerns and "delegitimizing the only approach which would make Pakistani territorial concessions domestically acceptable" (Robert Grenier, "Losing Kashmir” (op-ed), Al Jazeera (online), July 14, 2010).
} 
countries. ${ }^{260}$ Spurred by a perception of rigged state elections in 1989, an ongoing separatist war between Islamic militants (and their supporters) and Indian security forces in Indian-held Kashmir is ongoing and has claimed tens of thousands of lives. ${ }^{261}$ Soon after the armed insurgency began, much of the Kashmir Valley's indigenous Hindu population fled. ${ }^{262}$ At least 8,000 Kashmiris have "disappeared" during the conflict; some of these may occupy the unmarked graves discovered in 55 villages over a three-year study. ${ }^{263}$

Some separatist groups, such as the Jammu and Kashmir Liberation Front (JKLF), continue to seek an independent or autonomous Kashmir. Others, including the militant Hizbul Mujahideen (HuM), seek union with Pakistan. ${ }^{264}$ In 1993, the All Parties Hurriyat [Freedom] Conference was formed as an umbrella organization for groups opposed to Indian rule in Kashmir. The Hurriyat membership of more than 20 political and religious groups has included the JKLF (originally a leading militant force, now a political group) and Jamaat-e-Islami (the political wing of the $\mathrm{HuM}$ ). The Hurriyat Conference, which states that it is committed to seeking dialogue with the Indian government on a broad range of issues, calls for a tripartite conference on Kashmir, including Pakistan, India, and representatives of the Kashmiri people. Hurriyat leaders demand Kashmiri representation at any talks between India and Pakistan on Kashmir. The Hurriyat formally split in 2003 after a dispute between hardliners allied with Islamabad and moderates favoring negotiation with New Delhi. Subsequent efforts to reunify the group failed. In 2005, the Congress Party-led government renewed high-level contact with moderate Hurriyat leaders begun by the previous BJP-led coalition. Two years later, however, Hurriyat leader and noted Kashmiri cleric Mirwaiz Umar Farooq said talks between the Indian government and moderate Kashmiri separatists had suffered a "complete breakdown of communication," and he accused New Delhi of lacking the will needed to find a political solution to the problem. ${ }^{265}$

\footnotetext{
${ }^{260}$ Both Kashmiri separatists and most of the Indian nationalists who insist that the territory is an integral part of India share a core belief that the Indian state represents a monolithic Hindu identity. For both sides, this belief thus provides an unshakeable justification for their respective causes (Rohini Hensmen, "Mapping the Debate," Outlook (Delhi), December 1, 2010).

${ }^{261}$ Most estimates list from 41,000 to 77,000 related deaths. The Pakistan-based Kashmir Media Service claims that more than 93,000 Kashmiris have been "martyred" in the fighting.

${ }^{262}$ During the early years of the Kashmir insurgency, hundreds of thousands of indigenous Hindu "Pandits" were driven from the region in what amounted to a form of "ethnic cleansing." Up to half a million Kashmiri Pandits, accounting for the vast majority of Hindus then living in the area around Srinagar, fled their homes after coming under threat from Muslim militants. For many Indians, the Kashmir dispute cannot be resolved without arrangements for the return of these refugees, more than 100,000 of whom continue to live in camps with government support. Resolutions in the $110^{\text {th }}$ Congress (H.Con.Res. 55 and S.Con.Res. 38), the $111^{\text {th }}$ Congress (H.Res. 1601), and the $112^{\text {th }}$ Congress (H.Res. 387) have called for the safeguarding of the physical, political, and economic security of Kashmiri Pandits.

263 "India: Investigate Unmarked Graves in Jammu and Kashmir," Human Rights Watch release, August 25, 2011.

${ }^{264}$ A 2007 public opinion survey found nearly 90\% of the residents of Srinagar, Kashmir's most populous and Muslimmajority city, desiring Kashmiri independence from both India and Pakistan. In the largely Hindu city of Jammu, however, 95\% of respondents said Kashmir should be part of India (see http://www.indianexpress.com/story/ 210147.html). A 2008 survey conducted in both India and Pakistan found a majority of respondents expressing an openness to a range of possible outcomes for Kashmir, including outright independence. While such an outcome was described as "unacceptable" by half of the Indians surveyed, the pollsters concluded that, "If a majority of all Kashmiris were to choose independence, a majority of Indians and Pakistanis would find such independence at least tolerable" (see http://www.worldpublicopinion.org/pipa/pdf/jul08/Kashmir_Jul08_rpt.pdf).

265 “Kashmiri Separatist Says India Talks Break Down,” Reuters, August 30, 2007.
} 
Figure 2. Map of Kashmir

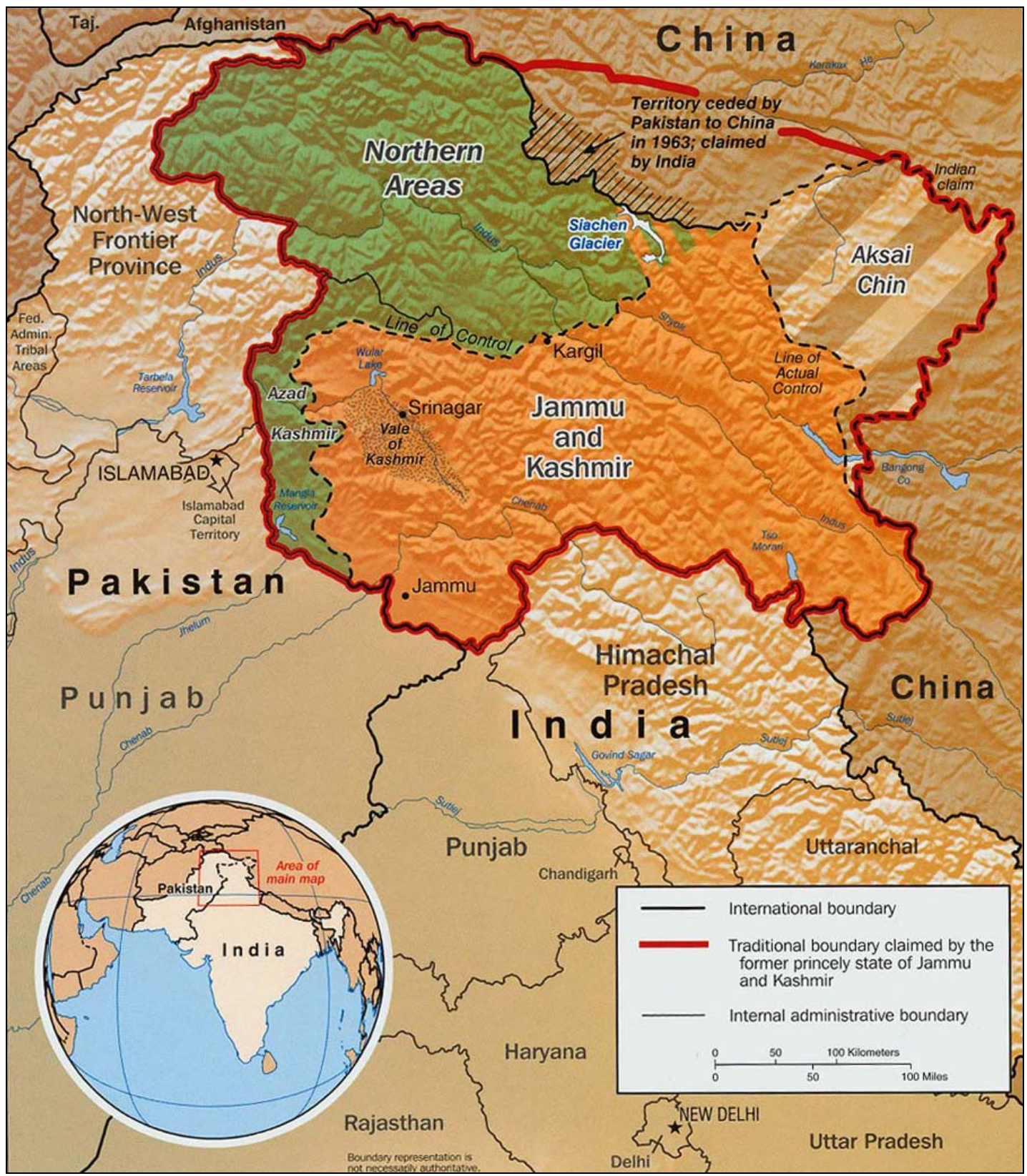

Source: CIA.

Note: Boundary representation is not necessarily authoritative.

Levels of violence in Kashmir were high and steady through the mid- and late 1990s, peaked in 2001, and have been in steady decline since (see Figure 3). The long-term reduction in violence has allowed for a rebirth of the scenic region's major tourist industry. Yet, despite waning rates of infiltration and separatist-related violence, the issue continues to rankle leaders in New Delhi and remains a serious impediment to progress in the current India-Pakistan peace initiative. Even as the normalization of India-Pakistan relations moves forward-and to some extent in reaction to their apparent marginalization in the face of this development - separatist militants continue their attacks on both civilians and Indian security forces, and many observers in both India and the 
United States believe that active support for Kashmiri militants remains Pakistani policy. The militants, seeing their relevance and goals threatened by movement toward peaceful resolution, still lash out with bloody attacks likely meant to derail the process.

Figure 3. Deaths Related to Kashmiri Separatist Conflict, 1988-20 I 0

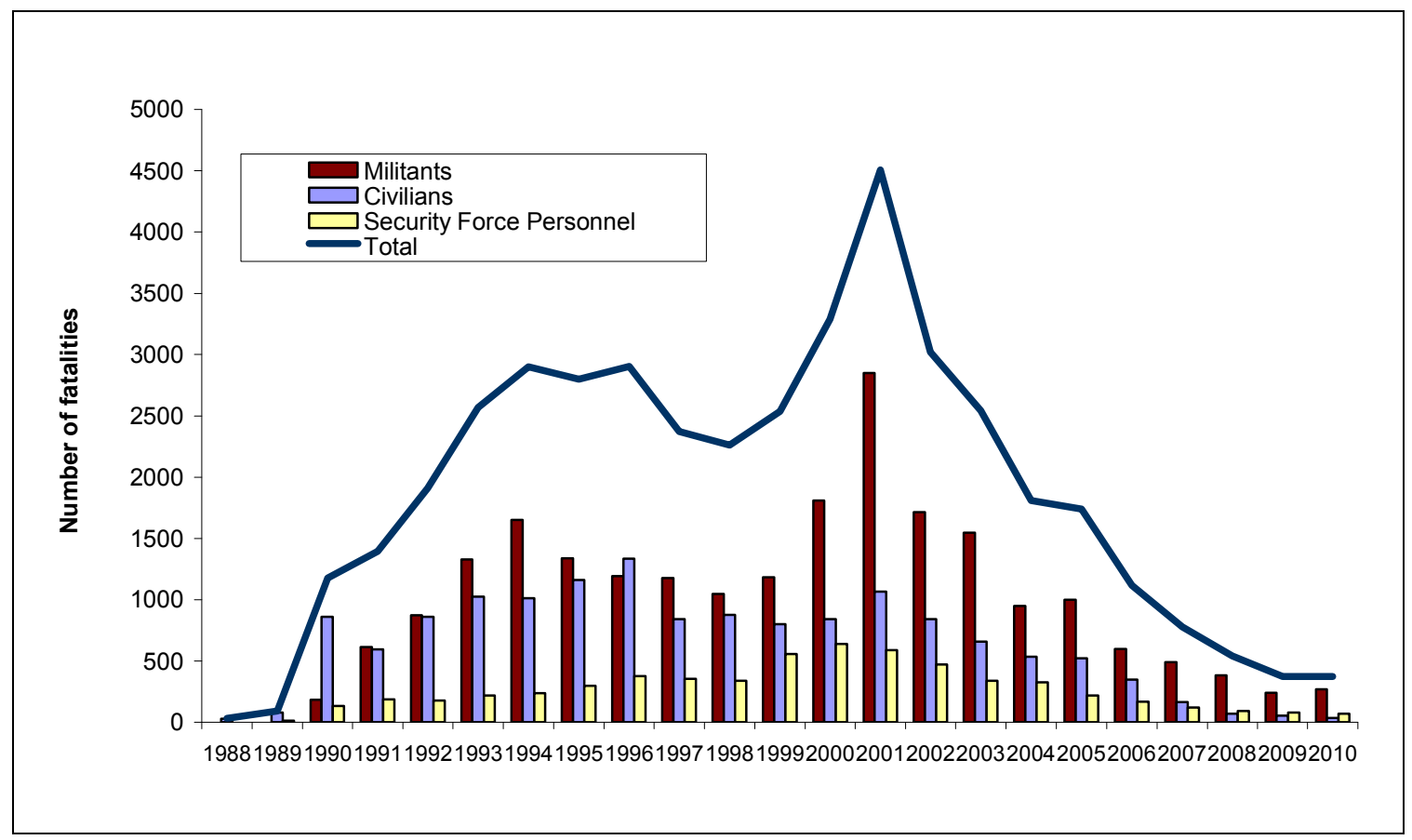

Source: Adapted by CRS. Data from the Institute for Conflict Management, New Delhi, India.

\section{Mid-2010 Uprising}

A more-or-less spontaneous resurgence of open separatist protest emerged in the summer of 2010. In June of that year, large-scale street protests led to violence and the deaths of several protestors in clashes with paramilitary police. Within weeks, regular Indian army troops were being deployed on the streets of Srinagar to restore and maintain order, yet civil unrest only increased and spread to other parts of Indian Kashmir, even as separatist leaders appealed for calm. By August, the unrest - comprised mainly of large numbers of youths hurling stones at security personnel — was being called a "full-blown separatist uprising" - the most serious challenge to central rule in two decades - and evidence grew that the current iteration of unrest represented a wider and more spontaneous movement than those in past years. New Delhi imposed an indefinite curfew in September, but the central government, along with that of the state's Chief Minister, Omar Abdullah, were seen to be flummoxed by the resilience and depth of resentment demonstrated by protestors. ${ }^{266}$ International human rights groups urged Indian government officials to avoid excessive use of force while investigating the deaths of children. ${ }^{267}$

\footnotetext{
266 "India Struggles to Contain Kashmiri Rage," Financial Times (London), July 15, 2010; "New Delhi Cogitates, Kashmir Burns," Wall Street Journal, September 15, 2010. Abdullah himself was criticized for being slow to recognize the extent of the problem and for appearing detached from his people's concerns, at considerable cost to his popularity ("Kashmir Chief is Target of Mounting Public Frustration," Time, August 16, 2010).

${ }^{267}$ See, for example, the July 2, 2010, Amnesty International statement at http://www.amnesty.org/en/library/info/ (continued...)
} 
Prime Minister Singh convened an all-parties meeting in September to discuss the crisis with opposition parties and announced modest efforts to reduce the presence of security forces and facilities in the region even as the Indian military continued to resist amendment or suspension of the controversial Armed Forces Special Powers Act (AFSPA) that is named by rights groups as a facilitator of abuses in Kashmir and elsewhere. In November, Chief Minister Abdullah ordered nearly 1,000 paramilitary Central Reserve Police Force personnel withdrawn from Srinagar as part of a peace initiative. Singh later contended the "troubled period" of summer 2010 street protests by youths highlighted the need for security forces to develop better nonlethal means of response, and he has directed his home ministry to prepare these. Meanwhile, Hurriyat leaders have discouraged any repeat of the protests; even hardline separatist leader Syed Ali Shah Geelani has come out against stone throwing as a form of resistance, saying it gives security forces "an excuse to kill" Kashmiris and that only peaceful resistance will forward his cause. ${ }^{268} \mathrm{Still}$, Srinagar and the surrounding Kashmir Valley have remained unsettled. ${ }^{269}$

\section{The Search for a Political Solution}

In October 2010, the UPA government appointed a trio of official and unofficial "mediators," but the team's composition was widely deemed to be disappointing. During the closing months of the year, the three interlocutors - senior journalist Dileep Padgaonkar, social activist Radha Kumar, and former information commissioner M.M. Ansari-made multiple trips to the state in an effort to find "a political solution for a political problem." 270 Some of their preliminary recommendations to Home Minister Chidambaram were made public in December and included

expediting cases of under-trials, permitting peaceful protests, releasing militants/protestors against whom there are no serious charges, training of security forces, identifying jobs for young men and women in Central/State Government offices, announcing scholarships for Kashmiri students, enhancing monetary assistance to widows and orphans, enhanced efforts to trace missing persons, promoting investments in Kashmir, ... increasing monthly allowances to Kashmiri Pandits, etc. ${ }^{271}$

\section{(...continued)}

ASA20/017/2010/en. Some critics of Indian policy in Kashmir compare it unfavorably to that of Israel in the West Bank, arguing that New Delhi should come suffer international opprobrium for its allegedly repressive tactics (see, for example, Rob Brown, “Why Isn’t India a Pariah State?” (op-ed), Jerusalem Post, September 19, 2010).

268 "PM's Address at the CMs' Conference on Internal Security," Prime Minister's Office release, February 1, 2011; "Geelani Rejects Stone Pelting," Indian Express (Mumbai), July 8, 2011.

${ }^{269}$ November 2010 saw an upsurge in anti-India street protests during the Muslim Eid Al-Adha festival. This unrest appears to have been spontaneous and was led by civilian rather than militant groups. Main opposition BJP leaders made a show of efforts to hoist the Indian flag in Srinagar on Republic Day in January 2011, but were ordered to desist by the state government with backing from the federal home ministry. More than 10,000 Hindu-nationalist protesters were physically blocked from entering the state capital and top BJP leaders were detained at the regional airport. Commerce in Srinagar was later halted in February 2011 when Gilani supporters protested his temporary detention by police investigating illegal money transfers.

270 "Disappointment With Team to Ease Kashmir Tension," Financial Times (London), October 13, 2010; "We Aim to Evolve a Dialogue Structure: J\&K Interlocutors," Hindu (Chennai), November 29, 2010.

${ }^{271}$ Indian Home Ministry press release, December 7, 2010. After a December visit to Kashmir, an 11-person delegation of Indian parliamentarians and civil society members expressed disappointment with what they called the central government's "non-serious" attitude in the face of concrete recommendations, and they emphasized a need to hold the state's security forces accountable for the deaths of more than 100 "innocent people" the previous summer ("J\&K Needs Immediate, Long-Term Measures,"” Hindu (Chennai), December 6, 2010). 
A final report is expected in September 2011. While the value of the interlocutor's efforts to meet with a wide spectrum of the state's population is generally acknowledged, two key weaknesses are identified in their approach. First, their interaction has been almost exclusively with Kashmiris who accept the state's status as a part of India; while their mandate officially includes dialogue with "separatists," this has not occurred in practice, and Hurriyat leaders have refused to meet with them. Second, these interlocutors have no mandate to interact with another major stakeholder: Pakistan. Given these two problems, any progress realized though this tack is likely to remain limited. ${ }^{272}$

Moreover, cynics contend that those most energetically seeking a "political solution" in Kashmir are often themselves the major obstacles to progress. The argument here is that the key breakthroughs such as the split among separatists into moderate and militant wings are made without the involvement of federal or state officials, and that the government's unilateral reductions in security force levels amount to "appeasement of extremist elements." From this perspective, resolution lies in maintaining pressure on violent, Pakistan-backed separatists, including the "stone-pelters" of mid-2010, while empowering moderate Hurriyat figures who are willing to disown the "terrorists" who have "hijacked" the movement, in part by having New Delhi's interlocutors meet directly with such figures. ${ }^{273}$

Kashmiri separatist leaders have themselves called New Delhi's efforts "cosmetic" and they continue to demand a blanket lifting of AFSPA, the withdrawal of army troops from the Valley, and the release of all political prisoners as preconditions for talks with the government. Chief Minister Abdullah has chided Hurriyat leaders for resisting talks with New Delhi's interlocutors while showing no hesitation for meeting with the Pakistani High Commissioner and Foreign Minister in the Indian capital. Abdullah is among many state politicians who believe dialogue with New Delhi is the only way forward for separatist leaders. ${ }^{274}$

Some of the separatist demands noted above also appear as suggestions in independent analyses, many of which emphasize economic development and political devolution as the best means of mitigating Kashmiri discontent. Indeed, economic uplift, perhaps in the form of a large-scale jobs program for the region, could be the most effective policy to address the growing numbers of disaffected Kashmiri youth. ${ }^{275}$ In 2011, New Delhi has sought to mollify Kashmiri anger with a "charm offensive" of sorts, including new job training programs, the launching of numerous cricket and soccer clubs in the Valley, language courses for Indian security forces to speak the local tongue, and blanket amnesty for the "stone-pelters" of mid-2010. Yet, while these initiatives

\footnotetext{
${ }^{272}$ Howard and Teresita Schaffer, "Kashmir: Is There a New Indian Policy?,” South Asia Hand (online), February 27, 2011.

${ }^{273}$ Ajai Sahni and Ajit Kumar Singh, "Politics in the Labyrinth," Outlook (Delhi), January 24, 2011. The fervor of militant separatists has become such that even their moderate erstwhile allies have come under violent attack. In one example, Kashmiri religious leader Maulana Shaukat Ahmed Shah, who had spoken out against the stone-pelting and ensuing violence of mid-2010, was assassinated in April 2011.

274 “Talk to New Delhi, Omar Tells Separatists," Hindu (Chennai), December 5, 2010; authors interview with Kashmiri politicians, Srinagar, January 2008.

${ }^{275}$ See, for example, Happymon Jacob, "Kashmir Needs a Political Package" (op-ed), Hindu (Chennai), September 23, 2010; Walter Anderson, "Understanding the Political Sociology of Violence in Kashmir," paper delivered at the Heritage Foundation, Washington, DC, October 7, 2010. See also "Solving the Kashmir Conundrum" (interviews), Council on Foreign Relations, October 15, 2010, at http://www.cfr.org/kashmir/solving-kashmir-conundrum/p21655.
} 
and smarter police tactics have kept the Valley calm in mid-2011, in the absence of a substantive political settlement, these measures are seen as conflict management only. ${ }^{276}$

\section{Maoist Rebellion, Other Insurgencies, and Communalism}

As a vast mosaic of ethnicities, languages, cultures, and religions, India can be difficult to govern. Internal instability resulting from diversity is further complicated by colonial legacies such as international borders that separate members of the same ethnic groups, creating flashpoints for regional dissidence and separatism. In addition to the violent, decades-old Kashmir dispute, Maoist rebels continue to operate in numerous states and represent a serious and growing threat to internal sovereignty. At the same time, separatist insurgents in remote and underdeveloped northeast regions confound New Delhi and create international tensions by operating out of neighboring Bangladesh, Burma, Bhutan, and Nepal. New Delhi has at times blamed the governments of those countries for "sheltering" separatist groups beyond the reach of Indian security forces, and New Delhi has launched joint counter-insurgency operations with some of these neighbors. India also has suffered outbreaks of serious communal violence between Hindus and Muslims, especially in the western Gujarat state.

More than half of India's 636 administrative districts are said to suffer from chronic activity by insurgent, terrorist, and/or separatist groups. The State Department's most recent Country Reports on Terrorism (released August 2011) found that, although rates of terrorist violence in India declined in 2010, "the loss of nearly 1,900 lives (civilian, security forces, and terrorists) still made India one of the world's most terrorism-afflicted countries." ${ }^{, 77}$

\section{Maoist Rebels}

Increasingly prevalent in India are "Naxalites"-Maoist insurgents ostensibly engaged in violent struggle on behalf of landless laborers and tribals. These groups, most active in inland areas of east-central India, claim to be battling oppression and exploitation in order to create a classless society. Their opponents call them terrorists and extortionists. The rebels get their name from Naxalbari, a West Bengal village and site of a militant peasant uprising in 1967. In 2006, Prime Minister Singh identified a worsening Maoist insurgency as "the single biggest internal security challenge" ever faced by India, saying it threatened India's democracy and "way of life." ${ }^{278} \mathrm{At}$ least 8,000 hardcore Naxalite fighters now operate in 20 of India's 28 states, more than one-third of the country's 636 administrative districts, and one-seventh of the country's 14,000 police districts. Related violence has killed more than 5,000 people over the six years, including more 1,000 deaths in both 2009 and 2010, the great majority of these in the states of West Bengal and Chhattisgarh. ${ }^{279}$ Analysts warn that, by blocking access to raw materials vital to India's manufacturing sector and deterring investors, the Naxalite movement could thwart India's longterm economic success.

\footnotetext{
276 "India Tries Sports, Job Training to Pacify Kashmir," Associated Press, May 6, 2011; "Why Kashmir is Quiet—For Now," Christian Science Monitor, August 2, 2011.

${ }^{277}$ State Department report at http://www.state.gov/documents/organization/170479.pdf.

278 “Indian PM Says Maoist Rebellion Gravest Threat," Reuters, April 13, 2006.

${ }^{279}$ Ajai Sahni, "Inertial Advantage" (op-ed), Outlook (Delhi), February 18, 2011. See data sheets at http://www.satp.org/satporgtp/countries/india/maoist/data_sheets/fatalitiesnaxal.asp.
} 
The most notable of India's Maoist militant outfits are the People's War Group (PWG), emanating from the southern Andhra Pradesh state, and the Maoist Communist Center of West Bengal and Bihar. In 2004, the two groups merged to form the Communist Party of India (Maoist). Both have appeared on the U.S. State Department Counterterrorism Office's list of "groups of concern" and both are designated as terrorist organizations by the New Delhi government.

In 2005, the Chhattisgarh state government began sponsoring a grassroots anti-Maoist effort. This "Salwa Judum" ("Campaign for Peace" or, literally, "collective hunt") militia-comprised of some 5,000 lightly-armed tribals paid about \$1 per day-was viewed by some as an effective countervailing people's movement. Others labeled it a vigilante group that engaged in its own coercive and violent tactics against innocent tribals, serving only to accentuate the conflict as "a cure that is worse than the disease." 280 A 2008 report for India's Planning Commission contended that the Salwa Judum campaign represented "an abdication of the state itself" and should immediately cease. New York-based Human Rights Watch later called on the New Delhi and Chhattisgarh governments to end all official support for the campaign, including provision of weapons, and to launch "serious and independent investigations" of related human rights abuses. ${ }^{281}$ In July 2011, India's Supreme Court barred Chhattisgarh from arming tribal militias to fight the Maoists, calling the renamed Special Police Officers "cannon fodder."282

The New Delhi government has sought to undermine the Maoist rebellion in part by boosting development spending in affected areas. Yet unsettled debate among national-level political leaders between those favoring a militarized counterinsurgency effort versus those calling for a development/welfare approach may be hindering New Delhi's anti-Maoist policies. Naxalite activity-including swarming attacks on government facilities and coordinated, multi-state economic blockades - is spreading and becoming more audacious in the face of incoherent and insufficient Indian government policies to halt it. A shortage of police personnel appears to be a key problem; the rebels are able to attack in large enough numbers that most police units, oftentimes fighting with inferior weapons, are rendered helpless. ${ }^{283}$

Top Indian leaders continue to identify Maoist rebels as the leading domestic security threat and some 60,000 paramilitary forces (the Central Reserve Police Force) have been deployed to combat them in several affected states. ${ }^{284}$ In mid-2010, New Delhi announced that it would increase its assistance to state governments through the provision of more helicopters, the establishment or strengthening of 400 police stations, and the improvement of road connectivity in affected areas, among other measures. It also asked the governments of the four most-affected states (Chhattisgarh, Jharkhand, Orissa, and West Bengal) to create a Unified Command for antiNaxal operations. However, these efforts do not address the "intellectual appeal" of the Maoists, which India's former national security advisor has identified as a key problem.

\footnotetext{
${ }^{280}$ Asian Center for Human Rights press release, January 10, 2007.

281 "Scrap Sulwa Jundum: Planning Commission Panel," Hindu (Chennai), May 21, 2008; July 2008 HRW report at http://www.hrw.org/reports/2008/india0708/india0708webwcover.pdf.

282 "Rap on Rights Violation in Maoist Fight," Telegraph (Kolkata), July 6, 2011.

283 “Maoists Gun Down 11 Security Personnel," Telegraph (Kolkata), May 4, 2011. In May, nearly 250 Maoist militants ambushed a 10-man police team near the Chhattisgarh-Orissa border and killed all but one of them.

284 "Pranab Sees Naxalism as the Biggest Threat to Nation's Security and Peace," Hindu (Chennai), December 29, 2010.
} 
In February 2011, Prime Minister Singh noted that, while the incidence of Maoist violence had been somewhat reduced in 2010, the number of civilian casualties in such violence increased that year, and he listed Naxalite activity in six states - Chhattisgarh, Bihar, West Bengal, Jharkhand, Orissa, and Maharashtra - as being of serious concern. His government currently seeks to implement an "Integrated Action Plan" for 60 districts in affected areas that will allow substantive district-level control of resources. ${ }^{285}$ Maoist militants continue to stage sometimes spectacular attacks on both civilian and security targets, indicating that their capabilities are only growing (perhaps most notable among these was an April 2010 ambush in Chhattisgarh's Dantewada district that killed 75 Indian paramilitary soldiers). According to New Delhi's Institute for Conflict Management, Maoist-related violence in India during the first half of 2011 left an average of two people dead every day. ${ }^{286}$

\section{Separatism and Insurgency in the Northeast}

Since the time of India's foundation as an independent nation, numerous militant groups have fought for greater ethnic autonomy, tribal rights, or independence in the country's northeast region. Some of the tribal struggles in the small states known as the Seven Sisters are centuries old; there are more than 200 ethnic groups in India's northeast alone. More than 50,000 people are estimated to have been killed in such fighting since 1948, including about 20,000 deaths in a 30 -year-old Naga insurgency and another 10,000 deaths in 17 years of fighting in the Assam state. ${ }^{287}$ In the small state of Manipur alone there are said to be more than 20 separatists groups fighting the Indian army at a cost of more than 8,000 lives over two decades, and the writ of the central government there remains tenuous in many areas.

As militant groups are seen to benefit from highly profitable criminal activities such as informal taxation, kidnapping, and smuggling, many observers conclude that only more effective economic development and integration of India's northeast will allow for the resolution of myriad ethnic conflicts there. In a possible indication that such policies are being effective, fatalities linked to separatist militancy in the northeast fell dramatically in 2010 as compared with the previous year (from 852 to 322), with the historically most-affected states of Manipur and Assam enjoying particularly strong improvements in the security situation. ${ }^{288}$

The United Liberation Front of Assam (ULFA), the National Liberation Front of Tripura, the National Democratic Front of Bodoland, and the United National Liberation Front (seeking an independent Manipur) are among the approximately 40 northeastern militant groups warring with the central government. They reportedly field a total of no more than 20,000 trained cadres. ULFA, like other groups, accuses New Delhi of exploiting their state's resources while doing little to forward development and allowing thousands of non-indigenous people (often Hindi-

285 "PM's Address at the CMs' Conference on Internal Security," Prime Minister's Office release, February 1, 2011.

${ }^{286}$ See data sheets at http://www.satp.org/satporgtp/countries/india/maoist/data_sheets/fatalitiesnaxal.asp.

${ }^{287}$ Some analysts see links between Chinese intelligence agencies and insurgent groups in India's northeast, in particular those seeking an independent Nagaland. Press reports indicate that Norinco, a large, state-owned Chinese weapons manufacturer, has emerged as a key supplier of arms to separatist militants in Nagaland and Manipur (Lyle Morris, "Is China Backing Indian Insurgents?," Diplomat (Tokyo), March 22, 2011; “Gunrunners of Northeast," India Today (Delhi), June 6, 2011).

${ }^{288}$ South Asia Terrorism Portal data at http://www.satp.org/satporgtp/countries/india/database/ fatalitiesnorteast2006.htm. According to the Home Ministry, the number of separatist "incidents" in the northeast in 2010 was down by $40 \%$ from 2009 (from 1,297 to 773) and the number of related civilian deaths was down by $64 \%$ (from 264 to 94 ) (see http://mha.nic.in/pdfs/AR(E)1011.pdf). 
speakers from Bihar) to flood the local job markets. In 2005, the U.S. State Department's Counterterrorism Office listed ULFA among its "other groups of concern," the first time an Indian separatist group outside Kashmir was so named. ${ }^{289}$ In September 2011, the central government and ULFA signed a mutual ceasefire agreement pending political settlement of their dispute.

\section{Communal Tensions and Conflict}

Hindu-Muslim Conflict. Some elements of India's Hindu majority have at times engaged in violent communal conflict with the country's large Muslim minority of some 150 million, which is relatively poor, uneducated, and underrepresented in professions such as law and medicine. In 1992, a huge mob of Hindu activists in the western city of Ayodhya demolished a $16^{\text {th }}$-century mosque said to have been built at the birth site of the Hindu god Rama. Ensuing communal riots left many hundreds dead in cities across India. Mumbai was especially hard hit as the site of coordinated 1993 terrorist bombings believed to have been a retaliatory strike by Muslims. ${ }^{290}$ In 2002, another group of Hindu activists returning by train to the western state of Gujarat after a visit to the Ayodhya site of the now razed Babri Mosque (and a proposed Hindu temple) were attacked by a Muslim mob in the town of Godhra; 58 were killed. Up to 2,000 people died in the fearsome communal rioting that followed, most of them Muslims. The BJP-led state and national governments came under fire for inaction; some observers saw evidence of state government complicity in anti-Muslim attacks. In February 2011, a court found 31 Muslims guilty of setting fire to the train; another 63 people were acquitted. Of those convicted, 11 were sentenced to death and the remaining 20 to life imprisonment.

The U.S. State Department and human rights groups have been critical of New Delhi's largely ineffectual efforts to bring those responsible for the post-Godhra rioting and murders to justice; some of these criticisms were echoed by the Indian Supreme Court in 2003. In 2005, the State Department made a controversial decision to deny a U.S. visa to Gujarat Chief Minster Narendra Modi under a U.S. law barring entry for foreign government officials found to be complicit in severe violations of religious freedom. ${ }^{291}$ The decision was strongly criticized in India. In 2008, a Gujarat state government commission exonerated Modi, claiming to have found "absolutely no evidence" that he or his ministers had acted improperly. More than nine years after the Gujarat riots, international human rights groups express concerns about obstacles faced by victims seeking justice, the continuing internal displacement of thousands of families who lack basic necessities, and large numbers of uninvestigated related criminal cases (despite the Indian Supreme Court's 2004 order to reopen nearly 1,600 such cases). In September 2010, the Allahabad High Court issued a much-anticipated ruling on the Ayodhya site, determining that Hindus and Muslims should share the land. Expected large-scale communal violence did not occur. However, in May 2011, India's Supreme Court suspended the ruling, saying it had opened the doors to a flood of unnecessary litigation.

\footnotetext{
${ }^{289}$ See http://www.state.gov/s/ct/rls/crt/2005/65275.htm.

${ }^{290}$ Dawood Ibrahim, a most-wanted organized crime figure accused masterminding the 1993 bombings that left some 250 people dead, is widely believed to be finding refuge in Karachi, perhaps with the knowledge/protection of Pakistan's intelligence service (“The Sultan Doesn't Live Here Anymore," India Today (Delhi), June 6, 2011).

${ }^{291}$ In 2007, Human Rights Watch called on the Indian government to launch an investigation of Modi after he made statements apparently endorsing the extrajudicial execution of a terrorism suspect by police. In 2008, 27 Members of the U.S. Congress joined the U.S. Commission on International Religious Freedom in urging the State Department to reaffirm its past decision to block Modi's entry to the United States ("India: Gujarat Chief Minister Endorses Unlawful Killings," Human Rights Watch release, December 7, 2007).
} 
Indigenous Islamist Terrorism. Despite New Delhi's reluctance to openly acknowledge the fact, India also has its own indigenous Islamist terrorism threat. The newly emergent "Indian Mujahideen" (IM) group, widely believed to be an offshoot or pseudonym of the Students Islamic Movement of India (SIMI), has been found complicit in a number of recent bombings, even as government leaders continue to name Pakistan as an abettor of such episodes. The New Delhi government formally outlawed the IM in 2010; months later, the group claimed responsibility for a December bombing in the Hindu holy city of Varanasi that left a child dead and at least 20 people injured. In July 2011, three synchronized bomb blasts killed 17 people and injured some 130 more during Mumbai's evening rush hour. No credible claims of responsibility were received and, to date, Indian officials have refrained from naming any specific foreign or domestic groups as suspects, but the coordinated bombings appear to have required sophisticated explosives training (Pakistan's two top leaders had immediately condemned the attack). Early indications are that the perpetrators were India-based, perhaps from the IM, rather than from a Pakistan-based group. ${ }^{292}$

Some Indian experts assert that the IM's top operators, drawn mostly from SIMI's ranks, receive training at camps inside Pakistan. ${ }^{293}$ Prime Minister Singh acknowledged in 2008 that the involvement of "local elements" in terrorist attacks added a "new dimension" to the country's indigenous militancy problem. ${ }^{294}$ SIMI may be viewed in alignment with the greater international jihadi movement, given its endorsement of the goals of Al Qaeda and its links with other international terrorist groups such as the Pakistan-based Lashkar-e-Taiba and Harakat-ul-JihadIslami. As India's Muslim minority continues to suffer from glaring social inequities, it is likely that some among its numbers will remain vulnerable to recruitment in SIMI and/or the IM. ${ }^{295}$

Indigenous Hindu Terrorism. Even more recent are overt signs that India is home to militant Hindu nationalist groups intent on launching domestic terrorist attacks. In September 2008, seven people were killed by two bomb blasts in the Maharashtran city of Malegaon, a hotbed of HinduMuslim communal strife. By year's end, police had arrested nine members of a "Hindu terrorist cell" in connection with the bombing, including an active army lieutenant colonel and a Hindu nun with links to the main opposition BJP. ${ }^{296}$ Thus did "Hindu terrorism" become a new and highly controversial phrase in India's national dialogue. Never before in the country's history had the phrase been so widely used, and the development had major and continuing effects on India's national psyche. Many Indian observers warned of the danger of a "militant majoritarianism" among Hindu nationalists that threatens to rend the secular fabric of the nation. ${ }^{297}$

In late 2010, Hindutva extremist Swami Aseemanand confessed to involvement in a number of terrorist attacks previously blamed on Islamist militants, including the 2006 bombing of a Muslim cemetery in Malegaon that killed 37 people and the 2007 bombing of the transborder Samjhauta Express, a train linking Delhi and Lahore, Pakistan, that killed 68 people, most of them Pakistani

\footnotetext{
292 “Officials Say Bombers in Attack on Mumbai Had Some Training,” New York Times, July 14, 2011.

293 “India's Al Qaeda," India Today (Delhi), December 22, 2008.

294 “Indian PM Worries About Home-Grown Militant Threat,” Reuters, September 17, 2008.

${ }^{295}$ C. Christine Fair, "Students Movement of India and the Indian Mujahideen: An Assessment," Asia Policy, January 2010. See also Praveen Swami, "The Rebirth of the Indian Mujahideen," Hindu (Chennai), April 19, 2010.

296 "India Police Say They Hold 9 From Hindu Terrorist Cell,” New York Times, November 12, 2008.

297 “"Hindu Terrorism' Debate Grips India,” BBC News, November 21, 2008; Praful Bidwai, "Saffron Terror” (op-ed), Frontline (Chennai), November 21, 2008; "The True Face of the BJP” (op-ed), Outlook (Delhi), October 29, 2008. See also "The Rise of Hindutva Terrorism," Outlook India (Delhi) May 11, 2010.
} 
civilians. Aseemanand said these and other attacks were to avenge Islamist terrorist attacks on Hindu temples. The confessions were an embarrassment for law enforcement agencies that had arrested Muslim suspects, and gave credibility to analysts who identify Hindu militancy as a threat to India's security. ${ }^{298}$

Hindu-Christian Conflict. In 2008, lethal attacks on Orissa Christians erupted in apparent retaliation for the murder of a prominent local Hindu leader. Police blamed the murder on Maoist rebels, but Hindu radicals blamed local Christians. Rampaging mobs burned churches and other Christian buildings, killing at least 38 people and leaving up to 50,000 more homeless. U.S. officials took note of the unrest and urged the Indian government to protect religious freedom throughout the country. By some accounts, the Hindu radicals were pursuing a political agenda; there was speculation that violent attacks on Orissa's Christian communities was part of an organized political project by Hindu nationalist parties. ${ }^{299}$ Communal strife continued throughout the remainder of the year at a lower level, and state-level officials may have failed to provide sufficient security for the Christian minority. For some, the violence provided "a window into India's hidden fragility, its sometimes dangerous political climate, and the fierce historical divisions buried in its vast diversity." 300 There continue to be small-scale attacks on and harassment of Christians and their places of worship in India (see also the "Religious Freedom" section below). ${ }^{301}$

\section{Nuclear Arms Control and Nonproliferation}

India exploded a "peaceful" nuclear device in 1974 and tested nuclear weapons again in 1998. The country has 60-100 nuclear warheads, according to public estimates, ${ }^{302}$ and continues to produce plutonium for weapons. ${ }^{303}$ New Delhi has stated that it will not engage in a nuclear arms race and needs only a "credible minimum deterrent," but India has never defined what it means by such a deterrent. Both the U.S.-India nuclear cooperation agreement and the associated 2008 Nuclear Suppliers Group decision described below have renewed New Delhi's access to the international uranium market. This access will result in more indigenous Indian uranium available for weapons because it will not be consumed by India's newly safeguarded reactors.

New Delhi has refused either to sign the nuclear Nonproliferation Treaty (NPT) or accept International Atomic Energy Agency (IAEA) safeguards on all of its nuclear material and facilities. ${ }^{304}$ The NPT states-parties adopted language following the 2010 NPT Review

\footnotetext{
298 “Indian Muslims Blamed for 'Saffron Terror' Want Justice,” BBC News, January 27, 2011; “'Swami’s Confession,” Frontline (Chennai), February 11, 2011.

${ }^{299}$ Prafulla Das, "Project Orissa," Frontline (Chennai), September 26, 2008.

300 "Christians Face Attacks in Eastern India," Associated Press, October 25, 2008.

${ }^{301}$ See the U.S. Commission on International Religious Freedom's 2011 annual report at http://www.uscirf.gov/images/ book\%20with\%20cover\%20for\%20web.pdf.

${ }^{302}$ Arms Control Association, "Nuclear Weapons: Who Has What at a Glance," available at http://www.armscontrol.org/factsheets/Nuclearweaponswhohaswhat; Robert S. Norris and Hans M. Kristensen, "Indian Nuclear Forces, 2010," Nuclear Notebook, Bulletin of the Atomic Scientists, September/October 2010; SIPRI yearbook, 2011.

${ }^{303}$ Global Fissile Material Report 2009: A Path to Nuclear Disarmament, International Panel on Fissile Materials, 2009, p.16.

${ }^{304}$ India, Israel, and Pakistan are the only countries which are not parties to the NPT. North Korea's state-party status is ambiguous.
} 
Conference, which ended on May 28, 2010, calling on non-signatories to accede to the treaty as "non-nuclear-weapon States ... promptly and without any conditions." U.N. Security Council Resolution 1172, adopted after New Delhi's 1998 nuclear tests, called on India to take a number of steps which it has not taken, such as acceding to the NPT, ratifying the Comprehensive Test Ban Treaty (CTBT), and refraining from developing nuclear-capable ballistic missiles.

Despite this resistance to international arms control and nonproliferation agreements, M.K. Narayanan, then-National Security Adviser to Prime Minister Singh, stated in December 2009 that "India has a long-standing commitment to global, non-discriminatory and verifiable nuclear disarmament." Indeed, New Delhi has issued proposals for achieving global nuclear disarmament. For example, a 2007 working paper to the Conference on Disarmament called for the "[n]egotiation of a Nuclear Weapons Convention prohibiting the development, production, stockpiling and use of nuclear weapons and on their destruction, leading to the global, nondiscriminatory and verifiable elimination of nuclear weapons with a specified timeframe." 305 Moreover, Singh stated during the April 2010 Nuclear Security Summit that New Delhi is ready to "participate in the negotiation of an internationally verifiable Fissile Material Cut-off Treaty." ${ }^{306}$ Additionally, India has, despite its refusal to sign the CTBT, committed itself to a voluntary unilateral moratorium on nuclear testing.

New Delhi also supported the joint statement adopted at the Nuclear Security Summit, which contained a pledge to improve nuclear security standards and share best practices with other countries. ${ }^{307}$ Indian Prime Minister Manmohan Singh announced April 13, 2010, that New Delhi had "decided to set up a 'Global Centre for Nuclear Energy Partnership' in India." Describing the center as "a state of the art facility based on international participation from the IAEA and other interested foreign partners," Singh stated that it would include a "School" dealing with nuclear security. The United States and India signed in November 2010 a Memorandum of Understanding (MOU) providing "a general framework for cooperative activities in working with" the center. There is no public evidence that India has since conducted nuclear security activities with the United States, but the two governments are to hold the first meeting regarding implementation of the MOU sometime in 2011, according to a July 19, 2011, joint statement.

An off-the-record May 2011 gathering of regional and nuclear proliferation experts in Washington, DC, found widespread agreement that Pakistan's current weapons proliferation activities are destabilizing, that India's potential adoption of an altered nuclear doctrine (to include a delivery triad and ballistic missile defense) could exacerbate instability, and that the U.S. government may in the near future confront new nonproliferation challenges in South Asia that could even supplant counterterrorism imperatives.

\footnotetext{
${ }^{305}$ India Working Paper "Nuclear Disarmament," CD/1816 February 20, 2007. Available at http://daccess-ddsny.un.org/doc/UNDOC/GEN/G07/604/46/PDF/G0760446.pdf?OpenElement

${ }^{306}$ Statement by the Prime Minister of India Dr. Manmohan Singh at the Nuclear Security Summit, April 13, 2010, at http://www.indianembassy.org/prdetail1501/statement-by-the-prime-minister-of-india-dr.-manmohan-singh-at-thenuclear-security-summit-.

${ }^{307}$ For more information on the summit, see CRS Report R41169, Securing Nuclear Materials: The 2010 Summit and Issues for Congress, by Mary Beth Nikitin.
} 


\section{U.S.-India Bilateral Issues}

\section{U.S.-India Economic and Trade Relations}

As one of India's leading trade and investment partners, the United States strongly supports New Delhi's continuing economic reform policies. A U.S.-India Trade Policy Forum was created in 2005 to expand bilateral economic engagement and provide a venue for discussing multilateral trade issues. According to U.S. trade statistics, U.S. exports to India in 2010 totaled $\$ 19.222$ billion and imports from India totaled $\$ 29.531$ billion, for a bilateral trade deficit of $\$ 10.309$ billion. ${ }^{308}$ With a total trade of $\$ 48.753$ billion, India was the $12^{\text {th }}$ largest trading partner for the United States in 2010.

The leading U.S. exports to India in 2010 were (in order):

- Natural or cultured pearls, precious or semi-precious stones, precious metals, metals clad with precious metal and articles thereof and imitation jewelry (chapter 71)— \$4.206 billion;

- nuclear reactors, boilers, machinery, and mechanical appliances, or parts thereof (chapter 84)— $\$ 2.607$ billion; and

- electrical machinery and equipment and parts thereof (chapter 85) - \$1.367 billion.

The top imports from India were (in order):

- Natural or cultured pearls, precious or semi-precious stones, precious metals, metals clad with precious metal and articles thereof and imitation jewelry (chapter 71) - $\$ 6.850$ billion;

- pharmaceutical products (chapter 30)— \$2.388 billion; and

- mineral fuels, mineral oils and products of their distillation (chapter 27) - \$2.324 billion.

The cross-trade in items under chapter 71 reflects a strong interrelationship for the industries in both nations. India is a major global supplier of precious gems and stones, whereas the United States is a major supplier of finished jewelry. ${ }^{309}$

In addition to their merchandise trade flows, India and the United States have significant service trade relations. In 2009 (latest available figures), U.S. private services exports to India totaled $\$ 9.940$ billion, and imports from India totaled $\$ 12.377$ billion. ${ }^{310}$ The leading U.S. service export to India was education ( $\$ 3.155$ billion), and the leading service import from India was "business, professional, and technical services" ( $\$ 8.920$ billion).

\footnotetext{
${ }^{308}$ Trade statistics from the U.S. International Trade Commission (USITC).

${ }^{309}$ For more information on bilateral trade in jewelry, see CRS Report RL34161, India-U.S. Economic and Trade Relations, by Michael F. Martin and K. Alan Kronstadt.

${ }^{310}$ Data from the U.S Bureau of Economic Analysis (BEA).
} 
Annual inward foreign direct investment (FDI) to India from all countries rose from about $\$ 100$ million in FY1990/91 to nearly $\$ 3$ billion in FY2000/01 and over $\$ 19$ billion in FY2010/11. The stock of U.S. FDI in India as of March 2011 stood at $\$ 9.4$ billion. According to the Indian Ministry of Commerce and Industry, about 7.5\% of FDI in India since 2000 has come from U.S. firms; in recent years, the major U.S.-based companies Microsoft, Dell, Oracle, and IBM have made multi-billion-dollar investments in India. Wisconsin-based Harley-Davidson recently opened a motorcycle manufacturing plant in India's northern Haryana state, its second outside the United States. Michigan-based Ford Motor Company has plans to expand its operation in India by investing \$1 billion in a new factory in Gujarat, its second production line in India. In 2011, Illinois-based Boeing, which sees no more important a potential customer in the world, projected that India will spend some $\$ 150$ billion on more than 1,300 new passenger airplanes over the next two decades. India is also among the fastest growing investors in the United States; the Administration reports that investment capital from India grew at an annualized rate of $53 \%$ over the past decade, reaching about $\$ 4.4$ billion in 2009. Among the most important investors has been India's Tata Group, which reportedly employs some 19,000 people in the United States. ${ }^{311}$

\section{U.S.-India Economic Issues and Engagement}

While bilateral relations are generally good, there are a number of economic and trade issues between India and the United States of varying degrees of importance. For the United States, the more pressing issues are intellectual property rights protection, trade in dual-use technology, access to selective Indian markets, and India's participation in the U.S. Generalized System of Preferences (GSP) program. For India, the key issues are negotiations of a bilateral investment treaty (BIT), U.S. restrictions on the trade in services (including the limited supply of H1-B visas), high-technology export controls, and the U.S. farm subsidy program.

Commerce Secretary Locke led a trade mission to New Delhi, Bangalore, and Mumbai in February 2011, accompanied by representatives of 24 U.S. companies, many of them seeking to strike weapons sales deals or capitalize on the 2008 U.S.-India civil nuclear agreement. In meetings with his Indian counterpart, Locke raised longstanding issues of friction, including market access barriers and intellectual property protection. Speaking at a Confederation of Indian Industry luncheon, the Secretary went into some detail on these and other issues, asserting that seizing the full potential of bilateral cooperation will require India to take further steps to open its economy by reducing an array of tariff and nontariff barriers, and lifting restrictions on foreign direct investment:

Ultimately, what America seeks is a level playing field for its companies, where the cost and quality of their products determines whether or not they win business. In seeking a level playing field, we are merely asking for the same treatment foreign companies and investors receive in America. ${ }^{312}$

Repeats of this message from the Administration have become both firmer and more common in 2011. In a major May speech on the future of U.S.-India relations, Assistant Secretary Blake said:

\footnotetext{
${ }^{311}$ See the Ministry's Department of Industrial Policy and Promotion data at http://www.dipp.nic.in/fdi_statistics/ india_fdi_index.htm; "US-India Economic and Trade Relationship: Indian Investment in the U.S.," White House press release, November 6, 2010.

${ }^{312}$ See the U.S. Embassy's February 7, 2011, press releases.
} 
[E]conomic impediments make it hard for American exporters to gain access to Indian markets, especially in agricultural goods. Restrictions in retail, insurance, defense, and other key areas have also limited the expansion of American firms, and the Indian firms with whom they seek to partner. To maintain this trajectory [of increased trade], we need to methodically address trade and investment barriers and foster market openings that position us to capitalize on this continued growth, and allow our private sectors to thrive. ${ }^{313}$

The outgoing U.S. Ambassador put it even more bluntly, saying, "India needs to be asking itself: Is it delivering on the global partnership? ... There's no doubt this needs to be a two-way street." ${ }^{314}$ Commerce Department officials and the White House Chief of Staff have more recently admonished New Delhi to move forward with economic reforms. Of particular recent concern to Secretary Locke and other U.S. officials is New Delhi's restrictions on imports of solar power technology. The central government plans to disburse some $\$ 20$ billion in subsidies to powerplant developers this decade, but is barring importation of foreign-made solar panels, making it difficult for U.S. firms to get a share of the market. ${ }^{315}$

In June 2011, Treasury Secretary Tim Geithner led the U.S. delegation at the second meeting of the U.S.-India Financial and Trade Partnership in Washington, DC, where he and his Indian counterpart, Finance Minister Pranab Mukherjee, agreed to further expand bilateral trade and investment links. While acknowledging that reducing barriers to investment was politically challenging for the Indian government, he reiterated the U.S. contention that easing such barriers would benefit both national economies and be an important step toward their "integration." 316

\section{Intellectual Property Rights Protection}

Inadequate intellectual property rights protection is a long-standing issue between the United States and India. India remained on the U.S. Special 301 "Priority Watch List" in 2011 for failing to provide an adequate level of IPR protection or enforcement, or market access for persons relying on intellectual property protection. ${ }^{317}$ The report recognized the introduction of a Copyright Amendment Bill as an improvement in the regulatory regime, but expressed concerns about its compliance with international standards. The United States also acknowledged India's progress on enforcement, but maintained that piracy and counterfeiting, including the counterfeiting of pharmaceuticals, remains widespread. India remains critical of U.S. efforts to pressure developing nations, including India, to adopt laws and regulations governing pharmaceuticals that are overly supportive of the major pharmaceutical companies and could potentially deny poorer nations of access to important medicines.

\footnotetext{
313 "The Current State of U.S.-India Cooperation and Prospects for the Future (As Prepared)" (speech transcript), Department of State release, May 13, 2011.

${ }^{314}$ Amb. Tim Roemer quoted in "U.S. Envoy Prods India on Reforms," Wall Street Journal, May 18, 2011.

315 “U.S. Concerned About India’s Barriers to Investment," Wall Street Journal, June 24, 2011; “India Solar Rules Burn U.S.," Wall Street Journal, February 8, 2011.

316 “U.S., India Pledge Cooperation on Market Access,” Reuters, June 28, 2011; Embassy of India press release, June 29, 2011.

${ }^{317}$ The International Intellectual Property Alliance (IIPA), a coalition of U.S. copyright-based industries, estimated U.S. losses of more than $\$ 1$ billion due to copyright piracy in India in 2009, with the great majority of this in the categories of business and entertainment software. The IIPA also noted inadequate coordination between national and local enforcement agencies. (see http://www.iipa.com/rbc/2011/2011SPEC301INDIA.pdf).
} 


\section{Trade in Dual-Use Technology}

The year 2003 saw the inaugural session of the U.S.-India High-Technology Cooperation Group (HTCG), a forum in which officials can discuss a wide range of issues relevant to creating the conditions for more robust bilateral high technology commerce. The $8^{\text {th }}$ HTCG meeting was held in New Delhi, India, on July 19, 2011, with discussion focusing on dual-use technology and ways to foster greater research and development cooperation. In 2007, India and the United States concluded a bilateral 123 Agreement on civil nuclear cooperation. While the accord addressed many concerns about India's nuclear program and trade in dual-use technology, there remain concerns in the United States about India's ability to prevent the distribution of potentially dangerous technology and equipment to undesirable recipients.

Since 1998, a number of Indian entities have been subjected to case-by-case licensing requirements and appear on the U.S. export control "Entity List" of foreign end users involved in weapons proliferation activities. In 2004, as part of NSSP implementation, the United States modified some export licensing policies and removed the Indian Space Research Organization (ISRO) headquarters from the Entity List. Further adjustments came in 2005 when six more subordinate entities were removed. In January 2011, Commerce's Bureau of Industry and Security removed several Indian space- and defense-related companies from the Entity List. ${ }^{318}$

\section{U.S Market Access in India}

The United States would like greater access to India's domestic markets, particularly for such products and services as agricultural goods, financial services, and retail distribution. India's extensive trade and investment barriers have been criticized by U.S. government officials and business leaders as an impediment to its own economic development, as well as to stronger U.S.India ties. The U.S. government maintains that India is using sanitary and phytosanitary (SPS) regulations to restrict the import of certain U.S. agricultural goods. India denies these claims, arguing that the U.S. farm subsidy program unfairly subsidies U.S. agricultural exports and greater market access would threaten the livelihood of many of India's farmers.

Multi-brand foreign retailers such as Wal-Mart and Target continue to be barred from the Indian market due to fears that India's small shops (there are as many as 12 million of them) would be overwhelmed by the competition. The U.S.-India Business Council is among those commercial groups contending that liberalization and greater international participation would benefit India by creating new and better employment opportunities, and by modernizing the country's supply chain management and distribution. ${ }^{319}$

\section{India's Participation in the GSP Program}

India is designated as a beneficiary developing country (BDC) in the U.S. GSP program since its inception in $1974 .{ }^{320}$ As such, a limited amount of Indian imports of selected goods can enter the

\footnotetext{
${ }^{318}$ Bureau of Industry and Security, "Commerce Takes Steps to Implement Export Control Initiatives to Facilitate High-Tech Trade with India," press release, January 24, 2011.

319 “Obama Aims to Deepen US Economic Ties With India, But What About Wal-Mart?," Christian Science Monitor, November 5, 2010.

${ }^{320}$ For more about India's participation in the U.S. GSP program, see CRS Report RL33663, Generalized System of Preferences: Background and Renewal Debate, by Vivian C. Jones.
} 
United States duty-free. Some in Congress believe that India is too developed to remain a GSP beneficiary, while others contend that India should be removed from the GSP program because of its stance on various issues related to the World Trade Organization's Doha Round negotiations. India was the third largest GSP beneficiary in 2010, after Angola and Thailand.

\section{Bilateral Investment Treaty}

India is pressing the United States to carry out negotiations of a bilateral investment treaty (BIT). A BIT is frequently seen as the first step in the possible progress towards a free trade agreement (FTA). In addition, a BIT between India and the United States might foster greater FDI flows between the two nations. Preliminary talks were held in 2009, and there has been only rhetorical progress on the issue since. The United States may be missing out on multiple business opportunities as India goes forward with comprehensive trade agreements that will lower tariffs on imports into India from countries such as Japan and Malaysia. Faster movement toward a U.S.-India BIT could improve prospects for American investors, as well as reassure those in Asia who question the U.S. commitment to a long-term economic role in the region. During a session of the U.S.-India Trade Policy Forum in Washington, DC, in June 2011, visiting Indian Commerce Minister Anand Sharma and U.S. Trade Representative Ron Kirk agreed to "fast-track technical negotiations for an early conclusion" of a BIT. ${ }^{321}$

\section{U.S. Restrictions on Trade in Services}

India would like to have greater access to U.S. services market, particularly the ability of Indian nationals to provide services in the United States. There are two aspects of this issue. First, via its various certification programs, the United States restricts the ability of many Indian professionals (such as accountants, medical doctors, and lawyers) from providing services in the United States. Second, the United States limits the number of people who can work in the country under its H1$\mathrm{B}$ visa program for certain high-skilled jobs. India would like the United States to increase or remove the limit on $\mathrm{H} 1-\mathrm{B}$ visas.

\section{U.S. Farm Subsidy Program}

India maintains that the U.S. farm subsidy program — worth an estimated $\$ 17.7$ billion per yearprovides U.S. agricultural exports with an unfair trade advantage. To the Indian government, the U.S. program poses a threat to millions of Indian farmers, hence it maintains restrictions on U.S. agricultural imports. In addition, India sees the U.S. reluctance to curtail or eliminate its farm subsidy program as a major roadblock in making progress in the Doha Round negotiations.

\section{Multilateral Trade Negotiations ${ }^{322}$}

In 2006, the World Trade Organization's "Doha Round" of multilateral trade negotiations were suspended due to disagreement among the WTO's six core group members-which include the

${ }^{321}$ Evan Feigenbaum, "Time for a US-India Investment Treaty" (op-ed), Economic Times (Delhi), May 2, 2011; Indian Embassy press release, June 22, 2011.

${ }^{322}$ See also CRS Report RL32060, World Trade Organization Negotiations: The Doha Development Agenda, by Ian F. Fergusson, and CRS Report RL33144, WTO Doha Round: The Agricultural Negotiations, by Charles E. Hanrahan and Randy Schnepf. 
United States and India - over methods to reduce trade-distorting domestic subsidies, eliminate export subsidies, and increase market access for agricultural products. The United States and other developed countries seek substantial tariff reductions in the developing world. India, like other members of the "G-20" group of developing states, has sought more market access for its goods and services in the developed countries, while claiming that developing countries should be given additional time to liberalize their own markets. In particular, India resists opening its markets to subsidized agricultural products from developed countries, claiming this would be detrimental to tens of millions of Indian farmers and lead to further depopulation of the countryside. According to Indian officials, the WTO's narrow focus on economic issues excludes political and social variables which are equally sensitive for New Delhi and which constrain the options available to the Indian government. They seek greater U.S. understanding of this dynamic. The Indian economy could benefit significantly from lowered farm subsidies in developed countries and expanded trade in services, but indigenous industries could also be harmed if New Delhi were to reduce tariffs that currently protect India's exporting sectors, especially in textiles and garments.

\section{Space Cooperation}

Bilateral space cooperation may be a particularly productive pursuit now that the U.S. Commerce Department has removed obstacles to trade with India's civil space agencies. The United States welcomes India's robust participation in multilateral fora such as the Committee on Earth Observation Satellites and the Group on Earth Observations, and has engaged in preliminary talks on human space flight cooperation. Earth observation cooperation benefits agricultural productivity through more accurate weather and climate forecasting. Some analysts view bilateral space cooperation as a particularly productive pursuit now that the U.S. Commerce Department has removed obstacles to trade with India's civil space agencies. However, India's space program suffered a major setback in late 2010 when the country's Geo-Synchronous Launch Vehicle (GSLV) went out of control 47 seconds after launch and was destroyed along with its telecommunications satellite payload. With a 50\% success rate, the GSLV may no longer be considered a viable option for many commercial satellite launches. ${ }^{323}$

\section{U.S.-India Civil Nuclear Cooperation ${ }^{324}$}

\section{Background}

India's status as a non-signatory to the 1968 Nuclear Nonproliferation Treaty (NPT) kept it from accessing most nuclear technology and fuels on the international market for more than three decades. New Delhi's 1974 "peaceful nuclear explosion" spurred the U.S.-led creation of the Nuclear Suppliers Group (NSG) — an international export control regime for nuclear-related trade - and Washington further tightened its own export laws with the Nuclear Nonproliferation Act of 1978 (P.L. 95-242). ${ }^{325}$ New Delhi has long railed at a "nuclear apartheid" created by an

\footnotetext{
${ }^{323}$ Rajeswari Pillai Rajagopalan, “US-India Strategic Dialogue: 'Sky’s No Limit' for Space,” Observer Research Foundation, July 18, 2011; "Space Cooperation" in "The U.S.-India Partnership: The Fact Sheets," White House release, November 8, 2010; "New Delhi, We Have a Problem: India's Space Woes," Time, December 29, 2010.

${ }^{324}$ See also CRS Report CRS Report RL33016, U.S. Nuclear Cooperation with India: Issues for Congress, by Paul K. Kerr.

${ }^{325}$ The Nuclear Suppliers Group is a voluntary nuclear export control regime consisting of 46 participating (continued...)
} 
apparent double standard inherent in the NPT, which, they maintain, has allowed certain states to deploy nuclear weapons legitimately while other states cannot. ${ }^{326}$ Senior Indian officials maintain the widely held Indian perspective that reaching a civil nuclear deal with the United States was crucial to the process of removing constraints placed on India by "an increasingly selective, rigorous, and continually expanding regime of technology denial," claiming that only by "turning the nuclear key" would India be able to open the door to global trade in dual use and other sophisticated technologies, including nuclear technologies. ${ }^{327}$

Differences over nuclear policy bedeviled U.S.-India ties for decades and—given New Delhi's lingering resentments - presented a serious psychological obstacle to more expansive bilateral relations. In a major policy shift, a July 2005 U.S.-India Joint Statement notably asserted that "as a responsible state with advanced nuclear technology, India should acquire the same benefits and advantages as other such states," and President Bush vowed to work on achieving "full civilian nuclear energy cooperation with India." ${ }^{328}$ As a reversal of three decades of U.S. nonproliferation policy, such proposed cooperation stirred controversy and required changes in both U.S. law and in NSG guidelines. India reciprocally agreed to take its own steps, including identifying and separating its civilian and military nuclear facilities in a phased manner and placing the former under International Atomic Energy Agency safeguards.

After extensive and difficult negotiations, U.S. legislation allowing the United States to conclude a peaceful nuclear cooperation agreement with India became law in December 2006 (P.L. 109401). President Bush signed P.L. 110-369, which approved the agreement, into law in October 2008. Secretary of State Condoleezza Rice and India's External Affairs Minister Pranab Mukherjee signed the agreement later that month and it entered into force in December 2008. Following an intense U.S. lobbying effort, the NSG decided in September 2008 to exempt India from some of its export requirements - a decision that enabled the government to conclude nuclear cooperation agreements with several countries. ${ }^{329}$

In the realm of geopolitics, much of the Bush Administration's argument for moving forward with the U.S.-India nuclear initiative appeared rooted in an anticipation/expectation that New Delhi would in coming years and decades make policy choices that are more congruent with U.S. regional and global interests (a desire for such congruence is, in fact, written into the enabling legislation, P.L. 109-401). Proponents have suggested that this U.S. "gesture" would have significant and lasting psychological and symbolic effects in addition to the material ones, and that Indian leaders require such a gesture in order to feel confident in the United States as a reliable partner on the world stage. Skeptics aver that the potential strategic benefits of the nuclear initiative have been over-sold. Indeed, centuries of Indian anti-colonial sentiments and oftentimes prickly, independent foreign policy choices are unlikely to be set aside in the short run,

\footnotetext{
(...continued)

governments.

${ }^{326}$ Under the NPT, the five nuclear-weapon states are China, France, Russia, the United Kingdom, and the United States. All other parties are non-nuclear-weapon states; currently, India cannot join the NPT as a nuclear-weapon state. The final document adopted after the 2000 NPT Review Conference stated that India's nuclear tests "do not in any way confer a nuclear-weapon-State status or any special status whatsoever."

${ }^{327}$ See, for example, a February 2008 speech by Indian Special Envoy and former Foreign Secretary Shyam Saran at http://www.ndtv.com/convergence/ndtv/popups/shyamsaran.pdf.

${ }^{328}$ See the statement text at http://meaindia.nic.in/mystart.php?id=53059889.

${ }^{329}$ See CRS Report RL33016, U.S. Nuclear Cooperation with India: Issues for Congress, by Paul K. Kerr.
} 
meaning that the anticipated geopolitical benefits of civil nuclear cooperation with India remain largely speculative and at least somewhat dependent upon unknowable global political developments. It is worth noting that, although proponents of the nuclear agreement argued that it would bring New Delhi into the "nonproliferation mainstream," India has not made any significant changes to its nuclear-weapons policies.

\section{Recent Developments}

U.S. companies have not yet started nuclear trade with India. Washington and New Delhi announced March 29, 2010, that they had concluded an agreement on a reprocessing facility in India; the two countries signed the agreement July 30, 2010. The arrangement, which the Administration had submitted to Congress on May 11, 2010, would not have taken effect if Congress had adopted a joint resolution of disapproval within 30 days of continuous session; Congress did not adopt such a resolution. New Delhi had reportedly insisted that India and the United States conclude the arrangement before New Delhi would sign contracts with U.S. nuclear firms. Despite the subsequent arrangement, U.S. firms may be reluctant to engage in nuclear trade with India if the government does not resolve concerns regarding its policies on liability for nuclear reactor operators and suppliers. ${ }^{330}$

India signed the Convention on Supplementary Compensation for Nuclear Damage (CSC), which has not yet entered into force, October 27, 2010. However, many observers have argued that India's Civil Liability for Nuclear Damage Bill, which both houses of India's parliament adopted in August 2010, is not consistent with the CSC, citing the provisions which make reactor suppliers, in addition to operators, liable for damages caused by a reactor accident. ${ }^{331}$ U.S. officials have argued that India's law should be consistent with the Convention. Assistant Secretary of State Robert Blake stated in a June 9, 2010, interview with India Abroad that the U.S. interest is to "ensure that the bill that ultimately is enacted is compliant" with the CSC. Although Under Secretary of State William Burns described New Delhi's signing of the CSC as a "very positive step" during an October 27 press briefing, he also indicated that India will need to take additional steps in order to resolve U.S. concerns regarding India's liability policies. Secretary of State Hillary Clinton indicated during a July 19, 2011, press conference that the United States wants India to ratify the CSC by the end of 2011, as well as adopt a liability regulatory regime that "fully conforms with the international requirements" under the CSC. India's then-Foreign Secretary Nirupama Rao stated in a July 29, 2011, interview that India would ratify the CSC "before the end of the year." She also explained that "the rules and regulations concerning the civil nuclear liability bill ... are in the process of being framed and in this process we are consulting with both the domestic companies and the foreign companies concerned." 332

Washington and New Delhi are also discussing necessary monitoring arrangements for U.S. nuclear exports. Section 104 (d)(5) of the Hyde Act requires the President to "ensure that all appropriate measures are taken to maintain accountability with respect to nuclear materials, equipment, and technology sold, leased, exported, or re-exported to India," including a "detailed system of reporting and accounting for technology transfers, including any retransfers in India,

\footnotetext{
330“'India Weighs Measure to Ease Nuclear Liability,” Wall Street Journal, October 10, 2010.

331 "India Risks Nuclear Isolation with Break From Chernobyl Accord,” Bloomberg, August 26, 2010; "India Liability Bill Seen Shaking Up Nuclear Trade, Liability Regime," Nucleonics Week, September 2, 2010.

332 "Interview of Foreign Secretary to Smt. Kalyani Shankar for All India Radio,” July 29, 2011.
} 
authorized by the Department of Energy pursuant to section 57 b. of the Atomic Energy Act.",333 India has provided retransfer assurances covering several state-owned entities, but has not yet provided them for private entities. ${ }^{334}$

\section{U.S.-India Security Cooperation}

Defense cooperation between the United States and India remains in relatively early stages of development (unlike U.S.-Pakistan military ties, which date back to the 1950s). Since late 2001, and despite a concurrent U.S. rapprochement with Pakistan, U.S.-India security cooperation has flourished; U.S. diplomats rate military cooperation among the most important aspects of transformed bilateral relations. The India-U.S. Defense Policy Group (DPG)—moribund after India's 1998 nuclear tests and ensuing U.S. sanctions - was revived in 2001 and meets annually. At the most recent session, in Washington, DC, in March 2011, senior U.S. State Department and Pentagon officials and their Indian counterparts reaffirmed the importance of and expressed satisfaction with ongoing bilateral defense cooperation, especially in the areas of joint military exercises and arms sales. The DPG operates four subgroups - a Military Cooperation Group, a Joint Technology Group, a Senior Technology Security Group, and a Defense Procurement and Production Group — which meet throughout the year. ${ }^{335}$

In June 2005, the United States and India signed a ten-year defense pact outlining planned collaboration in multilateral operations, expanded two-way defense trade, increasing opportunities for technology transfers and co-production, expanded collaboration related to missile defense, and establishment of a bilateral Defense Procurement and Production Group. The agreement may be the most ambitious such security pact ever engaged by New Delhi. A Maritime Security Cooperation Agreement, inked in 2006, commits both countries to "comprehensive cooperation" in protecting the free flow of commerce and addressing a wide array of threats to maritime security, including piracy and the illicit trafficking of weapons of mass destruction and related materials.

The United States views defense cooperation with India in the context of "common principles and shared national interests" such as defeating terrorism, preventing weapons proliferation, and maintaining regional stability. Senior officials in the Obama Administration's Pentagon have assured New Delhi that the United States is "fully committed to strengthening ties through the enhancement of our defense relationship." "336 In a report accompanying the Department of Defense Authorization Act for FY2012 (S. 1253, S.Rept. 112-26), the Senate Armed Services Committee, in expressing its belief that a deepened strategic partnership with India will be "critical" to the promotion of core mutual national interests in the $21^{\text {st }}$ century, would direct the

\footnotetext{
${ }^{333}$ Section 57 b. (2) of the AEA allows for limited forms of nuclear cooperation related to the "development or production of any special nuclear material outside of the United States" without a nuclear cooperation agreement if that activity has been authorized by the Secretary of Energy following a determination that it "will not be inimical to the interest of the United States." Agreements governing such cooperation are also known as "Section 810" agreements, after 10 Code of Federal Regulations Part 810.

${ }^{334}$ Yanmei Xie, "Clinton Urges India to Move Ahead on Nuclear Trade With US,” Nucleonics Week, July 21, 2011.

${ }^{335}$ See the Indian Embassy's March 9, 2011, press release.

${ }^{336}$ Under Secretary of Defense Michelle Flournoy quoted in "US and India Look to Enhance Defense Ties," Jane's Defense Weekly, July 9, 2010.
} 
Secretary of Defense to report to Congress a detailed plan to enhance U.S.-India security cooperation. ${ }^{337}$

Many analysts view increased U.S.-India security ties as providing an alleged "hedge" against or "counterbalance" to growing Chinese influence in Asia, though both Washington and New Delhi repeatedly downplay such probable motives. Still, while a congruence of U.S. and Indian national security objectives is unlikely in the foreseeable future, convergences are identified in areas such as shared values, the emergence of a new balance-of-power arrangement in the region, and on distinct challenges such as WMD proliferation, Islamist extremism, and energy security. There remain indications that the perceptions and expectations of top U.S. and Indian strategic planners are divergent on several key issues, perhaps especially on the role of Pakistan and policies toward the ongoing Afghan insurgency, as well as on India's relations with Iran and repressive governments in places such as Burma and Sudan.

\section{Intelligence and Counterterrorism}

One facet of the emerging "strategic partnership" between the United States and India is greatly increased intelligence and counterterrorism cooperation. In 2000, the two governments established a U.S.-India Joint Working Group on Counterterrorism to coordinate bilateral efforts in this realm. In 2002, India and the United States launched the Indo-U.S. Cyber Security Forum to safeguard critical infrastructures from cyber attack. The 2005 "New Framework for the U.S.India Defense Relationship" listed "defeating terrorism and violent religious extremism" as one of four key shared security interests, and it called for a bolstering of mutual defense capabilities required for such a goal. ${ }^{338}$ A bilateral Counterterrorism Cooperation Initiative was formally launched in July $2010 .^{339}$

Counterterrorism cooperation is described by the Administration as a pillar of the bilateral relationship. Programs include exchanges of law enforcement best practices, reciprocal visits of senior-level officials, joint military training exercises, and joint approaches in relevant international fora. The FBI's Quantico laboratory has hosted visits by senior Indian forensics experts and the agency regularly shares best-practices with senior Indian law enforcement officials. The State Department's Anti-Terrorism Assistance program has conducted scores of training courses for more than 1,600 Indian law enforcement officials. ${ }^{340}$

\footnotetext{
${ }^{337}$ The report would include, inter alia, a detailed assessment of current U.S.-India security cooperation, and a fiveyear plan to enhance such cooperation in the areas of bilateral and multilateral military exercises, defense trade and support for India's military modernization, and cooperation in disaster response, humanitarian assistance, counterproliferation, counterpiracy, counterterrorism, homeland security and coastal defense, and the maintenance of secure sea lines of communication.

${ }^{338}$ See http://www.indianembassy.org/press_release/2005/June/31.htm.

${ }^{339}$ The initiative, inter alia, provides for strengthening capabilities to effectively combat terrorism; promotion of exchanges regarding modernization of techniques; sharing of best practices on issues of mutual interest; development of investigative skills; promotion of cooperation between forensic science laboratories; establishment of procedures to provide mutual investigative assistance; enhancing capabilities to act against money laundering, counterfeit currency and financing of terrorism; exchanging best practices on mass transit and rail security; increasing exchanges between Coast Guards and Navy on maritime security; exchanging experience and expertise on port and border security; enhancing liaison and training between specialist Counter Terrorism Units including National Security Guard with their US counterparts (see http://www.indianembassy.org/prdetail1560/-india-us-sign-counter-terrorism-cooperationinitiative-).

${ }^{340}$ See "Counterterrorism Cooperation" in "The U.S.-India Partnership: The Fact Sheets," White House release, November 8, 2010. In April 2011, the city of Los Angeles hosted a U.S.-India Counterterrorism Seminar jointly (continued...)
} 
CIA and FBI personnel have worked in India to investigate terrorist attacks, including a major 2006 bombing in Mumbai, as well as the 2008 attack on the same city (FBI forensics experts provided testimony to the Indian court trying the sole surviving gunmen in the latter attack). In June 2010, the Indian government was granted access to David Headley, an American national who has confessed to participating in planning the November 2008 Mumbai assault. Then-U.S. Ambassador to India Tim Roemer identified the development as "historic in the nature of security cooperation" and expressed optimism about multiple U.S.-India partnerships in this area, including cooperation on launching a National Counterterrorism Center in India modeled on that in the United States. ${ }^{341}$ Yet lingering and significant distrust of the United States - and its close relationship with Pakistan's military and intelligence services - became evident after it was learned that U.S. officials had received prior warnings about LeT intentions to attack Mumbai from Coleman's former wives. U.S. officials deny that any useful intelligence information had been withheld from India, but some observers remained skeptical. ${ }^{342}$

Homeland Security Secretary Janet Napolitano was in New Delhi and Mumbai in May 2011, where she meet with Indian officials and representatives of private industry to promote counterterrorism and law enforcement cooperation. Under the rubric of the bilateral Strategic Dialogue, a U.S.-India Homeland Security dialogue was established, with Indian Home Minister Chidambaram as co-chair, wherein agency-to-agency engagements are being fostered on a wide array of law enforcement issues, including counternarcotics counterfeit currency, illicit financing and transnational crime, infrastructure security, transportation and trade, coastal security, and large-city policing. ${ }^{343}$

\section{Defense Cooperation and Trade}

\section{Combined Military Exercises}

Since early 2002, the United States and India have held a series of unprecedented and increasingly substantive combined exercises involving all military services. Such military-tomilitary relations have been key aspect of U.S.-India relations in recent years - India now conducts more exercises and personnel exchanges with the United States than with any other country. ${ }^{344}$ These include "Cope India" air exercises, ${ }^{345}$ joint Special Forces training ${ }^{346}$ and major annual "Malabar" joint naval exercises are held off the Indian coast. ${ }^{347}$ U.S. and Indian officials

\footnotetext{
(...continued)

sponsored by the U.S. Federal Bureau of Investigation and the Indian Home Ministry. Senior law enforcement officials from both countries, including 39 Indian police executives from 29 state and federal agencies across India, met to discuss such topics as crisis response, forensics, and megacity policing (U.S. Embassy press release, April 25, 2011).

${ }^{341}$ See the Ambassador's June 10, 2010, statement at http://newdelhi.usembassy.gov/pr061110.html.

342 “U.S. Didn’t Warn India Despite 'Information \& Concerns,” Hindu (Chennai), October 20, 2010.

${ }^{343}$ U.S. Embassy press release, May 24, 2011; Indian External Affairs Ministry release, May 27, 2011.

${ }^{344}$ See "Defense Cooperation" in "The U.S.-India Partnership: The Fact Sheets," White House release, November 8, 2010.

${ }^{345}$ In 2004, mock air combat saw Indian pilots in late-model Russian-built fighters hold off American pilots flying older F-15Cs, and Indian successes were repeated versus U.S. F-16s in 2005.

${ }^{346}$ U.S. and Indian special forces soldiers have held at least seven "Vajra Prahar" joint exercises, and hundreds of U.S. Special Forces soldiers have attended India's Counter-Insurgency Jungle Warfare School.

${ }^{347}$ In 2008, the aircraft carrier USS Ronald Reagan, the nuclear submarine USS Springfield, and five other major American naval vessels joined Indian navy ships in the Arabian Sea. Unlike in previous years, the 2008 Malabar (continued...)
} 
tout ongoing joint maneuvers as improving interoperability and as evidence of an overall deepening of the bilateral defense relationship. Countries such as China and Pakistan are acutely interested in the progress of such relations, seeing them as the potential seeds of a more formal defense alliance.

\section{Defense Trade}

Along with increasing military-to-military ties, the issue of U.S. arms sales to India has taken a higher profile. New Delhi is undertaking a major military modernization program, potentially spending \$100 billion over the next decade to update its mostly Soviet-era arsenal. U.S. weapons makers are eager to gain a slice of this lucrative pie, and American security companies also see in India a potentially also huge new market for sophisticated equipment such as surveillance and detection systems. Some analysts suggest that increased defense trade could be a means of reviving what are perceived as stagnating U.S.-India relations. ${ }^{348}$ Yet many Indians continue to be wary of closer defense ties with the United States and are concerned that these could lead to future strings, such as conditionality and/or cutoffs, and perhaps constrain New Delhi's foreign policy freedom. In an unusually open expression of frustration with the United States in this realm, India's Army Chief in May 2010 informed his Defense Ministry that the U.S. Foreign Military Sales program had proven troublesome for India. ${ }^{349}$ Nevertheless, the value of new and unprecedented major defense sales to India has continued to grow, with the United States now offering to sell India some of its most sophisticated military hardware. ${ }^{350}$

The first-ever major U.S. arms sale to India came in 2002, when the Pentagon negotiated delivery of 12 counter-battery radar sets (or "Firefinder" radars) worth a total of $\$ 190$ million. In 2006, Congress authorized and New Delhi approved the \$44 million purchase of the USS Trenton, a decommissioned American amphibious transport dock. The ship, which became the secondlargest in the Indian navy when it was commissioned as the INS Jalashwa in 2007, set sail for India carrying six surplus Sikorsky UH-3H Sea King helicopters purchased for another \$39 million. The Security Cooperation Act of 2010 (P.L. 111-266) authorized the President to transfer to India two Osprey-class coastal minehunter ships as Excess Defense Articles. In 2008, Washington and New Delhi finalized a deal to send to India six C-130J Hercules military transport aircraft (along with related equipment, training, and services). The deal, which represented the largest-ever U.S. defense sale to India to date, is worth nearly $\$ 1$ billion to the manufacturer, Maryland-based Lockheed Martin (the C-130Js, configured to support Indian special operations requirements, were delivered in December 2010). In 2009, New Delhi signed a \$2.1 billion deal to purchase eight P-8I maritime surveillance aircraft from Illinois-based Boeing.

\footnotetext{
(...continued)

exercises were bilateral and did not include warships from any third country. During the previous exercise, India hosted a total of 27 warships from five countries - including the United States, Japan, Australia, and Singapore-for maneuvers in the Bay of Bengal. It was the first time such exercises were conducted off India's east coast.

${ }^{348}$ Sunil Dasgupta and Stephen Cohen, “Arms Sales for India: How Military Trade Could Energize U.S.-India Relations," Foreign Affairs, March 2011.

349 “Army Chief Warns Against Govt-to-Govt Deals With US," Times of India (Delhi), May 25, 2010.

${ }^{350}$ For example, in a June 2011 report (S.Rept. 112-26), the Senate Armed Services Committee raised the idea of potential future sales to India of the F-35 Joint Strike Fighter, as well as a potential U.S.-India co-development partnership on other weapons systems, perhaps to include the anticipated program to replace the U.S. Air Force's T-38 trainer jet.
} 
These aircraft, slated for delivery in 2013, also provide anti-submarine warfare capabilities, and their sale set a new record as the largest-ever U.S. arms transfer to India.

In 2010, the Pentagon notified Congress of a potential sale to India of ten C-17 Globemaster III military transport aircraft (with training equipment, spare parts, and other support). Yet another new record sale was realized when, in June 2011, New Delhi formally approved the $\$ 4.1$ billion purchase, the largest-ever Indian defense contract with a U.S. company. Washington welcomed the sale as both advancing the U.S.-India partnership and in sustaining some 23,000 American jobs in 44 states. ${ }^{351}$ Other potential upcoming sales include

- 22 Lockheed Martin AH-64D Apache attack helicopters, along with accompanying General Electric engines, and radars, missiles, training, and other support that could be worth an estimated $\$ 1.4$ billion;

- 145 lightweight $155 \mathrm{~mm}$ M777 towed howitzers with laser targeting systems (worth $\$ 647$ million); and

- 26 Harpoon anti-ship missiles for $\$ 200$ million and $32 \mathrm{Mk}-54$ torpedoes for $\$ 86$ million - both weapons intended for use on the Indian Navy's newly-purchased P-8I Neptune maritime patrol aircraft.

Yet by far the most lucrative hoped-for sale would have served India's quest for 126 new medium, multi-role combat aircraft (MMRCA) in a deal that could be worth some \$11 billion. Lockheed Martin's F-16 and Boeing's F/A-18 were competing with aircraft built in Russia, France, Sweden, and by a European consortium. Hopes of an American firm landing the MMCA deal received a boost in 2009 when General Electric won in its bid to provide India with 99 jet engines for its Tejas light combat aircraft for some \$800 million, but in 2011 New Delhi announced that it would not look to American firms for this larger sale (see below).

\section{Outstanding Defense Cooperation Agreements}

Some Indian officials express concern that the United States is a "fickle" partner that may not always be relied upon to provide the reciprocity, sensitivity, and high-technology transfers sought by New Delhi, and that may act intrusively. This has contributed to New Delhi's years-long political resistance to sign several defense cooperation accords, including the Communications Interoperability and Security Memorandum of Agreement (CISMoA), the Basic Exchange and Cooperation Agreement for Geospatial Cooperation (BECA), and the Logistics Support Agreement (LSA). ${ }^{352}$ U.S. law requires that certain sensitive defense technologies can only be transferred to recipient countries that have signed the CISMoA and/or the BECA. All three outstanding accords have been opposed by some influential Indian politicians for their "intrusive" nature, and the issue was not taken up at the July 2011 Strategic Dialogue talks. ${ }^{353}$

\footnotetext{
${ }^{351}$ U.S. Embassy press release, June 7, 2011.

352 The CISMoA requires purchasers of U.S. defense equipment to ensure that equipment supplied to India is compatible with other American systems. The BECA provides for mutual logistical support and enables exchanges of communications and related equipment. The LSA permits armed forces of both countries to enjoy reciprocal use of facilities for maintenance, servicing, communications, refueling, and medical care. New Delhi is wary of LSA provisions, which some there believe could lead to India's being caught up in U.S. regional military operations ("US and India Urged to Complete Defense Cooperation Deals," Jane's Defence Industry, June 2, 2010).

353 "India Averse to Inking Military Pacts With U.S.," Hindu (Chennai). June 23, 2011; "CISMOA, LSA Not on Table of Indo-US Strategic Dialogue,” Press Trust of India, July 15, 2011.
} 
New Delhi did in 2009 sign on to an End User Monitoring Agreement (EUMA) after two years of protracted negotiations, but only after receiving the concession that the time and location of equipment verification would be determined by Indian officials. Then-Secretary of Defense Robert Gates, on a visit to New Delhi in 2010, stated that not getting the outstanding agreements signed "is an obstacle to Indian access to the very highest level of technology." 354 Despite U.S. claims that India's military capabilities are hampered by lack of access to U.S. equipment and technologies, senior Indian military officers have reported to their government that the absence of these agreements makes no substantial difference in their operational abilities. ${ }^{355}$

\section{MMRCA “Deselection"}

By the turn of the new century, New Delhi began to address the need to replace their air force's large and aging fleet of Russian-built MiG-21 combat aircraft, which were crashing regularly and became known to some Indian pilots as "flying coffins." ${ }^{\text {"356 }}$ Refurbishment was deemed impractical, and no indigenously-built replacement could be online for up to two decades so, in 2004, the government issued formal Requests For Information (RFIs) on potentially purchasing 126 new aircraft from one of four vendors: Lockheed Martin (F-16IN), France's Dassault (Rafale), Sweden's Saab (Gripen JAS-39), and Russia's Mikoyan (MiG-35). Soon after, Boeing (F/A-18E/F) and a European consortium (Eurofighter Typhoon) joined in the bidding. ${ }^{357}$

In April 2011, seven years after the first RFIs were issued, New Delhi announced that it had narrowed the list of competitors to two finalists: the French Rafale and the Eurofighter. The government described the decision as having been wholly rooted in technical assessments of the contending aircraft. These assessments determined that the Rafale and the Typhoon were best suited to the needs of their air forces. Assistant Secretary of State Blake expressed Washington's obvious disappointment, while also stressing that the United States will remain committed to the bilateral defense partnership - he contended that India had "shown confidence in American products" such as C-130J, C-17, and P-8 military aircraft - as well as to the greater strategic partnership. Blake later said that choosing one of the American-made platforms would have "provided a ladder to even higher levels of U.S.-India technology transfers" and it was "a source of puzzlement" that the Indian Air Force deselected them. ${ }^{358}$ New Delhi's decision elicited much criticism both from U.S.-based analysts as well as some Indian strategic thinkers, and sparked some debate over the "real" reasons for what seemed a major geostrategic choice.

Some commentators considered the Indian decision short-sighted and potentially damaging to the greater U.S.-India partnership. From this perspective, political and geostrategic considerations were given short-shrift or even ignored in New Delhi's apparently narrow focus on purely

\footnotetext{
354 “Gates Uses India Visit to Push for Defense Technology Accords,” Bloomberg.com, January 19, 2010.

355 “Absence of Military Pacts With U.S. Will Not Impact Capability: IAF Chief," Hindu (Chennai), October 16, 2010.

${ }^{356}$ In mid-2011, India's defense minister formally announced that all MiG-21s would be phased out by 2017,53 years after their first induction into service. During that time, India's air force inducted 946 of the aircraft, 476 of which have been lost to accidents ("India to Phase Out Mig-21s by 2017," Jane's Defense Weekly, August 10, 2011).

${ }^{357}$ Lockheed's pitch reportedly included offering a "super-cruise" version of the F-16 that saves large amounts of fuel by achieving supersonic speeds without the use of afterburners. Boeing, for its part, sought to establish multiple joint ventures that could better position the company to become India's preferred aerospace and defense partner ("US Contenders Enhance Their MRCA Offerings to India," Jane's Defense Weekly, January 30, 2008; "Boeing Keen to Develop India's Aerospace Industry," Reuters, July 16, 2008).

${ }^{358}$ Department of State release, April 29, 2011; "The Current State of U.S.-India Cooperation and Prospects for the Future (As Prepared)" (speech transcript), Department of State release, May 13, 2011.
} 
technical variables. The decision may not have been the great surprise that was perceived by some in Washington: Indian skepticism about U.S. reliability as an arms supplier is longstanding, and Washington's close defense relationship with Islamabad over the past decade has added to New Delhi's doubts. ${ }^{359}$

Indeed, many analysts sought to explain the decision by pointing to Indian concerns about U.S. reliability and Indian annoyance with U.S. arms supplies to Pakistan, with some also viewing the Europeans as being more willing than the Americans to transfer technologies desired by India. Supply reliability may have played a central role in what may have been a largely political decision. ${ }^{360} \mathrm{~A}$ few even suspected that deselecting the U.S.-built planes was an indirect statement that New Delhi did not seek full alignment with the United States. When viewed in light of serious obstacles to implementing bilateral civil nuclear commerce, and New Delhi's UNSC abstention on Libya and tepid support for Burmese democratization, the MMRCA decision was for some observers a (troubling) signal that Indian decision makers are uncomfortable with developing closer ties with the United States. ${ }^{361}$

Others rejected these arguments as unreasonable, given that most major powers seek to diversify their strategic relationships, the United States among them. For these commentators, the overarching relationship was not diminished by this one development and does best when a transactional approach is avoided. ${ }^{362}$ The judgment here is that there was no "strategic rebuff" of the United States, and Indian doubts about American reliability in arms trade is much diminished in recent years (U.S. firms have won numerous other Indian defense contracts). In the words of one close observer, "[T] he current threats to the burgeoning defense partnership derive less from abortive military sales and more from a lack of vision, focus, and determination to create the strategic affiliation that serves common interests. ${ }^{363}$ Moreover, it does appear that the Indian procurement process worked exactly as it was supposed to- divorced from political considerations - and that corruption scandals in New Delhi and the ruling coalition's recent travails made strategic factors even more unlikely to have played a role. ${ }^{364}$

\section{Human Rights Concerns}

Many of India's more than one billion citizens suffer from oftentimes serious human rights abuses. Some analysts are concerned that, as Washington pursues a new "strategic partnership" with New Delhi, U.S. government attention to such abuses has waned. In a notable shift, the State

\footnotetext{
${ }^{359}$ Leaked U.S. diplomatic cables reportedly showed that senior U.S. officials had for some time been aware that, given these circumstances, major arms sales such as that for the MMRCA could prove difficult to secure ("U.S. Long Feared India Arms-Sale Snag, Cable Shows," Reuters, April 29, 2011).

${ }^{360}$ See, for example, “A Way Forward in U.S.-India Defense Cooperation,” National Bureau of Asian Research, July 2011; Praveen Swami, "Why the Critics of India's Combat Jet Deal Are Wrong” (op-ed), Hindu (Chennai), May 2, 2011.

${ }^{361}$ See, for example, Rajesh Rajagopalan, "The US-India Strategic Partnership and the MMRCA Deal," Institute for Defense Studies and Analysis (New Delhi), May 6, 2011; Sumit Ganguly, "Not Squaring Up With Washington" (oped) Asian Age (Mumbai), June 15, 2011; Christophe Jaffrelot, "India Keeps Abstaining, But Abstention Cannot Be a Policy," Caravan (New Delhi), August 2011.

${ }^{362}$ S. Amer Latif and Karl Inderfurth, "U.S., India: Take a Long View of Relations" (op-ed), Defense News, May 2, 2011.

${ }^{363}$ Ashley Tellis, "Decoding India’s MMRCA Decision,” Force (Noida), June 2011.

${ }^{364}$ Ashley Tellis, "Decoding India's MMRCA Decision," Force (Noida), June 2011; author interviews with Indian diplomats, June 30, 2011, and August 25, 2011.
} 
Department's most recent Country Report on Human Rights Practices (released April 2011) does not include what had been regular overarching statements in previous reports about the Indian government's general respect for the rights of its citizens, nor does its introductory section make note of Indian government efforts or improvements in certain areas. Instead, the report moves quickly to a listing of India's "major human rights problems," including

reported extrajudicial killings of persons in custody, killings of protesters, and torture and rape by police and other security forces. Investigations into individual abuses and legal punishment for perpetrators occurred, but for many abuses, a lack of accountability due to weak law enforcement, a lack of trained police, and an overburdened court system created an atmosphere of impunity; lengthy court backlogs prolong the latter. Poor prison conditions and lengthy detentions were significant problems. Unlike in previous years (2008 and 2009), there were no instances of officials using antiterrorism legislation to justify excessive use of force; however, indiscriminate use of force by Border Security Forces was a problem. Corruption existed at all levels of government and police. There were reports of delays in obtaining legal redress for past attacks against minorities. The law in some states restricted religious conversion, but there were no reports of convictions under these restrictions. Violence associated with caste bias occurred. Domestic violence, child marriage, bonded labor, dowry-related deaths, honor crimes, and female feticide remained serious problems.

Separatist insurgents and terrorists in Jammu and Kashmir, the Northeastern States, and the Naxalite belt committed numerous serious abuses, including killing armed forces personnel, police, government officials, and civilians. Insurgents engaged in widespread torture, rape, beheadings, kidnapping, and extortion. The number of incidents, however, declined compared with the previous year. ${ }^{365}$

International human rights groups echo many of these findings. According to the 2011 World Report of Human Rights Watch,

Authorities made little progress [in 2010] in reforming the police; improving healthcare, education, and food security for millions still struggling for subsistence; ending discrimination against Dalits ("untouchables"), tribal groups, and religious minorities; and protecting the rights of women and children. ${ }^{366}$

Constraints on religious freedom are another matter of concern; India's Muslim and Christian minorities continue to face sometimes violent persecution. Moreover, rampant caste-based discrimination is identified as a major societal problem, as are female infanticide and feticide. "Honor killings" of couples accused of violating Hindu marriage traditions may be on the rise. ${ }^{367}$ The State Department's Bureau of Democracy, Human Rights, and Labor has in the past claimed that India's human right abuses "are generated by a traditionally hierarchical social structure, deeply rooted tensions among the country's many ethnic and religious communities, violent secessionist movements and the authorities' attempts to repress them, and deficient police methods and training." 368

\footnotetext{
${ }^{365}$ See http://www.state.gov/documents/organization/160058.pdf.

${ }^{366}$ See http://www.hrw.org/en/world-report-2011/india. See also the 2010 Amnesty International report at http://www.amnesty.org/en/region/india/report-2010.

367 “In India, Castes, Honor, and Killings Intertwine,” New York Times, July 9, 2010.

${ }^{368}$ U.S. Department of State, Supporting Human Rights and Democracy: The U.S. Record 2002-2003.
} 
Government treatment of actual or suspected militants and terrorists can be severe and potentially unlawful. India's 1958 Armed Forces Special Powers Act, which gives security forces wide leeway to act with impunity in conflict zones, has been called a facilitator of grave human rights abuses in several Indian states. Visits by representatives of the International Committee of the Red Cross in 2002-2004 reportedly revealed evidence of widespread torture by security forces in Kashmir. Such evidence was presented to U.S. officials, according to press reports about leaked diplomatic cables. A senior Indian police official in Kashmir called the allegations "baseless propaganda." A 2010 report by the Delhi-based Asian Center for Human Rights found that the incidence of torture and prison custody deaths in India is on the rise, and it chastised the current New Delhi government for failing to address these problems through legislative changes. After examining India's nonconflict areas, Human Rights Watch issued a 2011 report detailing what it calls India's "numerous, serious human rights violations" in the treatment of terrorism suspects detained following attacks, saying the "abuses are both unlawful under Indian and international law and counterproductive in the fight against terrorism." "369

Indian authorities have brought and threatened to bring sedition charges against prominent social activists. According to watchdog groups, India's colonial-era sedition law has been used to intimidate peaceful political dissenters in cases involving activists such as Dr. Binayak Sen and Arundhati Roy. Human Rights Watch repeatedly has called for the law's repeal. Sen, who spent in a total of 28 months in what he described as horrific prison conditions, later accused the government of using the sedition laws "to silence voices of dissent.",370

\section{Religious Freedom}

An officially secular nation, India has a long tradition of religious tolerance (with periodic lapses), which is protected under its constitution. The population includes a Hindu majority of $82 \%$ as well as a large Muslim minority of some 150 million (14\%). Christians, Sikhs, Buddhists, Jains, and others total less than $4 \%$. Although freedom of religion is protected by the Indian government, human rights groups have noted that India's religious tolerance is susceptible to attack by religious extremists. In its annual report on international religious freedom released in November 2010, the State Department contended that the New Delhi government

generally respected, provided incentives for, and intervened to protect religious freedom; however, some state and local governments imposed limits on this freedom. There was no change in the status of respect for religious freedom by the government during the reporting period. The national government, led by the United Progressive Alliance (UPA), continued to implement an inclusive and secular platform that included respect for the right to religious freedom. Despite the national government's rejection of Hindutva (Hindu nationalism), a few state and local governments continued to be influenced by Hindutva.... The law generally provided remedy for violations of religious freedom, however, due to a lack of

\footnotetext{
369 “Wikileaks: India 'Tortured' Kashmir Prisoners,” BBC News, December 17, 2010; Asian Center for Human Rights, “Torture in India 2010," April 2010; “The 'Anti-Nationals': Arbitrary Detention and Torture of Terrorism Suspects in India," Human Rights Watch, February 2011.

${ }^{370}$ In December 2010, Sen was sentenced to life imprisonment under the sedition law for criticizing the Chhattisgarh government's anti-Maoist policies. Roy was threatened with sedition charges following an October 2010 speech in which she voiced support for (nonviolent) Kashmiri separatism (see Human Rights Watch, "India: Repeal Sedition Law," January 5, 2011; Amnesty International, "Indian Doctor Binyak Sen's Conviction and Life Sentence Mock Justice," December 25, 2010). Sen quoted in “Activist Binyak Sen Attacks Sedition Laws," BBC News, April 28, 2011 , and "'It Was the Darkest Phase of My Life"” (interview), India Today (Delhi), July 4, 2011.
} 
sufficient trained police and corruption, the law was not always enforced rigorously or effectively in some cases pertaining to religiously oriented violence. ${ }^{371}$

A May 2011 report of the U.S. Commission on International Religious Freedom found that "India's progress in protecting and promoting religious freedom during the past year continued to be mixed" and that "justice for victims of communal violence ... remains slow and often ineffective." While noting the Indian government's creation of some structures to address past problems of communal violence, and recognizing positive steps taken by the central and state governments to improve religious freedom, the Commission again placed India on a "Watch List" of countries where it believes violations of religious freedom require very close attention. It urged the U.S. government to encourage and assist New Delhi in being more vigorous and effective in efforts to better protect religious freedom in India, including those aimed at halting violent attacks on religious minorities, undertaking more timely investigations and prosecutions of those alleged to have perpetrated such violence, among others. ${ }^{372}$

\section{Caste-Based Discrimination}

The millennia-old Hindu caste system reflects Indian occupational and socially defined hierarchies. Sanskrit sources refer to four social categories: priests (Brahmin), warriors (Kshatriya), traders (Vayisha) and farmers (Shudra). Tribals and lower castes were long known as "untouchables" - a term now officially banned but still widely used — or Dalits. ${ }^{373}$ Although these categories are understood throughout India, they describe reality only in the most general terms. National-level legislation exists to protect India's lower castes, yet, according to the U.S. State Department, "The Scheduled Castes and Scheduled Tribes (Prevention of Atrocities) Act lists offenses against disadvantaged persons and prescribes stiff penalties for offenders; however, this act had only a modest effect in curbing abuse and there were very few convictions." ${ }^{374}$ In the $110^{\text {th }}$ Congress, H.Con.Res. 139, expressing the sense of Congress that the United States should address the ongoing problem of untouchability in India, was passed by the full House, but was not considered by the Senate.

\section{Human Trafficking}

The State Department's latest annual report on trafficking in persons (issued June 2011) again said, "India is a source, destination, and transit country for men, women, and children subjected to forced labor and sex trafficking.... The Government of India does not fully comply with the minimum standards for the elimination of trafficking; however, it is making significant efforts to do so." Moreover, in noting the Indian Home Ministry's more focused efforts and the government's ratification a relevant U.N. Protocol in May, India's designation as a "Tier 2 Watch List" country, which it had held since 2004, was upgraded to "Tier 2," the second highest of four designations. Still, State criticized law enforcement efforts against bonded labor as remaining "inadequate," and said the complicity of public officials in human trafficking "remained a serious problem" and "impeded progress. ${ }^{375}$

\footnotetext{
${ }^{371}$ See http://www.state.gov/g/drl/rls/irf/2010/148792.htm.

${ }^{372}$ See http://www.uscirf.gov/reports-and-briefs/annual-report.html.

${ }^{373}$ See http://www.state.gov/r/pa/ei/bgn/3454.htm.

${ }^{374}$ See http://www.state.gov/g/drl/rls/hrrpt/2006/78871.htm.

${ }^{375}$ See http://www.state.gov/g/tip/rls/tiprpt/2011/164232.htm.
} 


\section{Female Infanticide and Feticide}

Given traditional societal discrimination against females, uneven female-to-male ratios are a matter of growing concern for India. The incidence of female infanticide and gender-selective abortions is identified as a serious human rights problem in India. The diffusion of enabling medical technology and the existence of unethical doctors have made sex-selective abortions more common there. Prime Minister Singh has called female feticide a "national shame" and said the government has a responsibility to curtail the widespread practice. The country's 2001 census found only 927 girls aged 0-6 for every 1,000 boys nationwide. Wealthier states, such as Delhi, Punjab, and Gujarat, have the lowest ratios (Punjab's was the lowest at 798). ${ }^{376}$ A 2006 study published in the British medical journal Lancet estimated that up to 10 million Indian females are "missing" due to sex-selective abortions and infanticide over the past two decades, and that some 500,000 girls are being "lost" annually. ${ }^{377}$ In subsequent years, the incidence of such practices only appears to be increasing. ${ }^{378}$ The most recent U.S. State Department Country Report on Human Rights for India (released April 2011), identified Punjab and Haryana as states in which female feticide was an especially "serious problem," and noted reports of relatives "forcing" women to engage in female feticide. ${ }^{379}$ A June 2011 survey of gender experts ranked India as the world's fourth most dangerous country for women, citing high rates of female feticide, infanticide, and human trafficking (neighboring Pakistan was ranked third). ${ }^{380}$

\section{U.S. Foreign Assistance}

A total of more than $\$ 15.9$ billion in direct U.S. aid went to India from 1947 through 2010, nearly all of it in the form of economic grants and loans, more than half as food aid. In 2007, in response to several years of rapid Indian economic expansion and New Delhi's new status as a donor government, the State Department announced a 35\% reduction in assistance programs for India. The bulk of the cuts came from development assistance and food aid programs. Another smaller decrease came in 2008 "in recognition of the continuing growth of the Indian economy and the ability of the government to fund more" development programs. Under the Obama Administration, however, increases in Global Health and Child Survival funds, along with some added Development Assistance, have reverted aid amounts to their previous levels. ${ }^{381}$ Table 1 shows U.S. foreign assistance categories and figures for FY2001-FY2012.

According to the U.S. Agency for International Development (USAID), India has the world's largest concentration of people living in poverty (more than 700 million earning less than $\$ 2$ per

\footnotetext{
376 “Indian Prime Minister Denounces Abortion of Females," New York Times, April 29, 2008; census data at http://www.censusindia.net/t_00_004.html.

${ }^{377}$ Cited in "India Loses 10m Female Births," BBC News, Jan. 9, 2006. Another study found that sex-selective abortions of females "increased substantially" in India from 1990-2005, especially for pregnancies after a first-born girl. The incidence was "much greater" for mothers with ten or more years of education and in wealthier as compared to poorer households (Prabhat Jha, et al., "Trends in Selective Abortions of Girls in India," Lancet (London), May 2011).

378 "Sex-Selective Abortions on the Rise in India Among Couples Without Boys," Washington Post, May 24, 2011.

${ }^{379}$ See http://www.state.gov/documents/organization/160058.pdf.

380 “The World's Most Dangerous Countries for Women," Reuters, June 15, 2011.

${ }^{381}$ See http://2001-2009.state.gov/p/sca/rls/2008/104699.htm. In 2011, New Delhi's plans to establish its own aid agency have many observers questioning the need for further foreign assistance to India (see "Aid 2.0," Economist (London), August 13, 2011).
} 
day). USAID and economic-related State Department programs in India, budgeted nearly $\$ 120$ million in FY2010, concentrate on five areas: economic growth; health; disaster management; energy and environment; and opportunity and equity. ${ }^{382}$

The United States has provided about $\$ 175$ million in military assistance to India since 1947, more than $90 \%$ of this distributed from 1962-1966. In recent years, modest security-related assistance has emphasized export control enhancements, counterterrorism and counternarcotics programs, and military training.

Table I. Direct U.S.Assistance to India, FY200 I-FY20 I I

(in millions of dollars)

\begin{tabular}{lrrrrrrrr}
\hline $\begin{array}{l}\text { Program } \\
\text { or } \\
\text { Account }\end{array}$ & $\begin{array}{r}\text { FY200I- } \\
\text { FY2005 }\end{array}$ & \multicolumn{1}{c}{ FY2006 } & FY2007 & FY2008 & FY2009 & FY2010 & $\begin{array}{r}\text { FY20II } \\
\text { (est.) }\end{array}$ & $\begin{array}{c}\text { FY2012 } \\
\text { (req.) }\end{array}$ \\
\hline CSH/GHCS & 214.7 & 52.8 & 53.4 & 66.0 & 76.0 & 87.2 & 87.4 & 105.0 \\
DA & 139.9 & 19.7 & 15.7 & 16.6 & 11.0 & 31.3 & 26.5 & 31.0 \\
ESF & 52.3 & 5.0 & 4.9 & - & - & - & - & - \\
IMET & 5.4 & 1.3 & 1.5 & 1.3 & 1.4 & 1.3 & 1.4 & 1.4 \\
NADR & 7.7 & 2.7 & 1.1 & 1.7 & 1.7 & 3.2 & 5.2 & 5.2 \\
PEPFAR & 47.0 & 29.6 & 29.9 & 29.8 & 30.5 & 27.0 & 30.0 & 30.0 \\
Subtotal & 467.0 & 111.1 & 106.5 & 115.4 & 120.6 & 150.0 & 150.5 & 172.6 \\
Food Aid* & 107.3 & 30.7 & 31.0 & 13.5 & 13.5 & 3.7 & 4.0 & 4.0 \\
Total & $\mathbf{5 7 4 . 3}$ & $\mathbf{1 4 1 . 8}$ & $\mathbf{1 3 7 . 5}$ & $\mathbf{1 2 8 . 9}$ & $\mathbf{1 3 4 . 1}$ & $\mathbf{1 5 3 . 7}$ & $\mathbf{1 5 4 . 5}$ & $\mathbf{1 7 6 . 6}$ \\
\hline
\end{tabular}

Sources: U.S. Departments of State and Agriculture; U.S. Agency for International Development. FY20II figures are estimates; FY20I 2 amounts are requested. Columns may not add up due to rounding.

Abbreviations:

CSH: Child Survival and Health (Global Health and Child Survival, or GHCS, from FY20I0)

DA: Development Assistance

ESF: Economic Support Fund

IMET: International Military Education and Training

NADR: Nonproliferation, Anti-Terrorism, Demining, and Related (mainly export control assistance, but includes anti-terrorism assistance for FY2007)

PEPFAR: President's Emergency Plan for AIDS Relief

* P.L. 480 Title II (grants), Section 416(b) of the Agricultural Act of 1949, as amended (surplus donations), and Food for Progress. Food aid totals do not include freight costs.

\footnotetext{
${ }^{382}$ See http://www.usaid.gov/in/about_usaid/overview.htm.
} 
Figure 4. Map of India

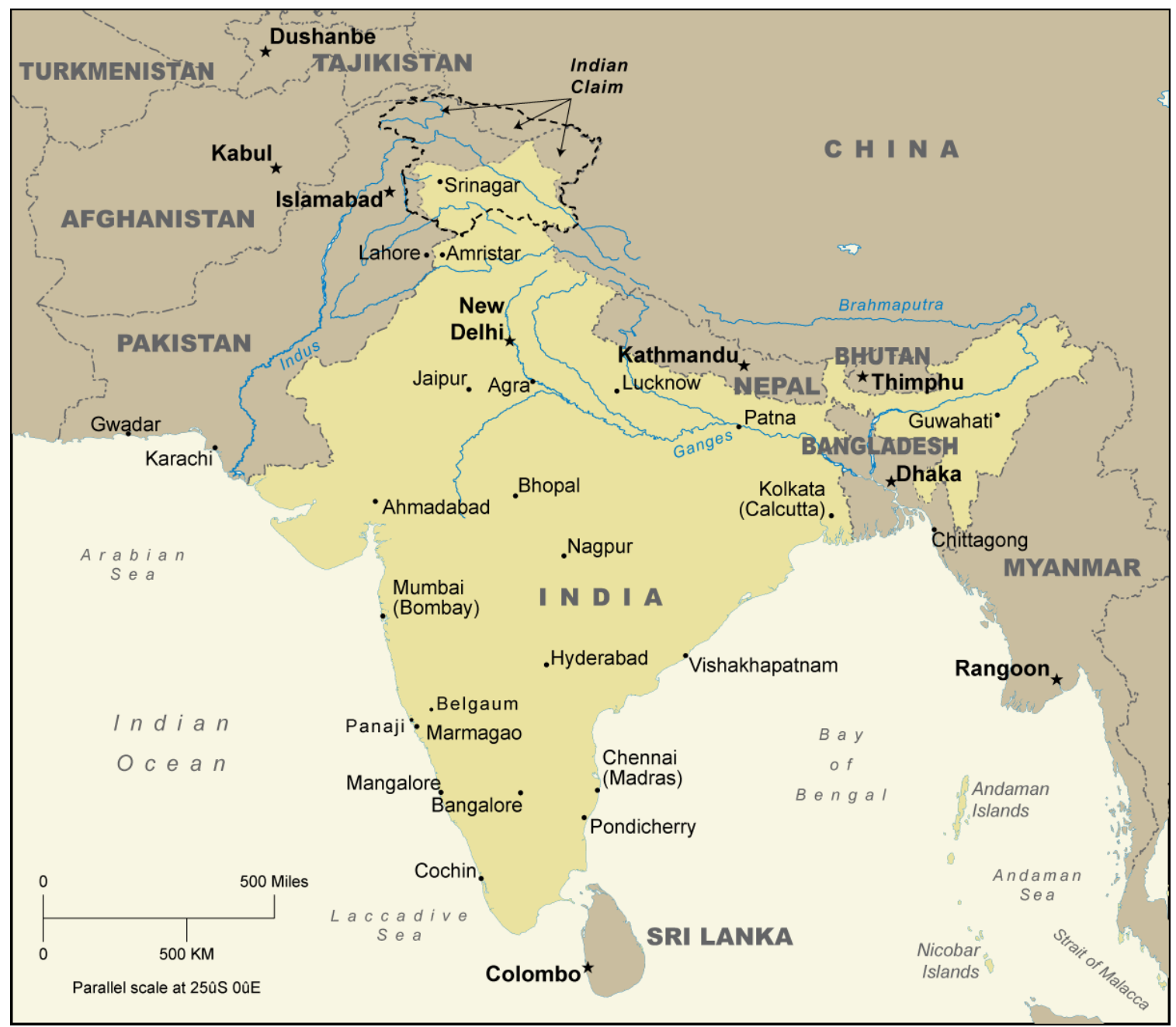

Source: Map Resources. Adapted by CRS. ( I I/20 I0)

\section{Author Contact Information}

K. Alan Kronstadt, Coordinator Specialist in South Asian Affairs akronstadt@crs.loc.gov, 7-5415

Paul K. Kerr

Analyst in Nonproliferation pkerr@crs.loc.gov, 7-8693
Michael F. Martin

Specialist in Asian Affairs

mfmartin@crs.loc.gov, 7-2199

Bruce Vaughn

Specialist in Asian Affairs

bvaughn@crs.loc.gov, 7-3144 